\title{
Analysis of International Commodity Shipping Data and the Shipment of NORM to the United States
}

\author{
JE Baciak \\ GA Sandness \\ $\mathrm{JH}$ Ely \\ SM Robinson \\ JE Schweppe
}

October 2011

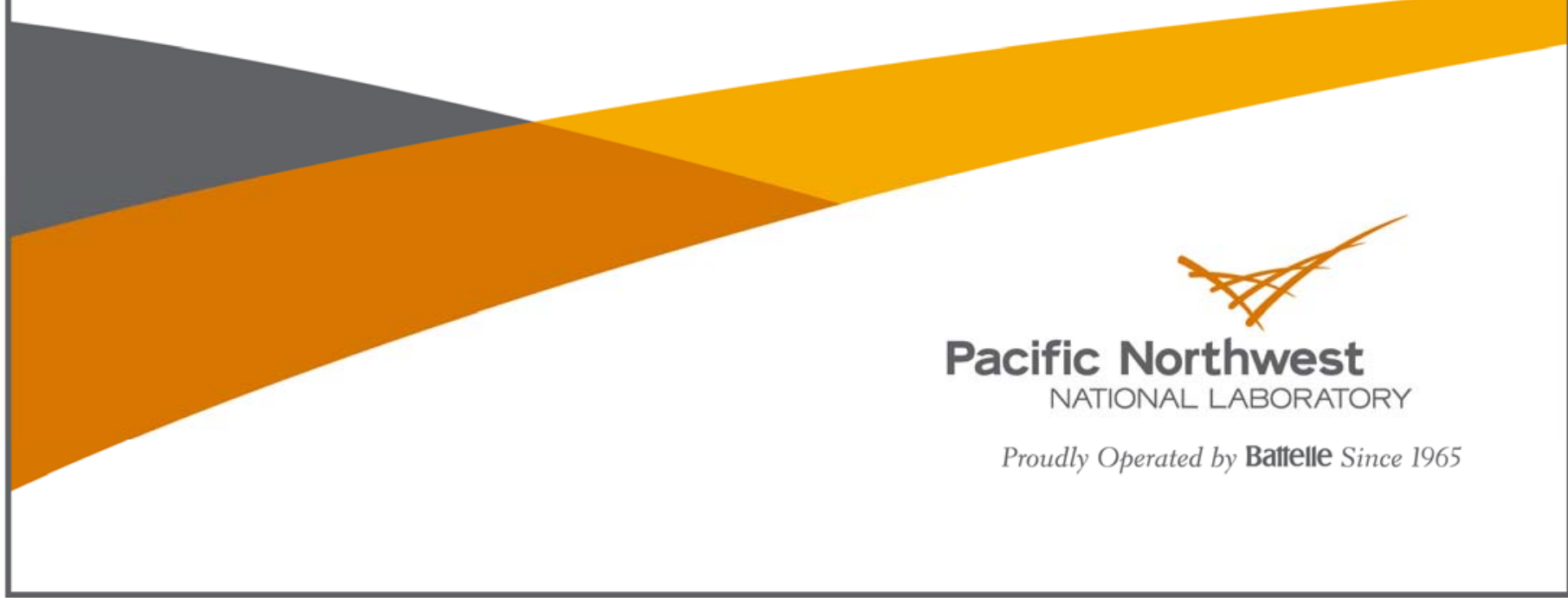




\title{
DISCLAIMER
}

This report was prepared as an account of work sponsored by an agency of the United States Government. Neither the United States Government nor any agency thereof, nor Battelle Memorial Institute, nor any of their employees, makes any warranty, express or implied, or assumes any legal liability or responsibility for the accuracy, completeness, or usefulness of any information, apparatus, product, or process disclosed, or represents that its use would not infringe privately owned rights. Reference herein to any specific commercial product, process, or service by trade name, trademark, manufacturer, or otherwise does not necessarily constitute or imply its endorsement, recommendation, or favoring by the United States Government or any agency thereof, or Battelle Memorial Institute. The views and opinions of authors expressed herein do not necessarily state or reflect those of the United States Government or any agency thereof.

\author{
PACIFIC NORTHWEST NATIONAL LABORATORY \\ operated by \\ BATTELLE \\ for the \\ UNITED STATES DEPARTMENT OF ENERGY \\ under Contract DE-AC05-76RL01830
}

Printed in the United States of America
Available to DOE and DOE contractors from the Office of Scientific and Technical Information, P.O. Box 62, Oak Ridge, TN 37831-0062; ph: (865) 576-8401 fax: $(865) 576-5728$
email: reports@adonis.osti.gov
Available to the public from the National Technical Information Service 5301 Shawnee Rd., Alexandria, VA 22312 ph: (800) 553-NTIS (6847) email: orders $a$ ntis.gov $<$ http://www.ntis.gov/about/form.aspx> Online ordering: http://www.ntis.gov




\title{
Analysis of International Commodity Shipping Data and the Shipment of NORM to the United States
}

\author{
JE Baciak \\ GA Sandness \\ JH Ely \\ SM Robinson \\ JE Schweppe
}

October 2011

Prepared for

the U.S. Department of Energy

under Contract DE-AC05-76RL01830

Pacific Northwest National Laboratory

Richland, Washington 99352 

PNNL-21088

\section{Abstract}

The detection of smuggled special nuclear material (SNM) and radiation dispersion devices (RDDs) into the United States (US) via intermodal cargo container (IMCC) remains a challenge in radiation detection, due in large part to the variability of cargo in an individual container and its impact on shielding sources from detection. Thus, it is important to understand how containerized cargo is shipped to the US, from which countries we receive different shipments, and to understand how naturally-occurring radioactive material (NORM) is shipped and can impact our capabilities to detect sources that may be used in potential weapons of mass destruction terrorism scenarios.

As part of the Spreader Bar Radiation Detector project, PNNL analyzed US import data shipped through US ports collected over the 12 months of 2006 (over 4.5 million containers). Using these data, we extracted a variety of distributions of interest to modelers and developers of active and passive detection systems used to "scan” IMCCs for potential contraband. Analysis of all containers can provide a wealth of information. More importantly, the availability of the data on all containers makes it possible to analyze the database to determine which general commodities are shipped overseas in IMCCs more frequently. This report expands on some of the analysis presented in an earlier report from LLNL, by investigating the foreign port distribution of commodities shipped to the US. 


\section{Executive Summary}

As part of the Spreader Bar Radiation Detector project, PNNL analyzed US import data collected over the 12 months of 2006 on containers shipped through US ports-over 4.5 million containers. Using these data, we extracted a variety of distributions of interest to modelers and developers of active and passive detection systems used to "scan" IMCCs for potential contraband. This report expands on some of the analysis presented in an earlier report from LLNL by investigating the foreign port distribution of commodities shipped to the US.

The majority of containers shipped to the United States are 40 -ft containers ( 70\%); about 25\% are 20-ft; and about $3.6 \%$ are 45 -ft containers. A small fraction $(<1 \%)$ of containers are of other, more specialized sizes, and very few ports actually ship these unique size containers (a full distribution for all foreign ports is shown in Appendix A). The primary foreign ports that ship the largest numbers of each container size are shown in the table below. Given that 45 -ft containers comprise 1 of out every 27 containers shipped to the US, and considering the foreign ports from which they are shipped, they should not be ignored in screening; further testing and analysis of radiation measurements for national security with this size container is warranted.

Table 1: Summary of Top 10 International Ports for the Three Major Container Sizes Shipped to the US

\begin{tabular}{|c|c|c|c|c|c|c|c|c|c|}
\hline Rank & Port & 20-ft Con & $\begin{array}{l}\text { ainers } \\
\text { \% of } \\
\text { Total }\end{array}$ & Port & 40-ft Con & $\begin{array}{l}\text { ainers } \\
\text { \% of } \\
\text { Total }\end{array}$ & Port & 45-ft Cor & $\begin{array}{l}\text { ainers } \\
\% \text { of } \\
\text { Total }\end{array}$ \\
\hline 1 & Shanghai & 159,507 & 8.60 & Yantian & 778,866 & 15.25 & Yantian & 75,824 & 28.94 \\
\hline 2 & Busan & 143,284 & 7.72 & Shanghai & 594,462 & 11.64 & Hong Kong & 33,541 & 12.80 \\
\hline 3 & Kaoshiung & 128,149 & 6.91 & Hong Kong & 417,513 & 8.17 & Shanghai & 26,933 & 10.28 \\
\hline 4 & Hong Kong & 94,618 & 5.10 & Busan & 348,586 & 6.82 & PTO Cortes & 17,545 & 6.70 \\
\hline 5 & Singapore & 71,095 & 3.83 & Kaoshiung & 317,897 & 6.22 & San Juan & 16,443 & 6.28 \\
\hline 6 & Yantian & 69,585 & 3.75 & Ningpo & 164,551 & 3.22 & Kaoshiung & 16,344 & 6.24 \\
\hline 7 & Freeport & 55,450 & 2.99 & Bremerhaven & 154,928 & 3.03 & Singapore & 9,018 & 3.48 \\
\hline 8 & Antwerp & 52,231 & 2.82 & Singapore & 146,296 & 2.86 & Rotterdam & 6,549 & 2.50 \\
\hline 9 & Santos & 48,775 & 2.63 & Rotterdam & 123,913 & 2.43 & Xiamen & 6,115 & 2.33 \\
\hline 10 & Qingdao & 47,773 & 2.58 & Qingdao & 103,273 & 2.02 & STO Tomas & 5,613 & 2.14 \\
\hline
\end{tabular}

Analysis of all containers can provide a wealth of information. Access to the database makes it possible to determine which general commodities are shipped overseas in IMCCs more frequently. Commodities are generally shipped with a 4- or 6-digit HS code that describes the commodity. These codes can be grouped by a collapsed 2-digit HS Code that represents the commodities. One can generalize this 
shipping data into approximately 16 categories that span the range of commodities. This was performed by collapsing the two-digit codes into general categories specified by Foreign Trade On-Line Corporation. These data are shown in Table 2 below. It should be noted that HS codes 90-97 are generally referred to as a 'miscellaneous' category, but we did not collapse the HS codes in this major category because these commodities represent a large fraction of the total number of containers shipped to the US (particularly 40- and 45-ft containers), and the commodities grouped therein are quite different from one another. The breakdown for all 97 HS codes is shown in Appendix B of this report.

Table 2: Shipping Container Data Arranged by Major HS Code Categories

\begin{tabular}{|c|c|c|c|c|c|c|c|}
\hline $\begin{array}{c}\text { HS } \\
\text { Code } \\
\text { Range }\end{array}$ & Description & $\begin{array}{c}20-\mathrm{ft} \\
\text { Containers }\end{array}$ & Percent & $\begin{array}{c}\text { 40-ft } \\
\text { Containers }\end{array}$ & Percent & $\begin{array}{c}\text { 45-ft } \\
\text { Containers }\end{array}$ & Percent \\
\hline 00 & Household Goods & 49,895 & 2.69 & 199,852 & 3.91 & 12,032 & 4.59 \\
\hline 01-05 & Animal and Animal Products & 45,524 & 2.45 & 104,827 & 2.05 & 268 & 0.10 \\
\hline 06-15 & Vegetable Products & 128,119 & 6.91 & 227,331 & 4.45 & 964 & 0.37 \\
\hline $16-24$ & Foodstuffs & 182,724 & 9.85 & 280,804 & 5.50 & 3750 & 1.43 \\
\hline $25-27$ & Mineral Products & 74,358 & 4.01 & 16,114 & 0.32 & 138 & 0.05 \\
\hline $28-38$ & Chemical \& Allied Industries & 163,034 & 8.79 & 128,406 & 2.51 & 5162 & 1.97 \\
\hline $39-40$ & Plastics \& Rubbers & 128,262 & 6.91 & 455,844 & 8.92 & 13,948 & 5.32 \\
\hline $41-43$ & $\begin{array}{l}\text { Raw Hides, Skins, Leather \& } \\
\text { Furs }\end{array}$ & 11,085 & 0.60 & 83,440 & 1.63 & 7767 & 2.96 \\
\hline $44-49$ & Wood \& Wood Products & 120,774 & 6.51 & 391,535 & 7.66 & 10,176 & 3.88 \\
\hline $50-63$ & Textiles \& Clothing & 67,524 & 3.64 & 382,513 & 7.49 & 51,426 & 19.63 \\
\hline $64-67$ & Footwear \& Headgear & 15,108 & 0.81 & 108,316 & 2.12 & 18,999 & 7.25 \\
\hline $68-71$ & Stone \& Glass & 238,465 & 12.85 & 156,979 & 3.07 & 5203 & 1.99 \\
\hline $72-83$ & Metals & 299,302 & 16.13 & 316,307 & 6.19 & 18,730 & 7.15 \\
\hline $84-85$ & Machinery \& Electrical & 174,963 & 9.43 & 801,411 & 15.69 & 22,395 & 8.55 \\
\hline $86-89$ & Transportation Products & 80,965 & 4.36 & 293,234 & 5.74 & 12,384 & 4.73 \\
\hline 90 & $\begin{array}{l}\text { Photograph and Medical } \\
\text { Instruments }\end{array}$ & 10,437 & 0.56 & 50,093 & 0.98 & 4898 & 1.87 \\
\hline 91 & Clocks \& Watches & 684 & 0.04 & 4905 & 0.10 & 566 & 0.22 \\
\hline 92 & Musical Instruments & 1566 & 0.08 & 8786 & 0.17 & 478 & 0.18 \\
\hline 93 & Arms \& Ammunition & 1068 & 0.06 & 1109 & 0.02 & 8 & 0.00 \\
\hline 94 & Furniture & 31,576 & 1.70 & 816,169 & 15.98 & 38,074 & 14.53 \\
\hline 95 & $\begin{array}{l}\text { Toys, Games \& Sports } \\
\text { Equipment }\end{array}$ & 25,360 & 1.37 & 255,781 & 5.01 & 33,013 & 12.60 \\
\hline
\end{tabular}




\begin{tabular}{|l|l|r|r|r|r|r|r|}
\hline $\begin{array}{c}\text { HS } \\
\text { Code } \\
\text { Range }\end{array}$ & \multicolumn{1}{|c|}{$\begin{array}{c}\text { Description } \\
\text { Containers }\end{array}$} & $\begin{array}{c}\text { Pe-ft } \\
\text { Percent }\end{array}$ & $\begin{array}{c}\text { 45-ft } \\
\text { Containers }\end{array}$ & $\begin{array}{c}\text { Percent } \\
\text { Containers }\end{array}$ & Percent \\
\hline 96 & Manufactured Articles & 3682 & 0.20 & 20,819 & 0.41 & 1325 & 0.51 \\
\hline 97 & Works of Art \& Antiques & 766 & 0.04 & 4113 & 0.08 & 268 & 0.10 \\
\hline
\end{tabular}

This work discusses the example port of Singapore. Of all the international ports, Singapore shipped the sixth-largest volume of containers to the US in 2006, and thus provides an excellent case-study in understanding variability of shipping from major international ports. Table 3 consolidates the commodity data for Singapore, and can be compared with Table 2 to examine major differences in commodities shipped from Singapore with respect to all other international ports. In general, Singapore shipped more vegetable products, clothing, electronics (mostly in the form of televisions and computer parts), plastic and rubber products than a typical foreign port. In 2006, Singapore was also the main port through which uranium ore was shipped to the US. Additionally, Singapore shipped less than the average number of containers with stone and glass materials, base metals, and toys. Further, Singapore shipped a slightly larger percentage (approximately 4\%) of 45 -ft containers than other ports. A specific breakdown of commodities shipped to the US through Singapore is located in Appendix C.

Table 3: Shipping Container Data for Commodities from Singapore

\begin{tabular}{|c|c|c|c|c|c|c|c|}
\hline $\begin{array}{c}\text { HS } \\
\text { Code } \\
\text { Range }\end{array}$ & Description & $\begin{array}{c}\text { 20-ft } \\
\text { Containers }\end{array}$ & Percent & $\begin{array}{c}40-\mathrm{ft} \\
\text { Containers }\end{array}$ & Percent & $\begin{array}{c}\text { 45-ft } \\
\text { Containers }\end{array}$ & Percent \\
\hline 00 & Household Goods & 1513 & 2.13 & 6981 & 4.77 & 475 & 5.22 \\
\hline 01-05 & $\begin{array}{l}\text { Animal and Animal } \\
\text { Products }\end{array}$ & 1114 & 1.57 & 7390 & 5.05 & 0 & 0.00 \\
\hline 06-15 & Vegetable Products & 10,201 & 14.35 & 1642 & 1.12 & 26 & 0.29 \\
\hline $16-24$ & Foodstuffs & 6756 & 9.51 & 2740 & 1.87 & 3 & 0.03 \\
\hline $25-27$ & Mineral Products & 2279 & 3.21 & 67 & 0.05 & 0 & 0.00 \\
\hline $28-38$ & $\begin{array}{l}\text { Chemical \& Allied } \\
\text { Industries }\end{array}$ & 2833 & 3.99 & 1588 & 1.09 & 12 & 0.13 \\
\hline $39-40$ & Plastics \& Rubbers & 11,823 & 16.64 & 10,465 & 7.15 & 2014 & 22.12 \\
\hline $41-43$ & $\begin{array}{l}\text { Raw Hides, Skins, } \\
\text { Leather \& Furs }\end{array}$ & 384 & 0.54 & 693 & 0.47 & 30 & 0.33 \\
\hline $44-49$ & Wood \& Wood Products & 2557 & 3.60 & 8244 & 5.64 & 198 & 2.17 \\
\hline $50-63$ & Textiles \& Clothing & 7140 & 10.05 & 32,092 & 21.94 & 2740 & 30.09 \\
\hline $64-67$ & Footwear \& Headgear & 922 & 1.30 & 2564 & 1.75 & 338 & 3.71 \\
\hline $68-71$ & Stone \& Glass & 5011 & 7.05 & 3709 & 2.54 & 58 & 0.64 \\
\hline $72-83$ & Metals & 7911 & 11.13 & 3822 & 2.61 & 187 & 2.05 \\
\hline
\end{tabular}




\begin{tabular}{|c|c|c|c|c|c|c|c|}
\hline $\begin{array}{c}\text { HS } \\
\text { Code } \\
\text { Range }\end{array}$ & Description & $\begin{array}{c}\text { 20-ft } \\
\text { Containers }\end{array}$ & Percent & $\begin{array}{c}40-\mathrm{ft} \\
\text { Containers }\end{array}$ & Percent & $\begin{array}{c}45-\mathrm{ft} \\
\text { Containers }\end{array}$ & Percent \\
\hline $84-85$ & Machinery \& Electrical & 7599 & 10.69 & 35,195 & 24.06 & 855 & 9.39 \\
\hline $86-89$ & Transportation Products & 1388 & 1.95 & 2931 & 2.00 & 12 & 0.13 \\
\hline 90 & $\begin{array}{l}\text { Photograph and Medical } \\
\text { Instruments }\end{array}$ & 222 & 0.31 & 1672 & 1.14 & 460 & 5.05 \\
\hline 91 & Clocks \& Watches & 1 & 0.00 & 19 & 0.01 & 0 & 0.00 \\
\hline 92 & Musical Instruments & 79 & 0.11 & 944 & 0.65 & 56 & 0.62 \\
\hline 93 & Arms \& Ammunition & 0 & 0.00 & 1 & 0.00 & 0 & 0.00 \\
\hline 94 & Furniture & 808 & 1.14 & 20,893 & 14.28 & 1511 & 16.60 \\
\hline 95 & $\begin{array}{l}\text { Toys, Games \& Sports } \\
\text { Equipment }\end{array}$ & 320 & 0.45 & 1910 & 1.31 & 129 & 1.42 \\
\hline 96 & Manufactured Articles & 194 & 0.27 & 494 & 0.34 & 0 & 0.00 \\
\hline 97 & Works of Art \& Antiques & 16 & 0.02 & 208 & 0.14 & 1 & 0.01 \\
\hline
\end{tabular}

While a large amount of NORM is shipped in IMCCs, only a few specific commodities are shipped with enough frequency to present potential issues in screening IMCCs at ports that handle overseas shipping containers. The majority of containers with NORM will contain fertilizers (5,700 containers), granite (59,000 containers), or ceramic (225,000 containers) materials. Fertilizers were generally shipped in either 20 - or 40 -ft containers with equal frequency. While granite is mostly shipped in 20-ft containers, ceramic materials can be shipped in either 20 - or 40 - $\mathrm{ft}$ containers. The size of container depended on the specific use of the ceramic or porcelain material. General construction ceramics (such as floor and roofing tiles) tend to be shipped in 20 -ft containers. Consumer products made from ceramic materials (e.g., tableware, sinks, and toilets) are generally shipped in 40-ft containers. This discrepancy is due in large part to the packaging of the commodity. Consumer products are generally shipped packed in a box loaded with Styrofoam ${ }^{\mathrm{TM}}$ or other packing material to protect the product from breakage. Construction ceramic materials are generally shipped in less packing material, many times consisting of only a cardboard or wooden box. Granite is almost always shipped in a 20-ft container, due to its very high density. Thus, signatures from certain commodities containing NORM can be associated with specific container sizes. 
PNNL-21088

\section{Acronyms and Abbreviations}

HS Code

IMCC

NORM/TENORM

PIERS

RDD

RPMP

SLD

SNM

TEU

US
Harmonized System Code

Intermodal cargo container

(Technologically-enhanced) Naturally occurring radioactive material

Port Import Export Reporting Service

Radiological dispersion device

Radiation Portal Monitor Project

Second Line of Defense

Special nuclear material

Twenty-foot equivalent unit

United States 


\section{Contents}

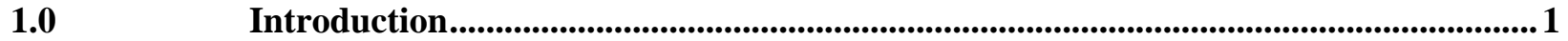

2.0 Analysis of Containerized Commodities Entering the United States .............................. 3

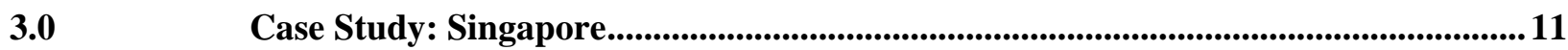

Products shipped from Singapore ............................................................................. 12

4.0 Analysis of NORM Commodities Entering the United States ..................................... 19

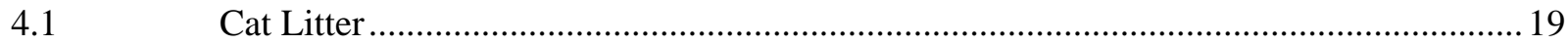

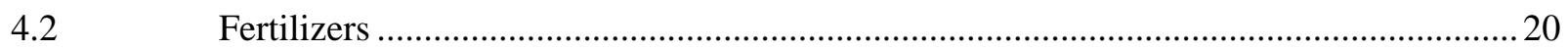

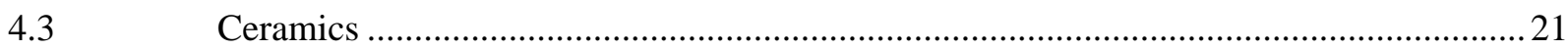

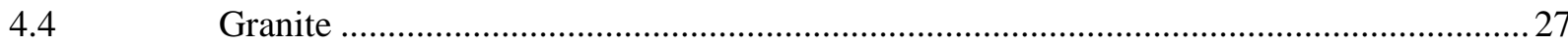

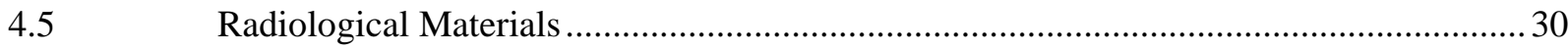

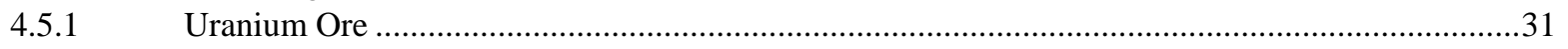

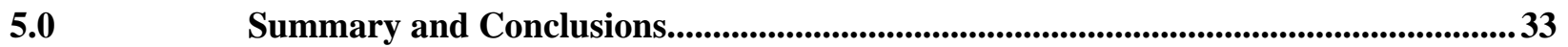

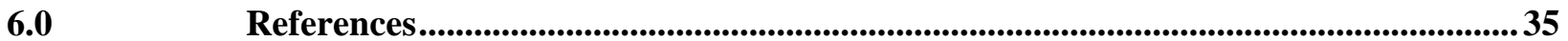

Appendix A : List of All International Ports and Number of Containers Shipped to the United

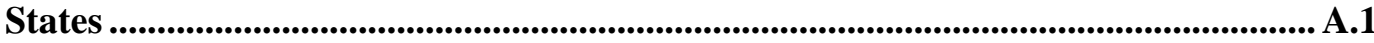

Appendix B : List of Shipping Container Distribution Based on 2-Digit Harmonized System Commodity Codes....................................................................................................................... B. 1

Appendix C : List of Shipping Container Distribution Based on 2-Digit Harmonized System Commodity Codes for IMCCs from Singapore ........................................................... C.1

Appendix D : List of Ceramic Materials Shipped to the United States .................................................. D.1 


\section{Figures}

Figure 1. Weight distribution of all containerized commodities entering the United States .5

Figure 2: Commodity distributions for 20-ft containers; (a) 35,000-40,000 lb/container and (b) 41,000-50,000 lb/container, with emphasis on several major commodities that contribute to the distribution in the specific weight range

Figure 3: Commodity distributions for 40-ft containers; (a) 0-30,000 lb/container, (b) 35,000$47,000 \mathrm{lb} /$ container, and (c) 54,000-60,000 lb/container, with emphasis on several of the major commodities that contribute to the distribution in the specific weight range

Figure 4: Container weight distribution for containers coming to the US from Singapore

Figure 5: Commodity distributions for 20-ft containers from Singapore; (a) 015,000 lb/container, (b) 30,000-42,000 lb/container and (b) 42,000-50,000 lb/container, emphasizing several of the major commodities that contribute to the distribution in the specific weight range.

Figure 6: Commodity distributions for 40-ft containers from Singapore; (a) 030,000 lb/container, (b) 35,000-47,000 lb/container and (b) 50,000-60,000 lb/container, emphasizing several of the major commodities that contribute to the distribution in the specific weight range.

Figure 7: Commodity distribution for 45-ft containers from Singapore, with emphasis on several of the major commodities that contribute to the distribution

Figure 8: Foreign ports that ship fertilizer to the US. This includes fertilizers of all compositions, including pure nitrogen-based fertilizers, which do not present a NORM challenge. This distribution also included mixed nitrogen, phosphorous, and potassium fertilizers. Note: Only ports that ship more than nine containers per year are included in the above distribution.

Figure 9: Global container weight distribution for all ceramic products

Figure 10: Foreign ports that ship ceramic products to the US in 20-ft containers. Note: Only ports with shipments in excess of 100 containers are shown.

Figure 11: Foreign ports that ship ceramic products to the US in 40-ft containers. Note: Only ports shipping more than 100 containers are shown.

Figure 12: Foreign ports that ship ceramic products to the US in 45-ft containers. Note: Only ports with shipments in excess of 20 containers are shown.

Figure 13: Container weight distribution for (a) "construction” ceramic goods, and (b) "consumer" ceramic goods 
PNNL-21088

Figure 14: Container weight distribution for granite materials.

Figure 15: Foreign port distribution of granite materials shipped in 20-ft containers. Only ports that shipped more than 50 containers in 2006 are shown.

Figure 16: Foreign port distribution of granite materials shipped in $40-\mathrm{ft}$ containers. Only ports that shipped upwards of five containers in 2006 are shown. ..................................................30

Figure 17: Foreign port distribution for containers with radiological materials (including spent

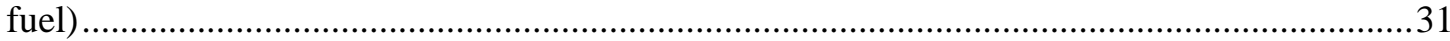

Figure 18: Foreign port distribution of containers with uranium ore..........................................32 
PNNL-21088

\section{Tables}

Table 1: Summary of Top 10 International Ports for the Three Major Container Sizes Shipped to

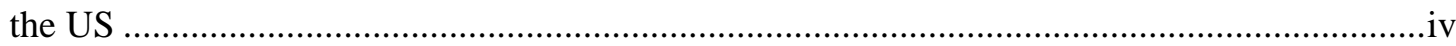

Table 2: Shipping Container Data Arranged by Major HS Code Categories ..................................v

Table 3: Shipping Container Data for Commodities from Singapore .............................................vi

Table 4: Container Size Color Coding for Graphs and Figures ....................................................

Table 5: Summary of Top 10 International Ports for the Three Major Container Sizes Shipped to

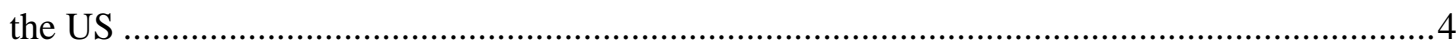

Table 6: Total Number of Containers With A Single Commodity Shipped to the US in 2006 ........4

Table 7: Weight Limitations for Standard Dry IMCC Lengths (Schumacher Cargo Logistics 2011)

Table 8: Shipping Container Data Arranged by Major HS Code Categories ..................................9

Table 9: Shipping Container Data Arranged by Major HS Code ................................................18

Table 10: Commodity Shipping Results for Bentonite (Common Mineral for Clumping Cat Litter)

Table 11: Activity Concentrations of Radioisotopes Commonly Found in Phosphate Materials....20

Table 12: Activity Concentrations of Radioisotopes Commonly Found in Granite .27 


\subsection{Introduction}

The detection of smuggled special nuclear material (SNM) and radiation dispersion devices (RDDs) into the United States (US) via intermodal cargo container (IMCC) remains a challenge in radiation detection, due in large part to the variability of cargo in an individual container and its impact on shielding sources from detection. Thus, it is important to understand how containerized cargo is shipped to the US, from which countries we receive different shipments, and to understand how naturally-occurring radioactive material (NORM) is shipped and can impact our capabilities to detect sources that may be used in potential weapons of mass destruction terrorism scenarios. To assess the amounts and types of containerized cargo being shipped to the US, PNNL analyzed US import data on cargo shipped through US ports over all 12 months of 2006. Using these data, we extracted a variety of distributions that are of interest to modelers and developers of active and passive detection systems used to "scan” IMCCs for potential contraband.

The data used in this report were obtained from Port Import Export Reporting Service (PIERS) Global Intelligence Solutions, hereinafter referred to as PIERS. ${ }^{1}$ The company collects data from more than 15 million bills of lading per year, which translates to more than 20 million shipments, with data as far back as 1950. PIERS processes these data into databases, facts, and figures, which others can then use to better understand the global trade market. With the database we obtained, we were able to better understand the dynamics of what commodities are shipped to the US, from which ports, and in what quantities. Each commodity has a specific Harmonized System (HS) Code-a numerical identifier for the commodity.

Section 2 of this report contains generalized analysis of commodity data obtained from the data set for IMCCs entering the United States. Section 3 provides Singapore as an example case study of a foreign port. This section also demonstrates the importance of understanding that different foreign ports emphasize the shipment of different specific commodities. Section 4 presents an analysis of NORM materials that are shipped from overseas ports to the US, and can serve as a guide in determining which NORM merit greater attention because they can produce false alarms in incoming overseas IMCCs. In addition, the results and analysis in this report can serve as a guide for the development of risk models for the trafficking of nuclear and radiological weapons through international shipping streams.

This report expands on some of the analysis presented in an earlier report from Lawrence Livermore National Laboratory (LLNL) (Descalle et al. 2006). One important difference is that PNNL's report analyzes the foreign port distribution, rather than the domestic. Another is that the database used in our analysis contained a full year's worth of commodity data, as opposed to the 14 highest-volume days in a calendar year, as in the LLNL report (Descalle et al. 2006). The longer the period analyzed, the less error daily variations in cargo will create. We also analyze the data based on container weight (in pounds), not twenty-foot equivalent units (TEU). However, this prevents us from examining containers that are partially full or contain multiple commodities, since the database will not indicate the specific size of the container. Thus only approximately $70 \%$ of the total commodity volume shipped to the US in 2006 was

${ }^{1}$ Piers Global Intelligence Solutions, 2 Penn Plaza East, $12^{\text {th }}$ Floor, Newark, New Jersey, USA. 
PNNL-21088

analyzed. Despite this, our analysis included over 4.5 million database entries (records) and over 7 million IMCCs.

It should be noted that this report does not include significant analysis of a variety of food items that are sometimes considered NORM due to their ${ }^{40} \mathrm{~K}$ signature (e.g., bananas and coffee). Modern cargo screening systems employ algorithms and equipment that can properly screen out these materials, and prevent them from causing unwanted false alarms. The NORM presented here generally contain isotopes of uranium, thorium, and their associated daughter products in sufficient quanitities that can potentially cause false alarms in modern systems. The PIERS database we acquired (which had been previously obtained by PNNL) had only about 12 fields out of approximately 75 potential fields that encompass a full PIERS record. Some of the other categories would have been ideal to include for a more complete study of the shipment of IMCCs to the US. These fields include information on container volume, which would have allowed us to separate containers of different heights but the same length, or potentially analyze database entries that utilized a partial container but did not specify a container size. 


\subsection{Analysis of Containerized Commodities Entering the United States}

To analyze commodities entering the United States, we used the PIERS dataset and Microsoft Access to apply queries and filters to the dataset to extract information on the number of containers, weight distribution of containers, foreign port of export, and specific commodity data. All commodity data were from calendar year 2006. All weights were converted to pounds (lb), and for database entries with more than one IMCC, we calculated the pounds per container for that entry. Weight information is rounded to the nearest $100 \mathrm{lb}$. Thus, there will be some deviation from the actual weight distributions of individual containers since we do not know the actual weights for IMCCs in these data entries. The number of containers in a single database entry varied from 1 to approximately 2000 within the 2006 PIERS dataset.

For all graphs and figures in this report, we separate 20-, 40-, and 45-ft container data and distributions, and indicate the three container sizes with distinct colors. Lines and bars in the figures throughout this report are color coded as shown in Table 4.

Table 4: Container Size Color Coding for Graphs and Figures

\begin{tabular}{|c|c|}
\hline $\begin{array}{l}\text { Container } \\
\text { Length }\end{array}$ & Color \\
\hline $20 \mathrm{ft}$ & \\
\hline $40 \mathrm{ft}$ & \\
\hline $45 \mathrm{ft}$ & \\
\hline
\end{tabular}

Table 5 shows a summary of the top foreign ports for shipping the three primary sizes of containers (20-, 40-, and 45-ft length) to the US. As can be seen, a significant number of ports appear in more than one category of shipping container. These are the major international ports that ship to the US, the majority of which are in Asia (China, Japan, South Korea, and Taiwan). Three of largest-volume shipping ports are from the European Union (Antwerp, Bremerhaven, and Rotterdam), with a couple of indicated ports from the Caribbean and South America (for larger 45-foot containers). The port of Yantian (China) clearly handles the largest number of containers that get shipped to the US (>920,000), totaling approximately $13 \%$ of all containers shipped to the US in 2006. It should also be noted that the ports listed in Table 5 handled a majority of the containers shipped to the US, with approximately $47 \%, 62 \%$, and $82 \%$ of 20 -, 40-, and 45-ft containers, respectively. 
PNNL-21088

Table 5: Summary of Top 10 International Ports for the Three Major Container Sizes Shipped to the US

\begin{tabular}{|c|c|c|c|c|c|c|c|c|c|}
\hline Rank & Port & \multicolumn{2}{|c|}{$\begin{array}{c}\text { 20-ft Containers } \\
\text { \% of } \\
\text { Number } \quad \text { Total }\end{array}$} & Port & \multicolumn{2}{|c|}{$\begin{array}{l}\text { 40-ft Containers } \\
\% \text { of } \\
\text { Number } \quad \text { Total }\end{array}$} & Port & \multicolumn{2}{|c|}{$\begin{array}{r}\text { 45-ft Containers } \\
\% \text { of } \\
\text { Number Total }\end{array}$} \\
\hline 1 & Shanghai & 159,507 & 8.60 & Yantian & 778,866 & 15.25 & Yantian & 75,824 & 28.94 \\
\hline 2 & Busan & 143,284 & 7.72 & Shanghai & 594,462 & 11.64 & Hong Kong & 33,541 & 12.80 \\
\hline 3 & Kaoshiung & 128,149 & 6.91 & Hong Kong & 417,513 & 8.17 & Shanghai & 26,933 & 10.28 \\
\hline 4 & Hong Kong & 94,618 & 5.10 & Busan & 348,586 & 6.82 & PTO Cortes & 17,545 & 6.70 \\
\hline 5 & Singapore & 71,095 & 3.83 & Kaoshiung & 317,897 & 6.22 & San Juan & 16,443 & 6.28 \\
\hline 6 & Yantian & 69,585 & 3.75 & Ningpo & 164,551 & 3.22 & Kaoshiung & 16,344 & 6.24 \\
\hline 7 & Freeport & 55,450 & 2.99 & Bremerhaven & 154,928 & 3.03 & Singapore & 9018 & 3.48 \\
\hline 8 & Antwerp & 52,231 & 2.82 & Singapore & 146,296 & 2.86 & Rotterdam & 6549 & 2.50 \\
\hline 9 & Santos & 48,775 & 2.63 & Rotterdam & 123,913 & 2.43 & Xiamen & 6115 & 2.33 \\
\hline 10 & Qingdao & 47,773 & 2.58 & Qingdao & 103,273 & 2.02 & STO Tomas & 5613 & 2.14 \\
\hline
\end{tabular}

Appendix A contains the full list of international shipping ports and the associated number of containers shipped to the US in 2006. It lists over 450 international ports in alphabetical order. Included in this appendix is a listing for other container sizes, representing approximately $0.25 \%$ of all international shipping containers (see Table 6). This category is dominated by 48- and 53-ft containers; however, several other "specialty" container sizes are grouped into this category as well.

Table 6: Total Number of Containers With A Single Commodity Shipped to the US in 2006

\begin{tabular}{lrrrr}
\hline Container Size & \multicolumn{1}{c}{$\mathbf{2 0}-\mathrm{ft}$} & \multicolumn{1}{c}{$\mathbf{4 0 - f t}$} & \multicolumn{1}{c}{ 45-ft } & \multicolumn{1}{c}{ Other } \\
\hline Total Number of Containers & $1,855,004$ & $5,108,122$ & 261,967 & 17,081 \\
Percent of Total & 25.61 & 70.53 & 3.62 & 0.24 \\
\hline
\end{tabular}

Tables 1 and 2 clearly point out that 40-ft containers are the primary IMCC in international shipping, with $20-\mathrm{ft}$ containers being secondary. However, it is interesting to note that $45-\mathrm{ft}$ containers make up a nonnegligible $3.6 \%$ of containers shipping overseas to the US, and more than $60 \%$ of these containers come from Asia. Thus, scenario modeling for the shipment of RDDs, SNM, and other explosives should consider the use of 45-ft IMCCs as a transport mechanism into the US. The use of this container size would impact radiation transport/shielding through the cargo and associated container.

A previous report contained analysis of weight distributions based on twenty-foot equivalent units (TEU), which normalized all container sizes. However, it may be more intuitive to investigate these distributions 
based on container size. This is demonstrated in Figure 1, which shows distinct distributions for the three different containers. For 20 - $\mathrm{ft}$ containers, the distribution is relatively flat below $30,000 \mathrm{lb}$, but has two peaks centered around 37,000 and 43,000 lb, respectively. The 40-ft container distribution has a large, broad peak below $30,000 \mathrm{lb}$, with a maximum around $14,000 \mathrm{lb}$. There is also a peak around 42,000 lb, and a relatively flat distribution from 50,000-57,000 lb. Forty-five-foot containers had a very broad distribution from 5000-45,000 lb/container, with a maximum near 17,500 lb.

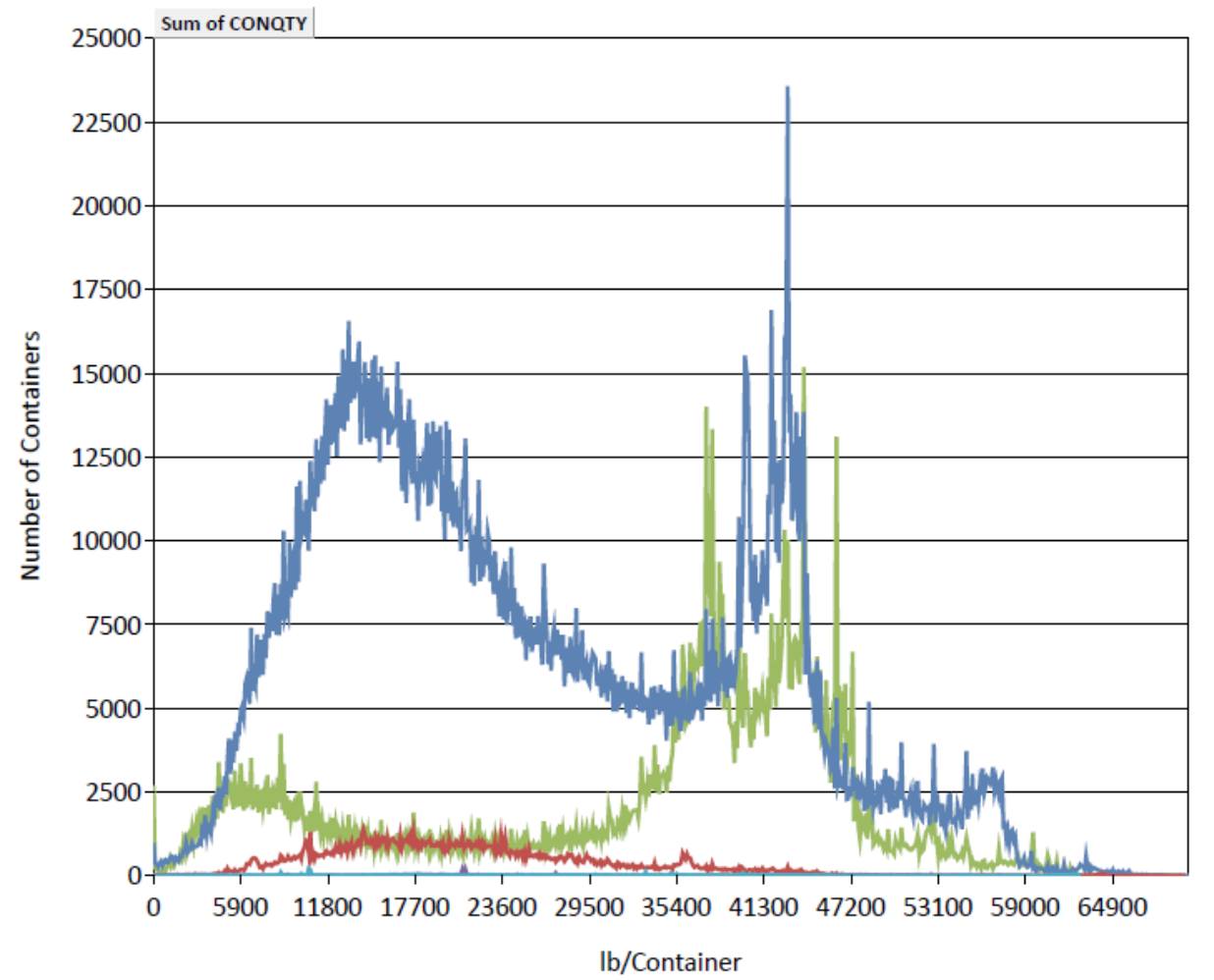

Figure 1. Weight distribution of all containerized commodities entering the United States

We analyzed each distribution to learn which commodities contribute to the distinct features in each distribution. This type of analysis affords an understanding of which commodities primarily ship in which specific container sizes. To perform this analysis, we used Microsoft Access to filter based on a shipping container size and weight range to display the commodity codes and number of containers that contribute to the particular weight range of interest. Figure 2 shows two weight ranges for 20 -ft-long containers, while Figure 3 shows three weight-range distributions for 40 -ft containers. We indicated major commodities on each of the graphs, based on commodity code descriptions that can be found on many foreign trade organization and company websites (Foreign Trade On-Line Corporation 1999).

Figure 2 demonstrates that, in general, dense materials comprise the major commodities shipped in 20-ft containers. One can also see the variation in commodities as a function of container weight for the bimodal peaks in the 20-ft distribution. For the peak centered around 37,000 lb/container, paper products, articles made of iron or steel, and automobile parts tend to be the major contributing commodities. Stones, ceramics, coffee, and other food products dominated the distribution around 45,000 lbs/container. 
PNNL-21088

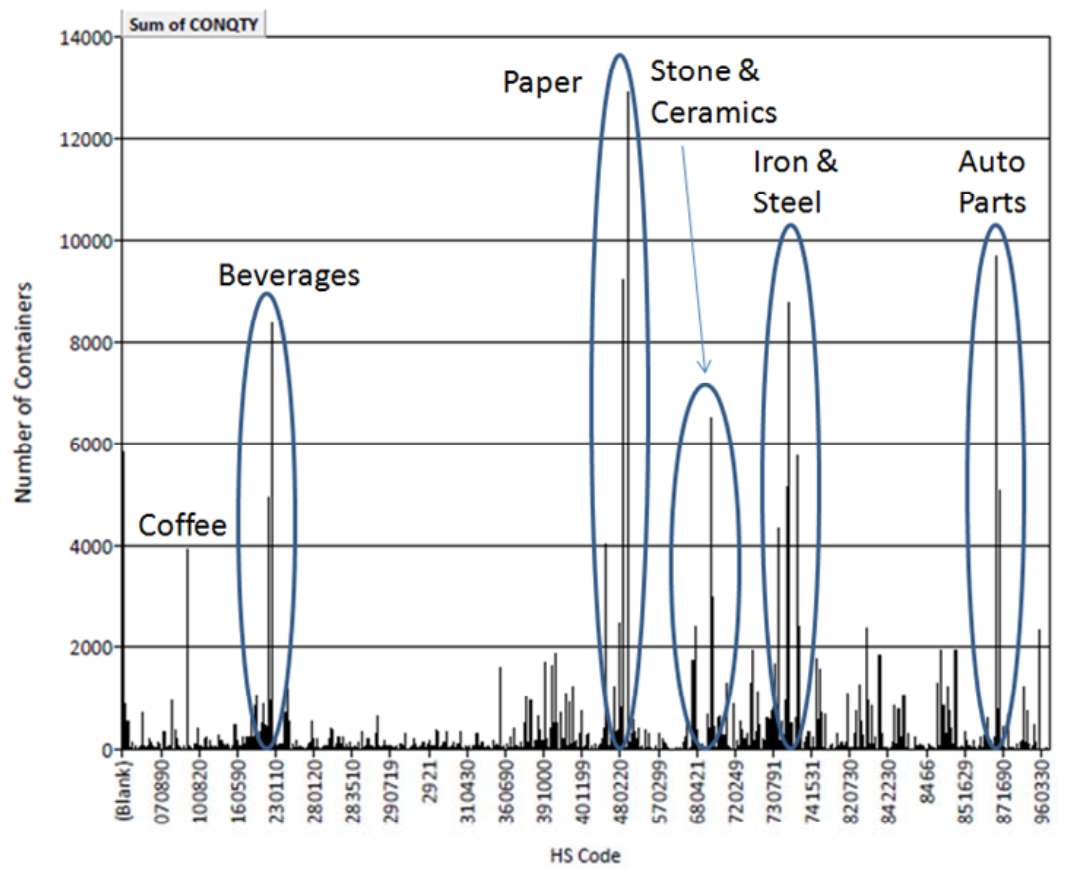

(a)

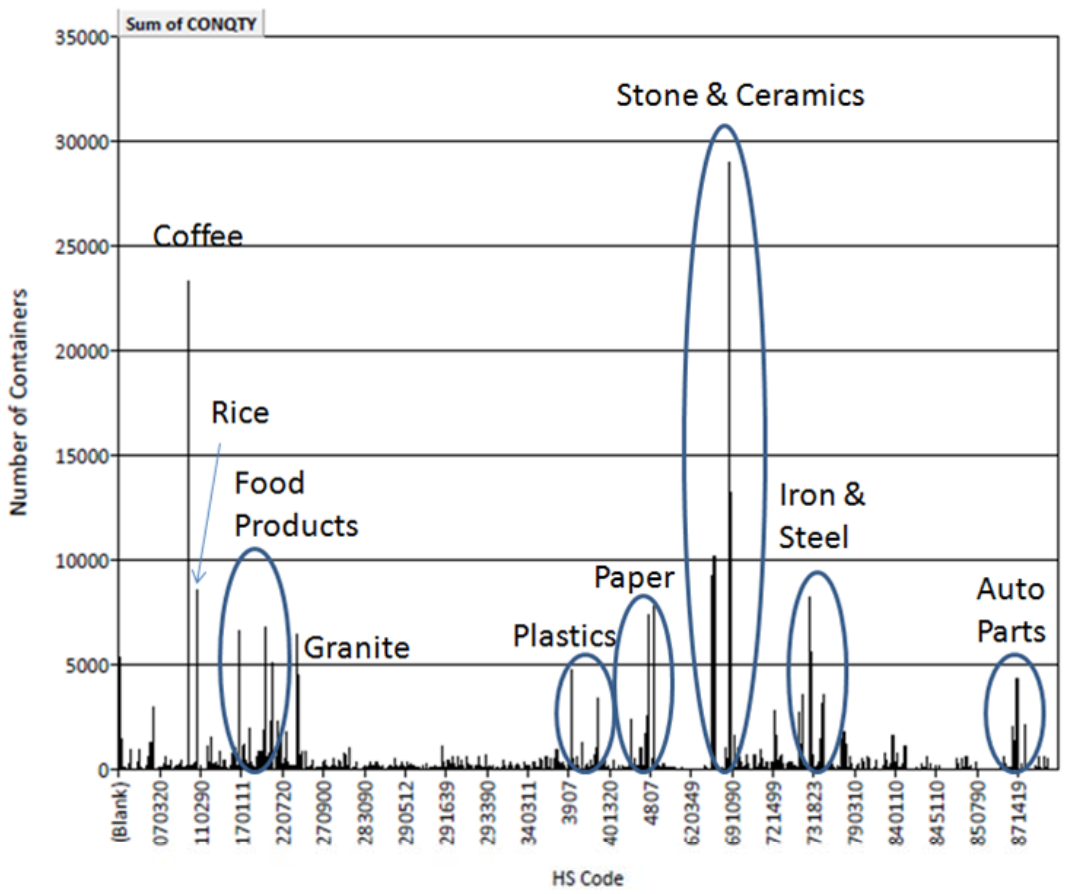

(b)

Figure 2: Commodity distributions for 20-ft containers; (a) 35,000-40,000 lb/container and (b) 41,000$50,000 \mathrm{lb} /$ container, with emphasis on several major commodities that contribute to the distribution in the specific weight range 
Figure 3 shows the commodity distributions for three ranges for $40-\mathrm{ft}$ container weights. In the weight range of up to $30,000 \mathrm{lb} /$ container, the $40-\mathrm{ft}$ container distribution is dominated by furniture, toys, tires, and clothing. Bananas, wood and paper products, plastics, and automobile parts make up a significant fraction of the commodities in the broad peak centered around 40,000 lbs/container. Finally, in the peak around 56,000 lb/container, the commodity distribution is heavily composed of beverages (more specifically, wine) and wood and paper products.

It should be noted that 40 -ft containers do tend to ship materials that are bulky, or less dense than 20 -ft containers. This is affected by the packaging of the commodities. For example, if a dense object, such as an auto part or bottle of wine, is packed in a box with a significant amount of packing material (e.g., Styrofoam ${ }^{\mathrm{TM}}$ ), its overall density is reduced; in this way these types of "heavy" items in a 40-ft container can be shipped without violating weight limitations (see Table 7 for example weight ranges for different container sizes). A specific example, ceramic materials, is described in Section 4.3.

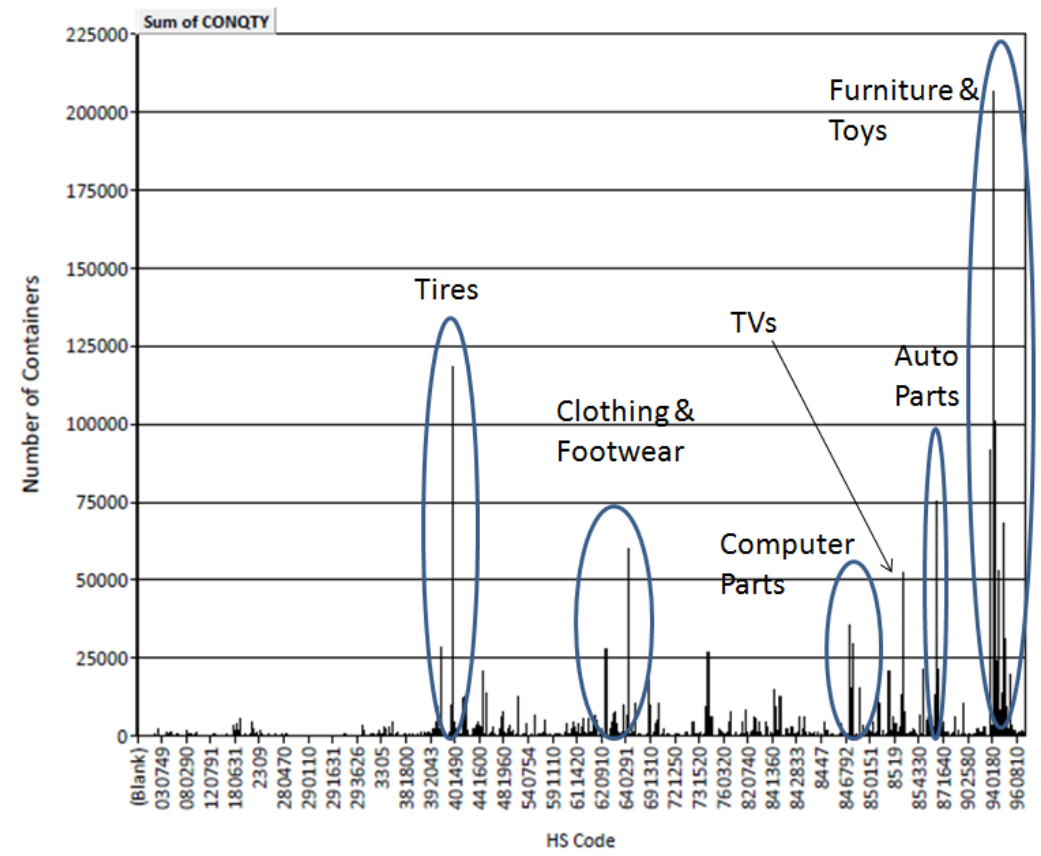

(a) 
PNNL-21088

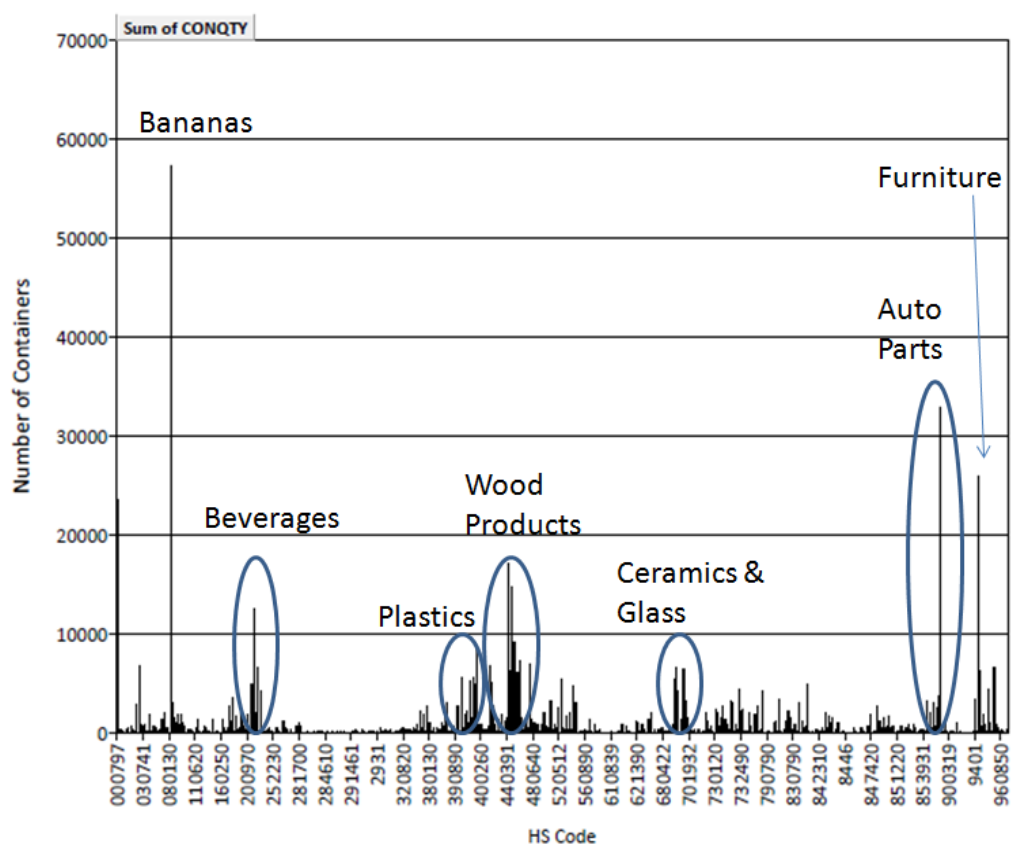

(b)

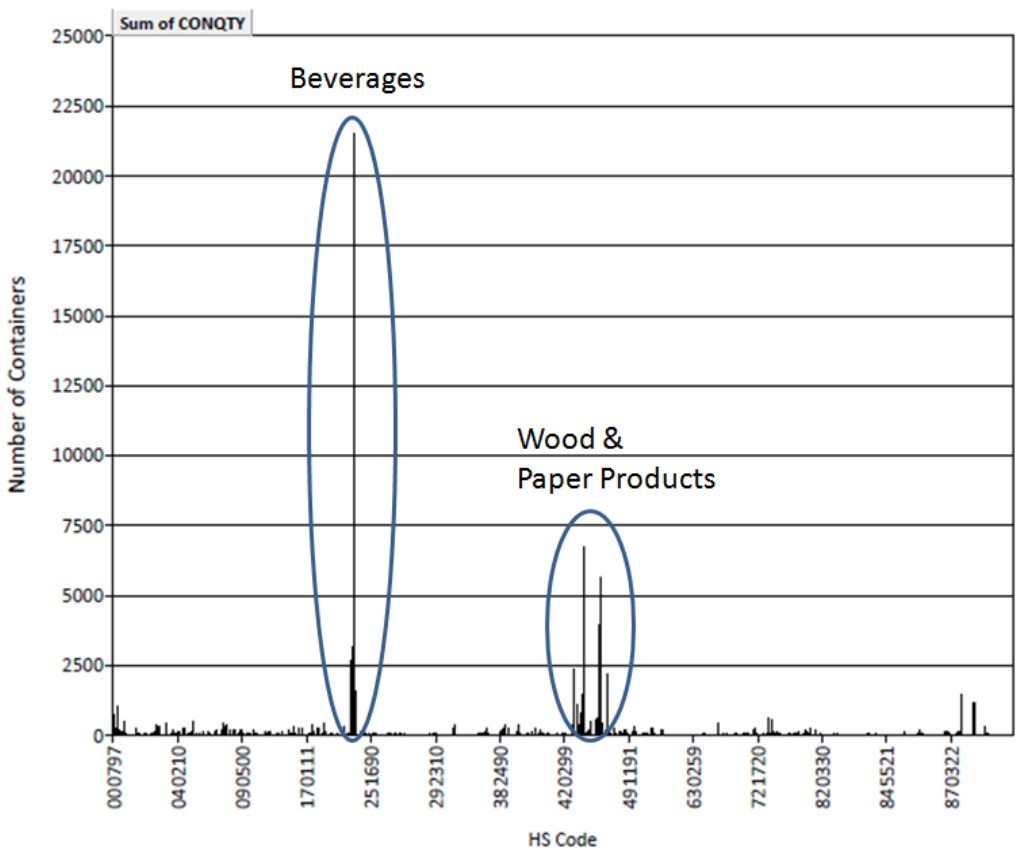

(c)

Figure 3: Commodity distributions for 40-ft containers; (a) 0-30,000 lb/container, (b) 35,000-

$47,000 \mathrm{lb} /$ container, and (c) 54,000-60,000 lb/container, with emphasis on several of the major commodities that contribute to the distribution in the specific weight range 
PNNL-21088

Table 7: Weight Limitations for Standard Dry IMCC Lengths (Schumacher Cargo Logistics 2011)

\begin{tabular}{cc}
\hline Container Length (ft) & Weight Limit Range (lb) \\
\hline 20 & $47,265-54,673$ \\
40 & $55,113-63,491$ \\
45 & $60,481-61,529$ \\
\hline
\end{tabular}

Analysis of all containers can provide a wealth of information, and in turn the database can be analyzed to determine which general commodities are shipped overseas in IMCCs more frequently. Commodities are generally shipped with a 4- or 6-digit HS code that describes the commodity. These codes can be grouped by a collapsed 2-digit HS Code that represents the commodities. One can generalize this shipping data into approximately 16 categories that spans the randge of commodities. This was performed by collapsing the two-digit codes into general categories specified by Foreign Trade On-Line Corporation (1999). These data are shown in Table 8 below. The HS codes 90-97 are generally referred to as a 'miscellaneous' category; however we chose not to collapse the HS codes in this major category, because these commodities represent a large fraction of the total number of containers shipped to the US (particularly of 40- and 45-ft containers), and the commodities shipped in them are quite different from one another. The breakdown for all 97 HS codes is shown in Appendix B of this report.

Table 8: Shipping Container Data Arranged by Major HS Code Categories

\begin{tabular}{|c|c|c|c|c|c|c|c|}
\hline $\begin{array}{c}\text { HS } \\
\text { Code } \\
\text { Range }\end{array}$ & Description & $\begin{array}{c}20-\mathrm{ft} \\
\text { Containers }\end{array}$ & Percent & $\begin{array}{c}40-\mathrm{ft} \\
\text { Containers }\end{array}$ & Percent & $\begin{array}{c}\text { 45-ft } \\
\text { Containers }\end{array}$ & Percent \\
\hline 00 & Household Goods & 49,895 & 2.69 & 199,852 & 3.91 & 12,032 & 4.59 \\
\hline 01-05 & Animal and Animal Products & 45,524 & 2.45 & 104,827 & 2.05 & 268 & 0.10 \\
\hline $06-15$ & Vegetable Products & 128,119 & 6.91 & 227,331 & 4.45 & 964 & 0.37 \\
\hline $16-24$ & Foodstuffs & 182,724 & 9.85 & 280,804 & 5.50 & 3750 & 1.43 \\
\hline $25-27$ & Mineral Products & 74,358 & 4.01 & 16,114 & 0.32 & 138 & 0.05 \\
\hline $28-38$ & Chemical \& Allied Industries & 163,034 & 8.79 & 128,406 & 2.51 & 5162 & 1.97 \\
\hline $39-40$ & Plastics \& Rubbers & 128,262 & 6.91 & 455,844 & 8.92 & 13,948 & 5.32 \\
\hline $41-43$ & $\begin{array}{l}\text { Raw Hides, Skins, Leather \& } \\
\text { Furs }\end{array}$ & 11,085 & 0.60 & 83,440 & 1.63 & 7767 & 2.96 \\
\hline $44-49$ & Wood \& Wood Products & 120,774 & 6.51 & 391,535 & 7.66 & 10,176 & 3.88 \\
\hline $50-63$ & Textiles \& Clothing & 67,524 & 3.64 & 382,513 & 7.49 & 51,426 & 19.63 \\
\hline $64-67$ & Footwear \& Headgear & 15,108 & 0.81 & 108,316 & 2.12 & 18,999 & 7.25 \\
\hline $68-71$ & Stone \& Glass & 238,465 & 12.85 & 156,979 & 3.07 & 5203 & 1.99 \\
\hline
\end{tabular}


PNNL-21088

\begin{tabular}{|c|c|c|c|c|c|c|c|}
\hline $\begin{array}{c}\text { HS } \\
\text { Code } \\
\text { Range }\end{array}$ & Description & $\begin{array}{c}\text { 20-ft } \\
\text { Containers }\end{array}$ & Percent & $\begin{array}{c}\text { 40-ft } \\
\text { Containers }\end{array}$ & Percent & $\begin{array}{c}45-\mathrm{ft} \\
\text { Containers }\end{array}$ & Percent \\
\hline $72-83$ & Metals & 299,302 & 16.13 & 316,307 & 6.19 & 18,730 & 7.15 \\
\hline $84-85$ & Machinery \& Electrical & 174,963 & 9.43 & 801,411 & 15.69 & 22,395 & 8.55 \\
\hline $86-89$ & Transportation Products & 80,965 & 4.36 & 293,234 & 5.74 & 12,384 & 4.73 \\
\hline 90 & $\begin{array}{l}\text { Photograph and Medical } \\
\text { Instruments }\end{array}$ & 10,437 & 0.56 & 50,093 & 0.98 & 4898 & 1.87 \\
\hline 91 & Clocks \& Watches & 684 & 0.04 & 4905 & 0.10 & 566 & 0.22 \\
\hline 92 & Musical Instruments & 1566 & 0.08 & 8786 & 0.17 & 478 & 0.18 \\
\hline 93 & Arms \& Ammunition & 1068 & 0.06 & 1109 & 0.02 & 8 & 0.00 \\
\hline 94 & Furniture & 31,576 & 1.70 & 816,169 & 15.98 & 38,074 & 14.53 \\
\hline 95 & $\begin{array}{l}\text { Toys, Games \& Sports } \\
\text { Equipment }\end{array}$ & 25,360 & 1.37 & 255,781 & 5.01 & 33,013 & 12.60 \\
\hline 96 & Manufactured Articles & 3682 & 0.20 & 20,819 & 0.41 & 1,325 & 0.51 \\
\hline 97 & Works of Art \& Antiques & 766 & 0.04 & 4,113 & 0.08 & 268 & 0.10 \\
\hline
\end{tabular}

The table above illustrates that different commodities tend to be shipped in different containers. For example, stone and glass materials, metals, or food products are more often shipped in 20-ft containers, while materials such as furniture, machinery and electrical equipment, and plastic and rubber materials (including tires) tend to be shipped in 40 -ft containers. Forty-five-foot containers tend to be filled with clothing, furniture, and toys. The table presented here also corroborates the data contained in Figures 2 and 3. From these results, it is easy to conclude that denser materials tend to be shipped in $20-\mathrm{ft}$ containers, but that conclusion would be somewhat misguided. One must also consider the packaging of the commodity, as relatively dense materials may be packaged in such a way as to reduce their effective density significantly, making shipping in a $40-\mathrm{ft}$ container more prudent. An example of this is ceramic materials discussed in Section 4.3 of this report. 


\subsection{Case Study: Singapore}

As an example of the information that can be extracted from the PIERS database concerning specific ports of interest, we analyzed the the shipping/commodity data for IMCCs coming from Singapore as a case study. Singapore is a large international port (sixth in total number of IMCCs shipped to the US) with little significant variation in year-to-year commodity information. Therefore, the case study described on the next several pages can be used as a guide to analysis of other major international shipping ports.

The number of containers coming from Singapore is shown in Table 1. The weight distribution of these containers is shown in Figure 4. The distribution is noticeably different from the summarized container data for all foreign ports shown in Figure 1. For 40-ft containers, there is no broad peak centered around $42,000 \mathrm{lb} /$ container. The bimodal distribution for 20 - $\mathrm{ft}$ containers is not as apparent for containers shipped from Singapore. There are also two noticeable peaks in the 45-ft container data, whereas the distribution in Figure 1 shows a relatively flat distribution. Many of the differences between the two figures can be attributed to the difference between specific commodities shipped from Singapore and those shipped from other foreign ports. Thus, to better understand shipments from major international ports and to analyze for potential risks, it is important to determine what commodities tend to be shipped from specific ports.

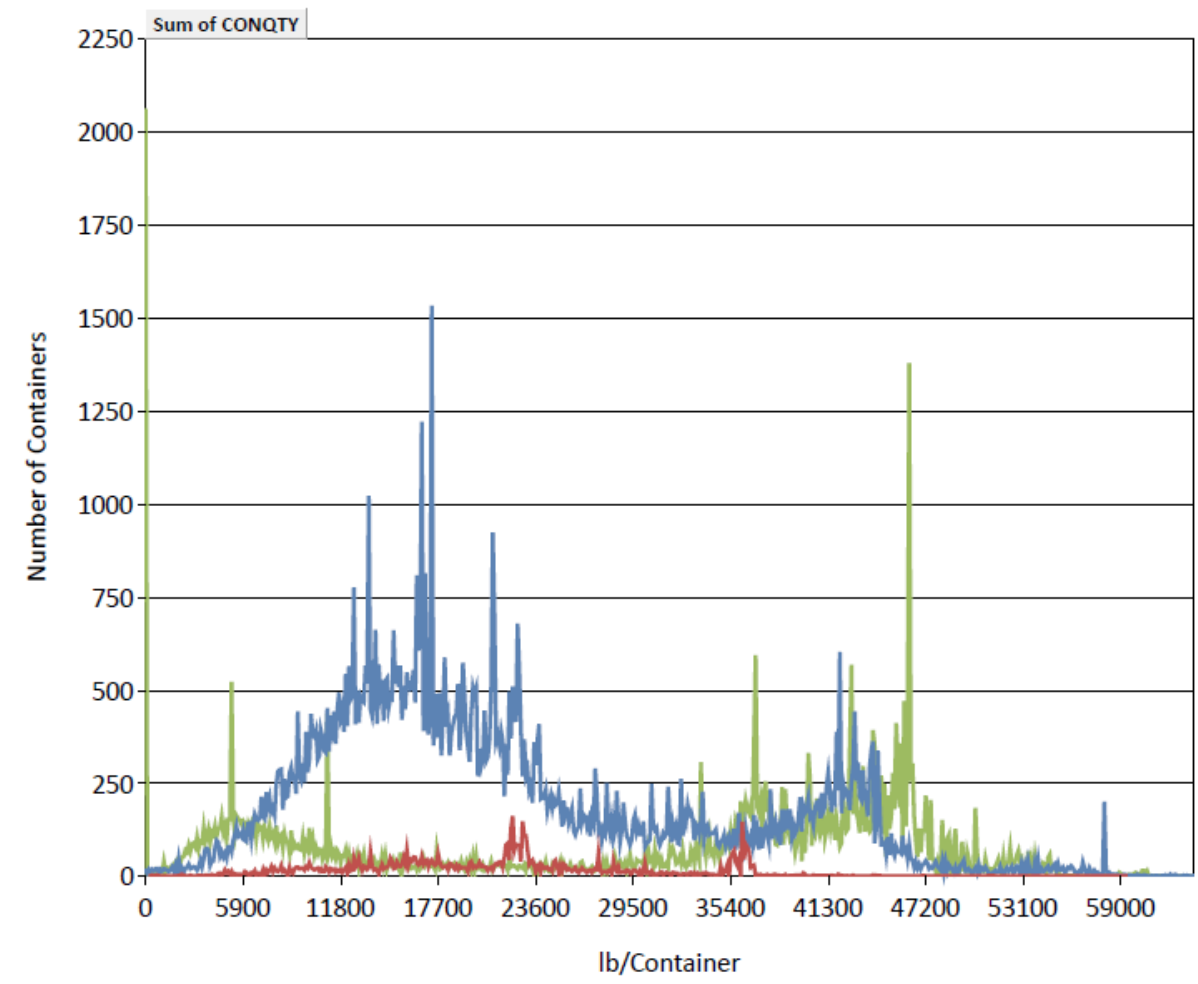

Figure 4: Container weight distribution for containers coming to the US from Singapore 
PNNL-21088

\subsection{Products shipped from Singapore}

To determine the primary commodities shipped from Singapore, we used a similar process to that presented in Section 2.0. We analyzed broad peaks and features in each distribution, and performed database queries on the resulting subsets to determine the commodities that are shipped within specific container sizes and weight ranges. This allowed us not only to determine major commodities shipped from Singapore, but also to compare the Singapore analysis with the overall shipping data from all international ports. In addition, we analyzed the 45-ft containers from Singapore, in part due to the fact that approximately $4 \%$ of containers shipped from Singapore are this size.

We used Microsoft Access to perform similar analysis and graphical representation of the Singapore data to the worldwide data shown in Section 2. Figure 5 shows the commodity distribution for 20-ft containers, with the three graphs depicting the three central features in the overall distribution, 0-15,000, 30,000-42,000, and 42,000-50,000 lbs/container, respectively. Figure 6 shows the commodity distribution for 40-ft containers, with the two graphs representing 0-30,000, 35,000-47,000, and 50,000$60,000 \mathrm{lbs} /$ container. Figure 7 shows the commodity distribution for all 45 -ft containers coming from Singapore. 
PNNL-21088

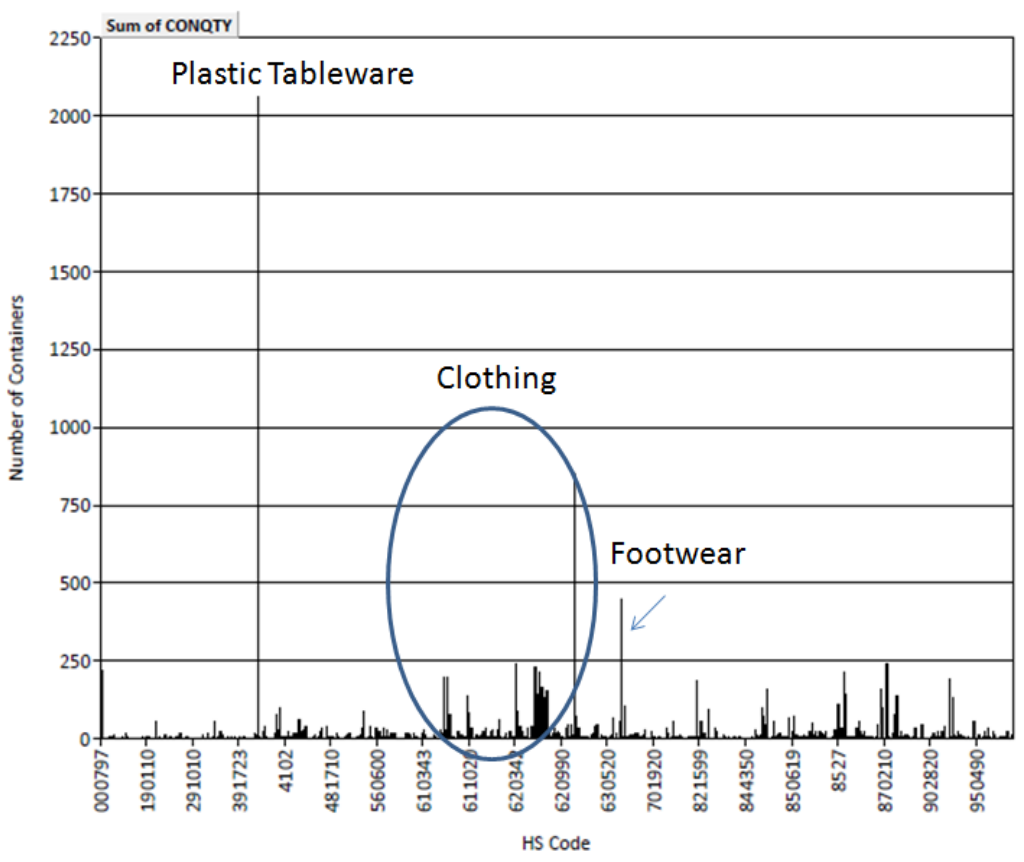

(a)

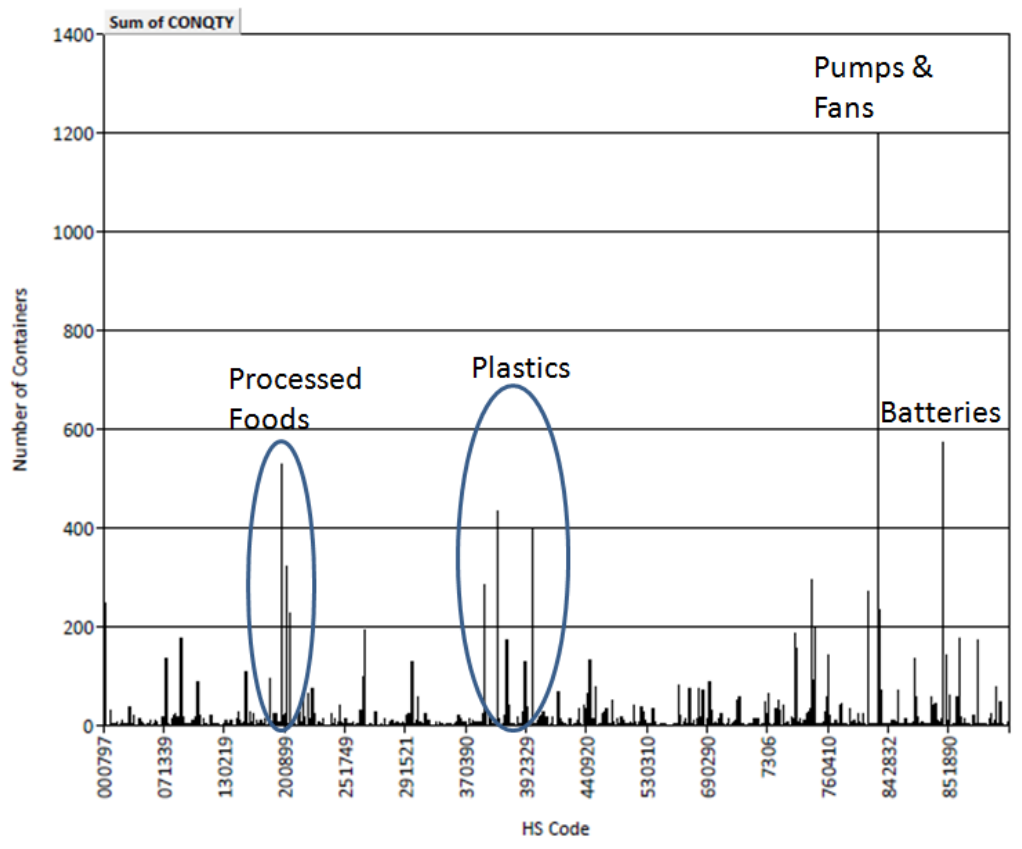

(b) 
PNNL-21088

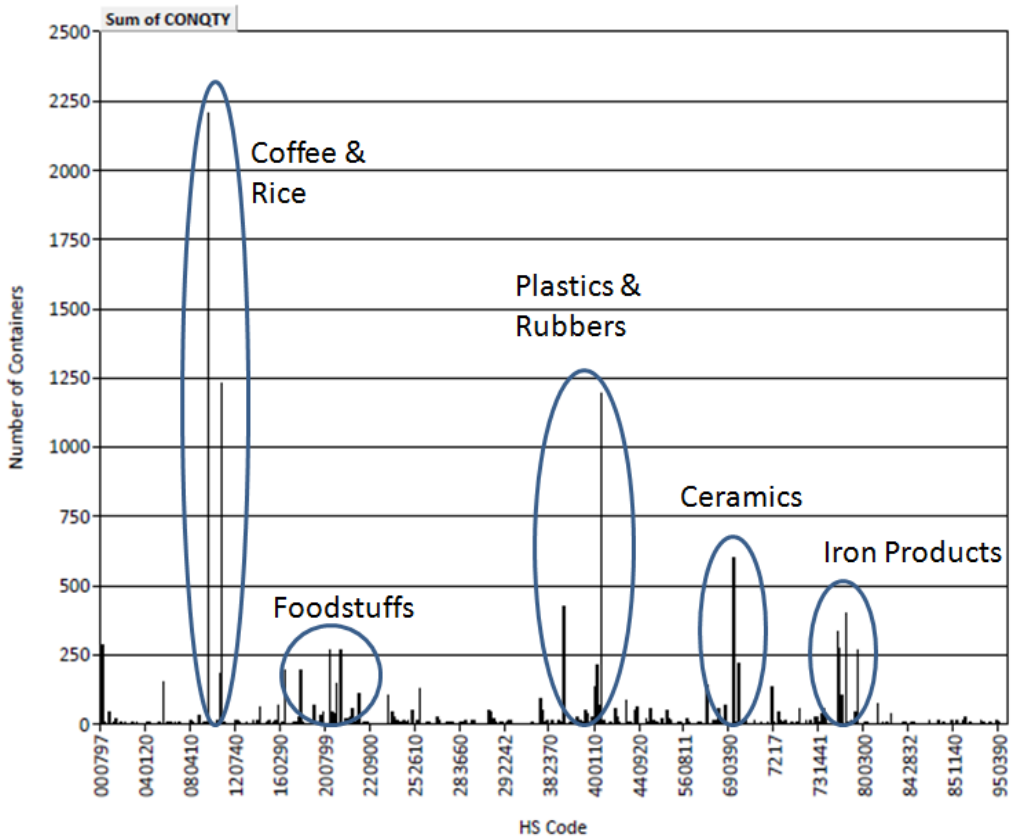

(c)

Figure 5: Commodity distributions for 20-ft containers from Singapore; (a) 0-15,000 lb/container, (b) 30,000-42,000 lb/container and (b) 42,000-50,000 lb/container, emphasizing several of the major commodities that contribute to the distribution in the specific weight range.

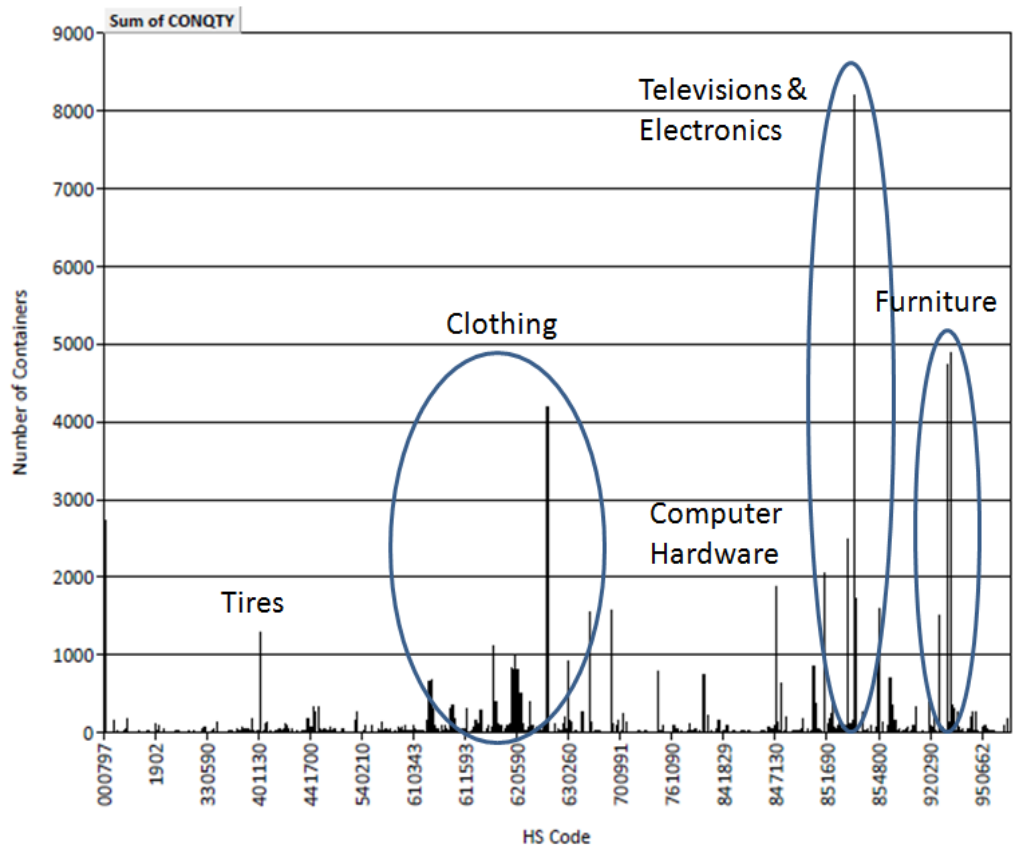

(a) 
PNNL-21088

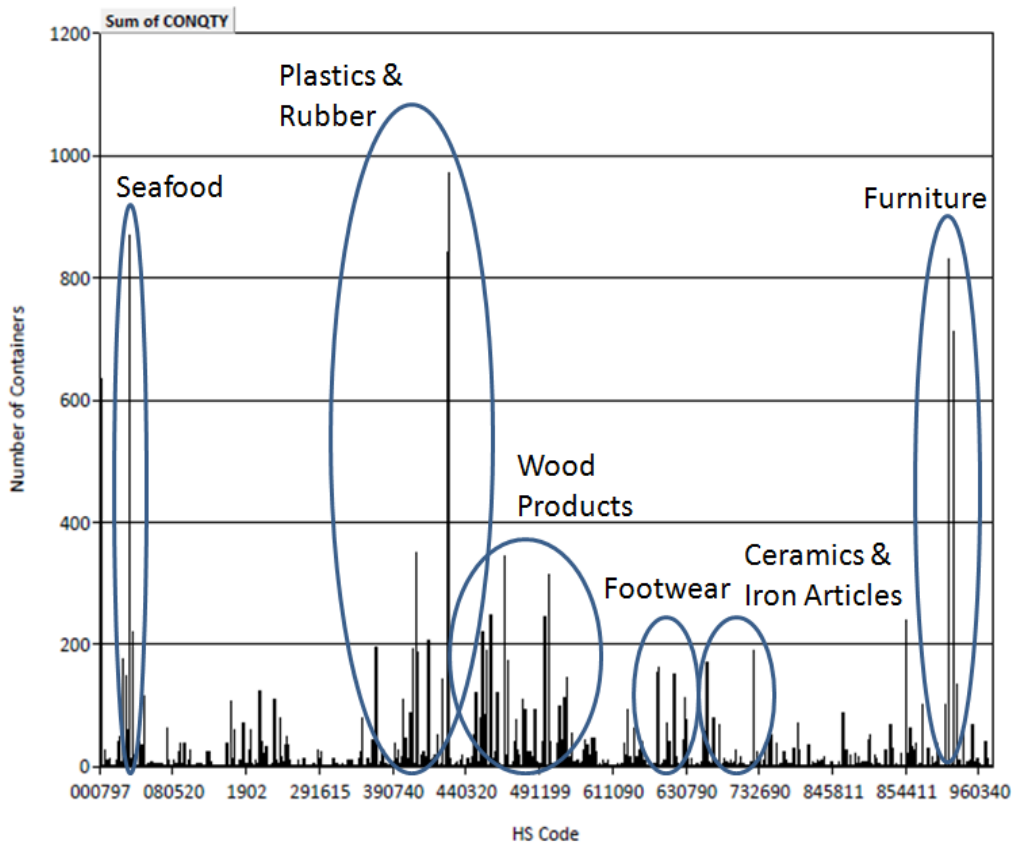

(b)

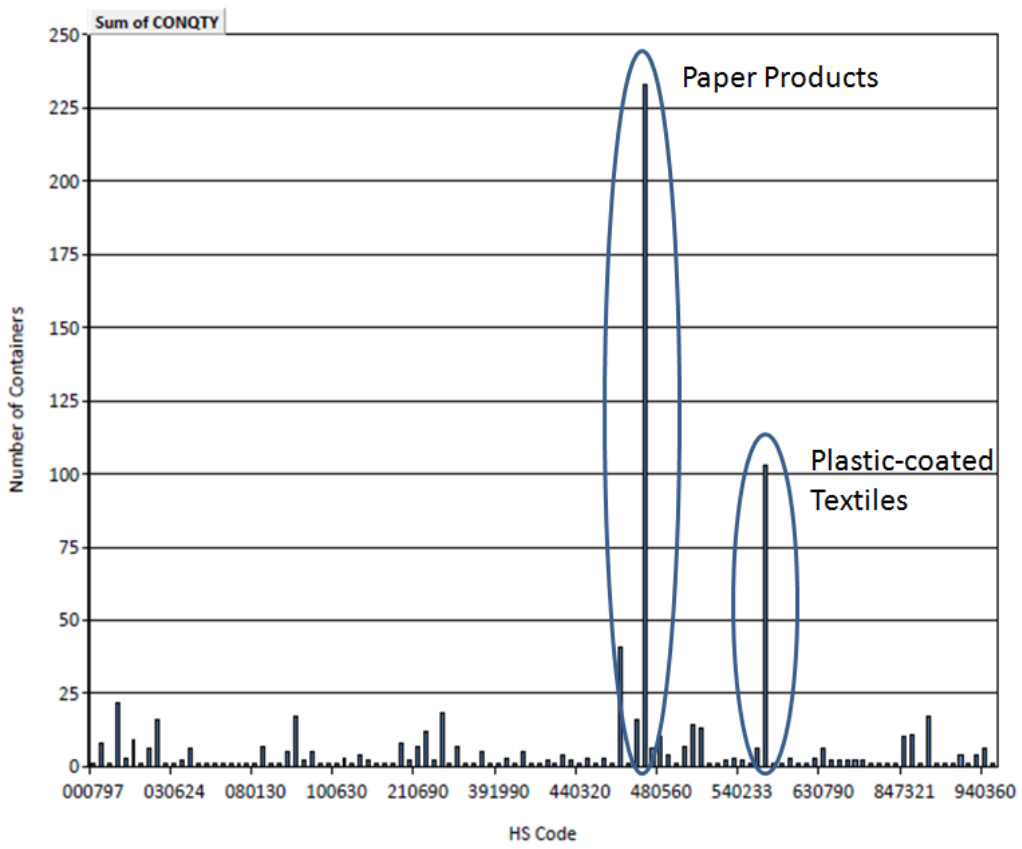

(c)

Figure 6: Commodity distributions for 40-ft containers from Singapore; (a) 0-30,000 lb/container, (b) 35,000-47,000 lb/container and (b) 50,000-60,000 lb/container, emphasizing several of the major commodities that contribute to the distribution in the specific weight range. 
As these figures demonstrate, the shipments from Singapore vary significantly from the global distribution, indicating that one cannot assume an "average" commodity distribution from a single foreign port. For 20 -ft containers from Singapore, the lower weight density is primarily dominated by clothing and footware, with some electronics and machinery. A significant number of this size of IMCCs contain plastic tableware. Further investigation in the database revealed that all of these containers were in a single entry, and the indicated commodity weight was 0 . Human error associated with the manifests/database can create significant errors in the analysis of commodities and shipments to the US, which can pose a significant challenge to isolate and correct. This particular entry was one example of the errors that can exist in these PIERS databases.

The higher weight distribution of 20-ft containers shows that plastics and rubber products and food products show some similarity to the global distribution, although there are some differences with specific commodities such as pumps, fans and batteries from Singapore within the 30,000-42,000 lb/container weight range. The highest 20 -ft container weight range also shows significant amounts of ceramic and iron products coming from Singapore.

Forty-foot containers from Singapore show a wide commodity variation depending on the chosen weight range. Containers less than 30,000 lb tend to ship clothing (low density), furniture (bulky), and televisions and electronics (packaged with significant packing material to reduce overall density). The broad peak distribution (35,000-47,000 lb/container) reveals a significant amount of seafood, furniture, plastic, and wood products shipped to the US. At higher weights (50,000-60,000 lbs), 40-ft IMCCs primarily contained paper products and plastic-coated textiles.

The 45-ft container distribution in Figure 7 shows that only a few specific commodities are shipped in this size of IMCC from Singapore. These include tires, a wide variety of clothing and footwear, medical equipment, and furniture. 
PNNL-21088

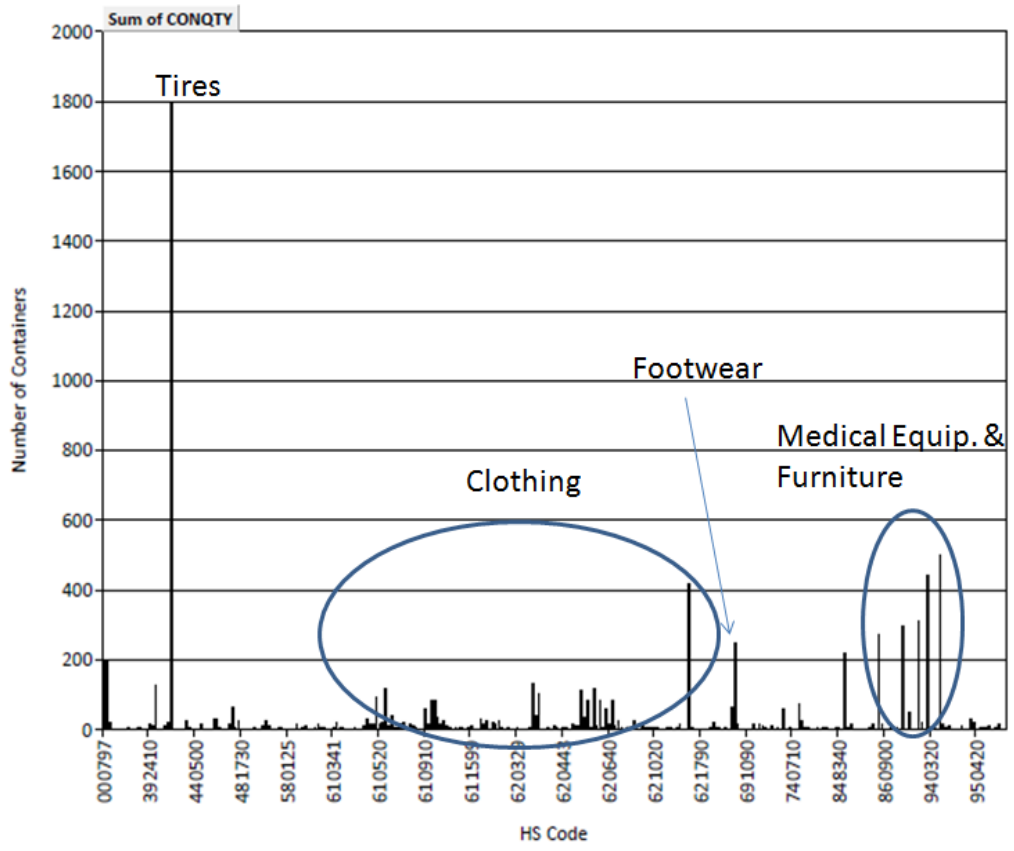

Figure 7: Commodity distribution for 45-ft containers from Singapore, with emphasis on several of the major commodities that contribute to the distribution

Table 9 shows a full summary of all containers shipped from Singapore based on major class categories defined by the HS code system (we separate the miscellaneous category into 2-digit HS codes for clarity). This table clearly distinguishes the major categories of commodities shipped from Singapore and compares them with shipments from all international ports. Singapore ships comparatively more vegetable products, plastics and rubber products, and clothing in 20-ft IMCCS than the rest of the international ports. Forty-foot containers shipped more clothing and electrical and machinery products (namely, televisions) from Singapore than an "average” international port. Plastics and rubber products, textiles, and medical equipment were more often shipped in 45-ft IMCCS from Singapore than from other international ports. While furniture still makes up a significant fraction of containers coming from Singapore, the respective fraction of each container size is reasonably close to the percentage from all international ports as indicated in Table 5. The breakdown for all 97 HS codes for IMCCs shipping from Singapore is shown in Appendix C of this report. 
Table 9: Shipping Container Data Arranged by Major HS Code

\begin{tabular}{|c|c|c|c|c|c|c|c|}
\hline \multicolumn{8}{|c|}{ Categories for Commodities from Singapore } \\
\hline $\begin{array}{c}\text { HS } \\
\text { Code } \\
\text { Range }\end{array}$ & Description & $\begin{array}{c}20-\mathrm{ft} \\
\text { Containers }\end{array}$ & Percent & $\begin{array}{c}40-\mathrm{ft} \\
\text { Containers }\end{array}$ & Percent & $\begin{array}{c}\text { 45-ft } \\
\text { Containers }\end{array}$ & Percent \\
\hline 00 & Household Goods & 1513 & 2.13 & 6981 & 4.77 & 475 & 5.22 \\
\hline 01-05 & Animal and Animal Products & 1114 & 1.57 & 7390 & 5.05 & 0 & 0.00 \\
\hline $06-15$ & Vegetable Products & 10,201 & 14.35 & 1642 & 1.12 & 26 & 0.29 \\
\hline $16-24$ & Foodstuffs & 6756 & 9.51 & 2740 & 1.87 & 3 & 0.03 \\
\hline $25-27$ & Mineral Products & 2279 & 3.21 & 67 & 0.05 & 0 & 0.00 \\
\hline $28-38$ & Chemical \& Allied Industries & 2833 & 3.99 & 1588 & 1.09 & 12 & 0.13 \\
\hline $39-40$ & Plastics \& Rubbers & 11,823 & 16.64 & 10,465 & 7.15 & 2014 & 22.12 \\
\hline $41-43$ & Raw Hides, Skins, Leather \& Furs & 384 & 0.54 & 693 & 0.47 & 30 & 0.33 \\
\hline $44-49$ & Wood \& Wood Products & 2557 & 3.60 & 8244 & 5.64 & 198 & 2.17 \\
\hline $50-63$ & Textiles \& Clothing & 7140 & 10.05 & 32,092 & 21.94 & 2740 & 30.09 \\
\hline $64-67$ & Footwear \& Headgear & 922 & 1.30 & 2564 & 1.75 & 338 & 3.71 \\
\hline 68-71 & Stone \& Glass & 5011 & 7.05 & 3709 & 2.54 & 58 & 0.64 \\
\hline $72-83$ & Metals & 7911 & 11.13 & 3822 & 2.61 & 187 & 2.05 \\
\hline $84-85$ & Machinery \& Electrical & 7599 & 10.69 & 35,195 & 24.06 & 855 & 9.39 \\
\hline $86-89$ & Transportation Products & 1388 & 1.95 & 2931 & 2.00 & 12 & 0.13 \\
\hline 90 & $\begin{array}{l}\text { Photograph and Medical } \\
\text { Instruments }\end{array}$ & 222 & 0.31 & 1672 & 1.14 & 460 & 5.05 \\
\hline 91 & Clocks \& Watches & 1 & 0.00 & 19 & 0.01 & 0 & 0.00 \\
\hline 92 & Musical Instruments & 79 & 0.11 & 944 & 0.65 & 56 & 0.62 \\
\hline 93 & Arms \& Ammunition & 0 & 0.00 & 1 & 0.00 & 0 & 0.00 \\
\hline 94 & Furniture & 808 & 1.14 & 20,893 & 14.28 & 1511 & 16.60 \\
\hline 95 & Toys, Games \& Sports Equipment & 320 & 0.45 & 1910 & 1.31 & 129 & 1.42 \\
\hline 96 & Manufactured Articles & 194 & 0.27 & 494 & 0.34 & 0 & 0.00 \\
\hline 97 & Works of Art \& Antiques & 16 & 0.02 & 208 & 0.14 & 1 & 0.01 \\
\hline
\end{tabular}




\subsection{Analysis of NORM Commodities Entering the United States}

NORM consists primarily of materials containing uranium, thorium, and potassium and their associated decay/daughter products. In the detection of nuclear contraband, NORM can create significant false alarm rates and cause delays in shipping from domestic ports. False alarms at shipping ports impact the US economy through shipping delays and spoilage of food products. In order to better understand the shipment of containers with NORM, we analyzed the 2006 PIERS database get an overview of shipment of NORM to the US, and analyzed specific NORM to learn how and from where these materials are shipped. It should be noted that we excluded a number of food products from our analysis (such as bananas and coffee) since their primary NORM is ${ }^{40} \mathrm{~K}$, which is easily screened by portal monitors and does not pose a significant false-alarm risk. Contained in this section is a breakdown of NORM materials that often contain sufficient levels of thorium, uranium, and their associated decay products, to create false alarms.

\subsection{Cat Litter}

For domestic portal systems, one of the largest contributors to radiological false alarms is cat litter; specifically, clay-based cat litter. Thus, it is important to inspect international shipping data to determine the extent to which cat litter may play a role in false alarms at ports of entry. The Harmonized System codes have no specific code for cat litter. The majority of cat litter used in the US is of the clumping variety, the main component of which is a specific type of clay material-bentonite-which has an identifiable HS code. A summary of all of the database entries for bentonite can be seen in Table 10 .

Table 10: Commodity Shipping Results for Bentonite (Common Mineral for Clumping Cat Litter)

\begin{tabular}{lllll}
\hline HS Code & Description & 20-ft Containers & 40-ft Containers & Other Containers \\
250810 & Bentonite & 6 & 20 & 0 \\
\hline
\end{tabular}

Thus, little to no cat litter that is shipped overseas to the United States should be a NORM false-alarm concern at international seaports (other HS codes were investigates as possible substitutes for cat litter). This makes sense as the US and Canada are major producers of cat litter (which may help explain why there is no specific HS code for cat litter). As a comparison, more than 4 million metric tons of cat litter is produced in the US every year, while the US consumes approximately 3 millions metric tons (according to the United State Geological Survey and an article by Mark Klaiman in Pet Product News (June 2008)). Other NORM and TENORM materials, however, are a far more significant concern in the overseas transport of goods to the US from international seaports, as detailed in the following subsections. 
PNNL-21088

\subsection{Fertilizers}

The amount of radioactive material in fertilizers is dependent upon the composition of the fertilizer, which is often specified in terms of percentage of nitrogen, phosphorus, and potassium. The phosphorous component of fertilizers is derived from phosphate rock. Since the latter, depending on its source, can be associated with uranium, and to a lesser extent, thorium deposits, the fertilizer's phosphorous content can impact detectors much like minute levels of the various members of the uranium series. The analysis in Radiation Exposure of the U.S. Population from Consumer Products and Miscellaneous Sources (National Council on Radiation Protection and Measurements 1987) indicates that the raw phosphate materials (such as ammonium phosphate, superphosphate, diammonium phosphate, and phosphoric acid) incorporated into fertilizer can contain a wide range of isotopic concentrations of several radionuclides, which are summarized in Table 11. Thus, it is important to understand how much fertilizer is shipped to the US, and from which ports we typically receive shipments containing fertilizer. In the production of fertilizers, the raw phosphate materials mentioned above are blended with low-phosphate materials. As a result of this blending, the concentrations of ${ }^{238} \mathrm{U},{ }^{230} \mathrm{Th},{ }^{266} \mathrm{Ra}$ and ${ }^{232} \mathrm{Th}$ in the final product are considerably lower (10 to 50\%) than the concentrations in Table 11 . The potassium component is usually derived from potash. Generally, the higher the level of potassium in the fertilizer, the higher the concentration of ${ }^{40} \mathrm{~K}$.

Table 11: Activity Concentrations of Radioisotopes Commonly Found in Phosphate Materials

\begin{tabular}{cc}
\hline Radioisotope & Activity Concentration (pCi/g) \\
\hline${ }^{238} \mathrm{U}$ & $22-140$ \\
${ }^{230} \mathrm{Th}$ & $5.4-430$ \\
${ }^{226} \mathrm{Ra}$ & $0.7-24$ \\
${ }^{232} \mathrm{Th}$ & $0.14-4.6$ \\
\hline
\end{tabular}

To analyze the shipment of fertilizers, we collected information pertaining to HS code 31 (2-digit HS code for fertilizers), and all associated 4- and 6-digit codes. The number of containers shipped in 2006 was 5763, almost equally split between 20 - and 40 -ft containers. The distribution for international ports from which fertilizers were shipped to the US in 2006 is shown in Figure 8. The database indicated that the largest shipments of fertilizers come from Israel, which compares well with a previous study (Descalle et al. 2006). In addition, a large number of European ports also shipped these materials to the US, as well as several Caribbean ports. A small number of Asian ports shipped fertilizer, although Yokohama (Japan) shipped the largest number of 20 -ft containers with fertilizer. 


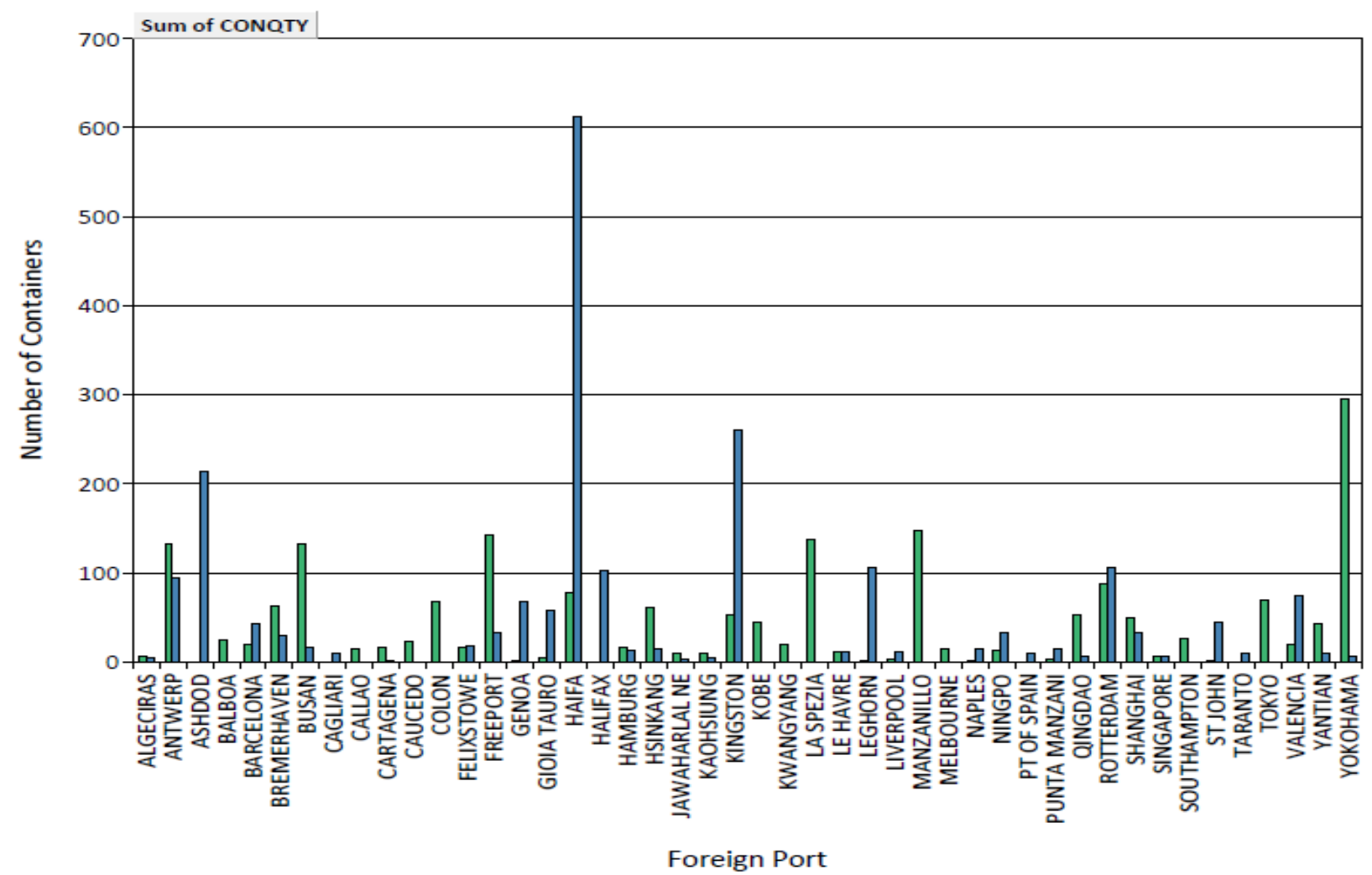

Figure 8: Foreign ports that ship fertilizer to the US. This includes fertilizers of all compositions, including pure nitrogen-based fertilizers, which do not present a NORM challenge. This distribution also included mixed nitrogen, phosphorous, and potassium fertilizers. Note: Only ports that ship more than nine containers per year are included in the above distribution.

\subsection{Ceramics}

Ordinary ceramics often contain elevated levels of naturally-occurring radionuclides such as ${ }^{40} \mathrm{~K}$ and the various members of the uranium and thorium decay series. Sometimes the higher readings are due to uranium in the glaze; other times they are due to elevated concentrations of naturally-occurring radioisotopes in the clays used to produce the ceramic and porcelain material. Ceramics can be particularly radioactive if some compound of uranium (e.g., uranium oxide, sodium uranate) has been used to impart color (e.g., orange-red, green, yellow, black) to the glaze. It is widely known that uranium was used in the glaze of orange-red Fiesta dinnerware, but uranium glazes have also been used in other types of ceramics such as wall and floor tiles, pottery, laboratory ceramics, etc. The glazes are useful not only to provide color, but also to seal the ceramic.

To analyze the shipment of ceramic materials, we collected information pertaining to HS code 69 (ceramics), and all associated 4- and 6-digit codes. The number of containers shipped in 2006 was over 225,000 and is one of the largest quantities of all commodities shipped to the US (as can be seen in Appendix B). Ceramic materials happened to account for the second largest quantity of 20-ft containers shipped to the US. Approximately $62 \%$ of containers filled with ceramics are $20 \mathrm{ft}$ long, $38 \%$ are $40 \mathrm{ft}$ 
long, and the remainder are $45 \mathrm{ft}$ long or another length. The weight distribution of containers with ceramic materials that were shipped to the US in 2006 is shown in Figure 9.

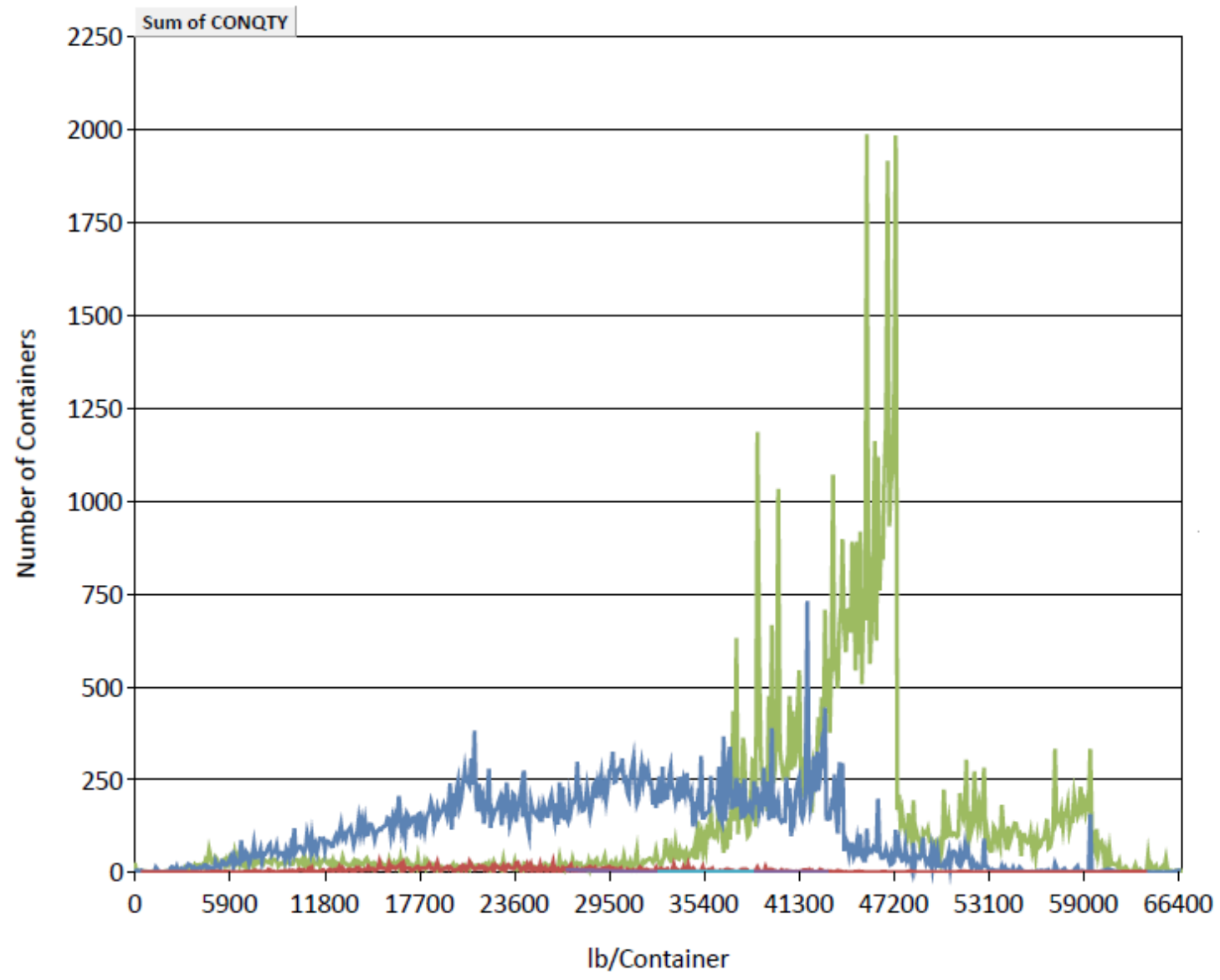

Figure 9: Global container weight distribution for all ceramic products

The weight distribution has some unique features. For example, the $40-\mathrm{ft}$ container weight distribution slowly rises from about 5000 to $20,000 \mathrm{lb}$, and is relatively flat up to about 44,000 lb. Very few 20-ft containers weighing less than 35,000 lb were shipped in 2006, and the distribution rises sharply until approximately 47,000 lb/container, at which point the number of containers with a higher mass falls dramatically to about 100 , and stays relatively flat until 60,000 lb/container. Such unique weight distributions for the different sizes of containers invited further analysis, yielding interesting results concerning the distribution of container sizes.

We performed a separate analysis to determine the foreign ports from which the three container sizes were shipped (including the approximately 320045 -ft containers that shipped ceramic products). Figures 10,11 , and 12 show the foreign port distribution for ceramic materials shipped to the US in 20-, 40-, and 45-ft containers, respectively. The figures show that different sizes of containers came from different international ports. For example, a majority of 20 -ft containers came from Europe and South America. 40-ft containers almost exclusively came from Asian ports, mostly Chinese or Korean ports. Forty-five- 
foot containers originated mostly in China, with Yantian shipping over $40 \%$ of all containers of this size. This compares well with Table 1, where the port of Yantian shipped nearly 30\% of all $45-\mathrm{ft}$ containers coming to the US in 2006.

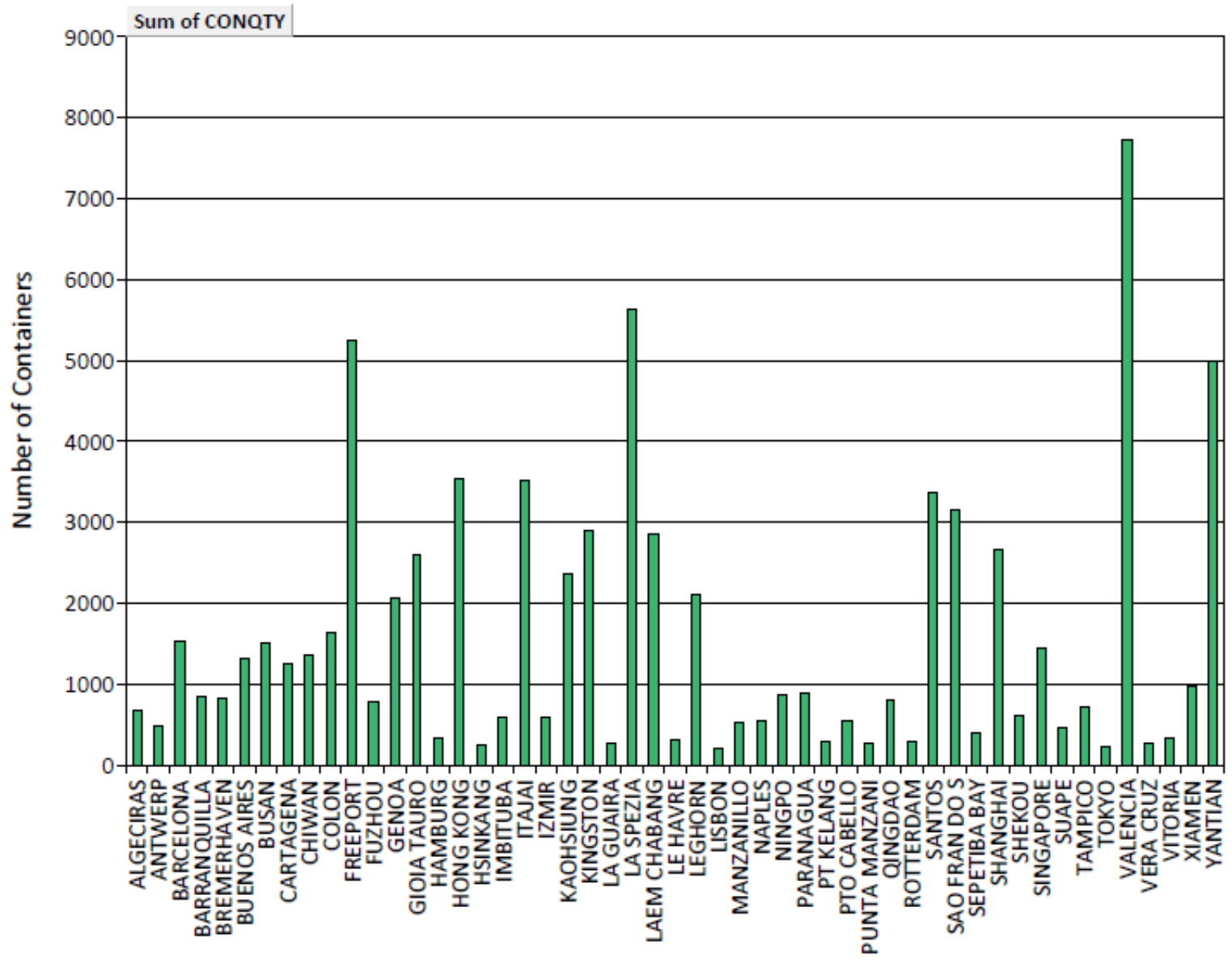

Foreign Port

Figure 10: Foreign ports that ship ceramic products to the US in 20-ft containers. Note: Only ports with shipments in excess of 100 containers are shown.

We then expanded the analysis of ceramic shipments to the US to determine how different ceramic commodities were shipped to the US. Appendix D shows the consolidated container data for ceramic materials shipped to the US, expanded by the 4- and 6-digit HS code. The table shows that for HS codes less than 6909, the commodity tends to be shipped in 20-ft containers, while higher HS code numbers are shipped in 40-ft containers. Examination of the code descriptions revealed that the lower-valued HS codes are designated for ceramic items such as floor tiles, roof tiles, bricks and other refractory ceramic goods ("construction ceramics"). Higher-numbered HS codes are designated for ceramic items such as tableware, sinks, tubs, and the like, or "consumer ceramics.” Thus, it can be deduced that much of the consumer ceramic products was imported from Asian ports (mostly China) and that imported construction 
ceramics had a more world-wide distribution, with many containers coming from Europe, Central and South America, as well as Asia.

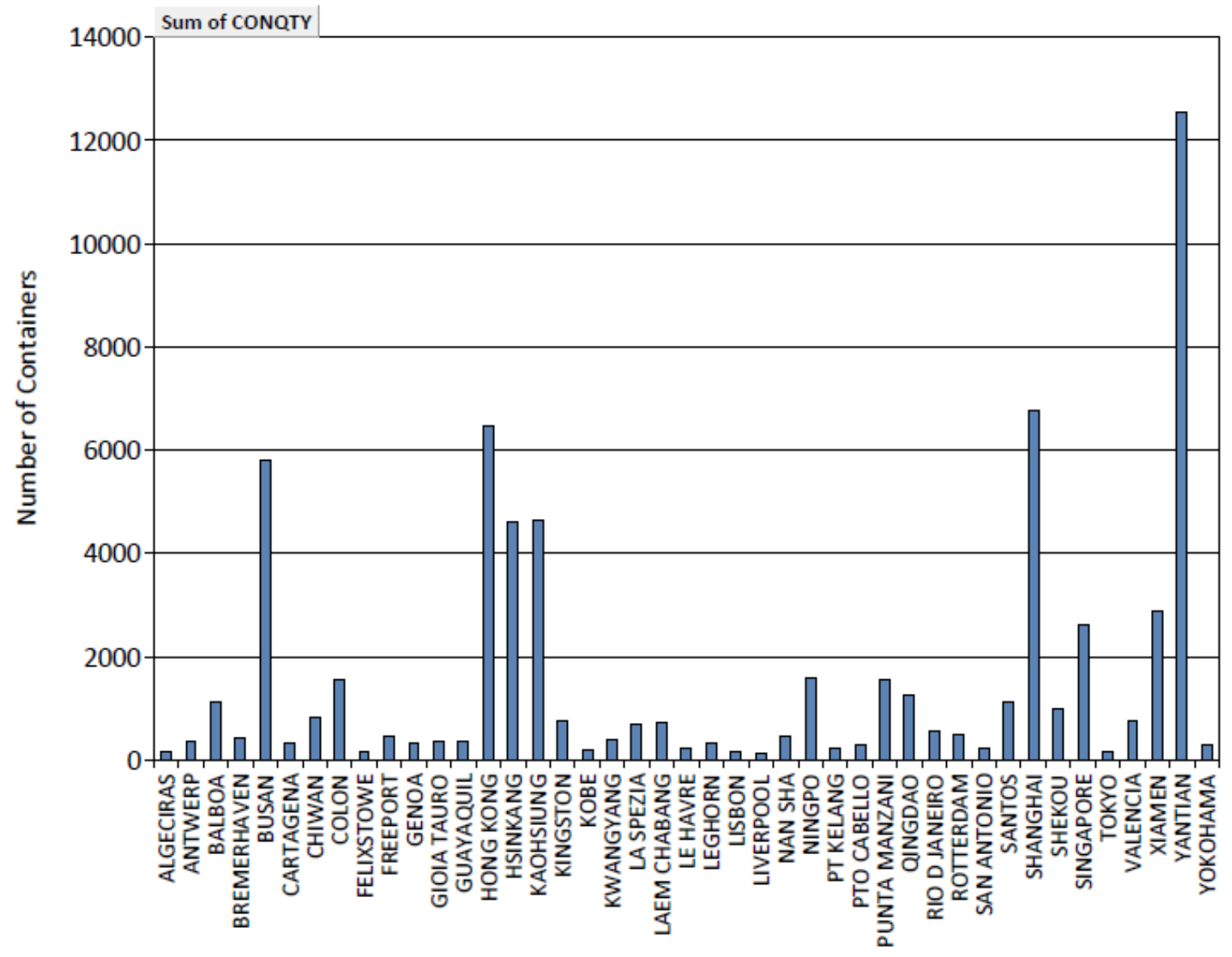

Foreign Port

Figure 11: Foreign ports that ship ceramic products to the US in 40-ft containers. Note: Only ports shipping more than 100 containers are shown.

Figure 13 provides the weight distributions for construction and consumer ceramic goods, which shows that construction ceramics were responsible for the peak in the distribution for 20 - $\mathrm{ft}$ containers from 35,000-47,000 lb/container, along with the higher weights for both 20 - and 40-ft containers. Consumer ceramics showed a flat weight distribution not only for 40-ft containers, but also for 20 - and 45 -ft containers. The sharp decrease for 40 - $\mathrm{ft}$ containers that shipped consumer ceramics may be due to the fact that many of these products are packed in Styrofoam ${ }^{\mathrm{TM}}$-filled boxes and this could be the maximum volume of these boxes that can be shipped in the 40-ft container. Construction ceramics are often shipped without foam packaging, in less dense cardboard, such that more of the actual product can be shipped in a single container, and these materials reach the container's maximum shipping weight prior to reaching its volumetric limit. 
PNNL-21088

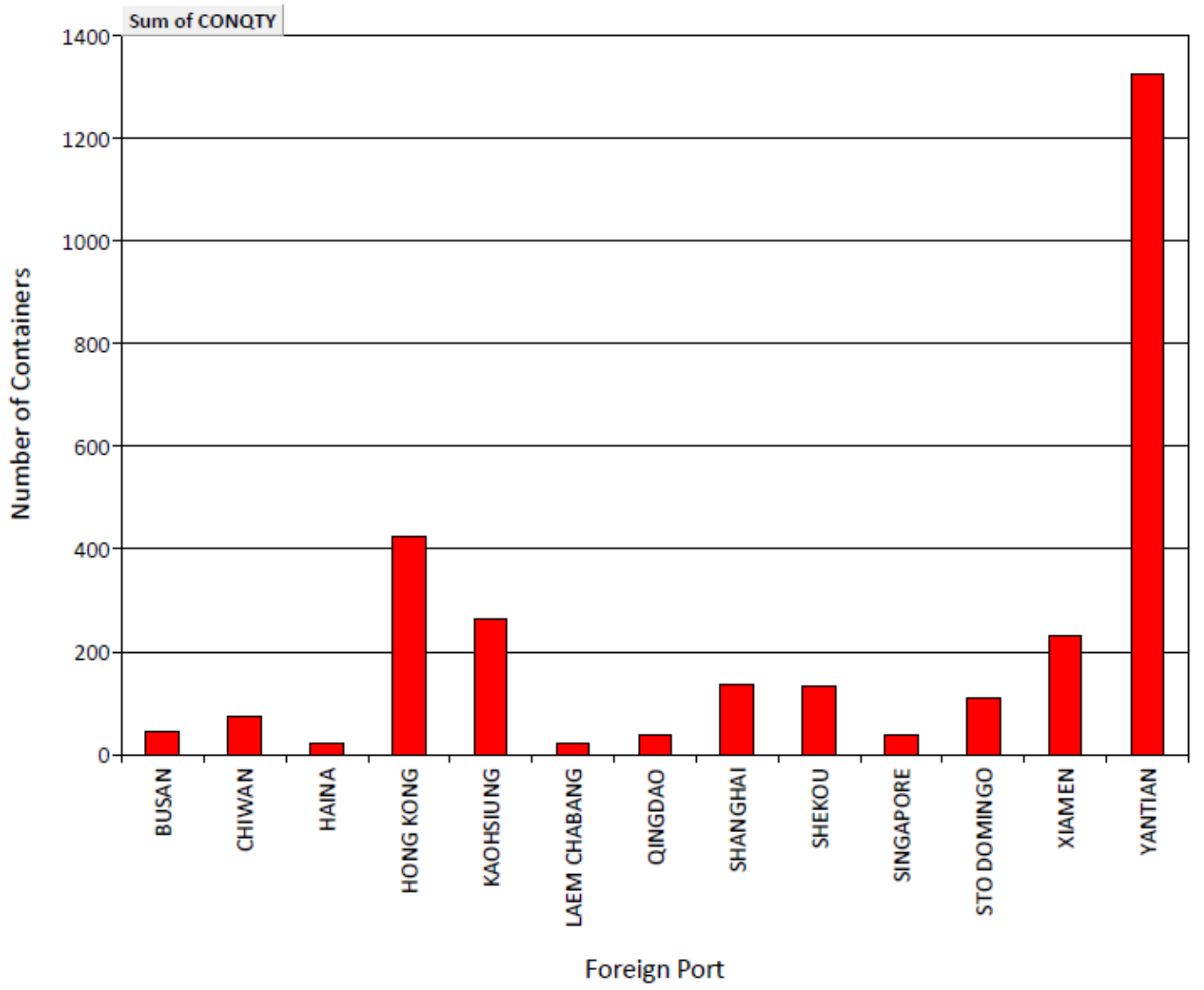

Figure 12: Foreign ports that ship ceramic products to the US in 45-ft containers. Note: Only ports with shipments in excess of 20 containers are shown. 
PNNL-21088

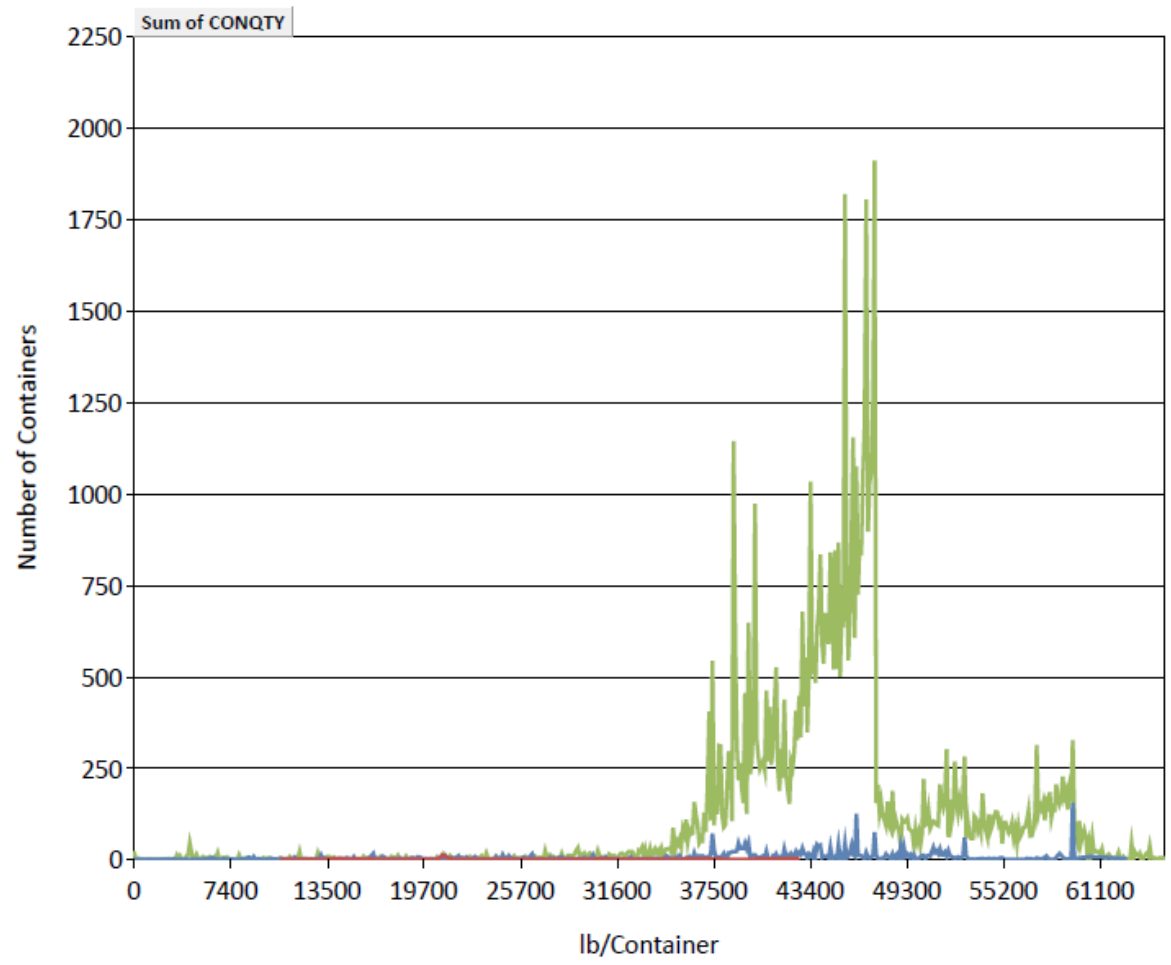

(a)

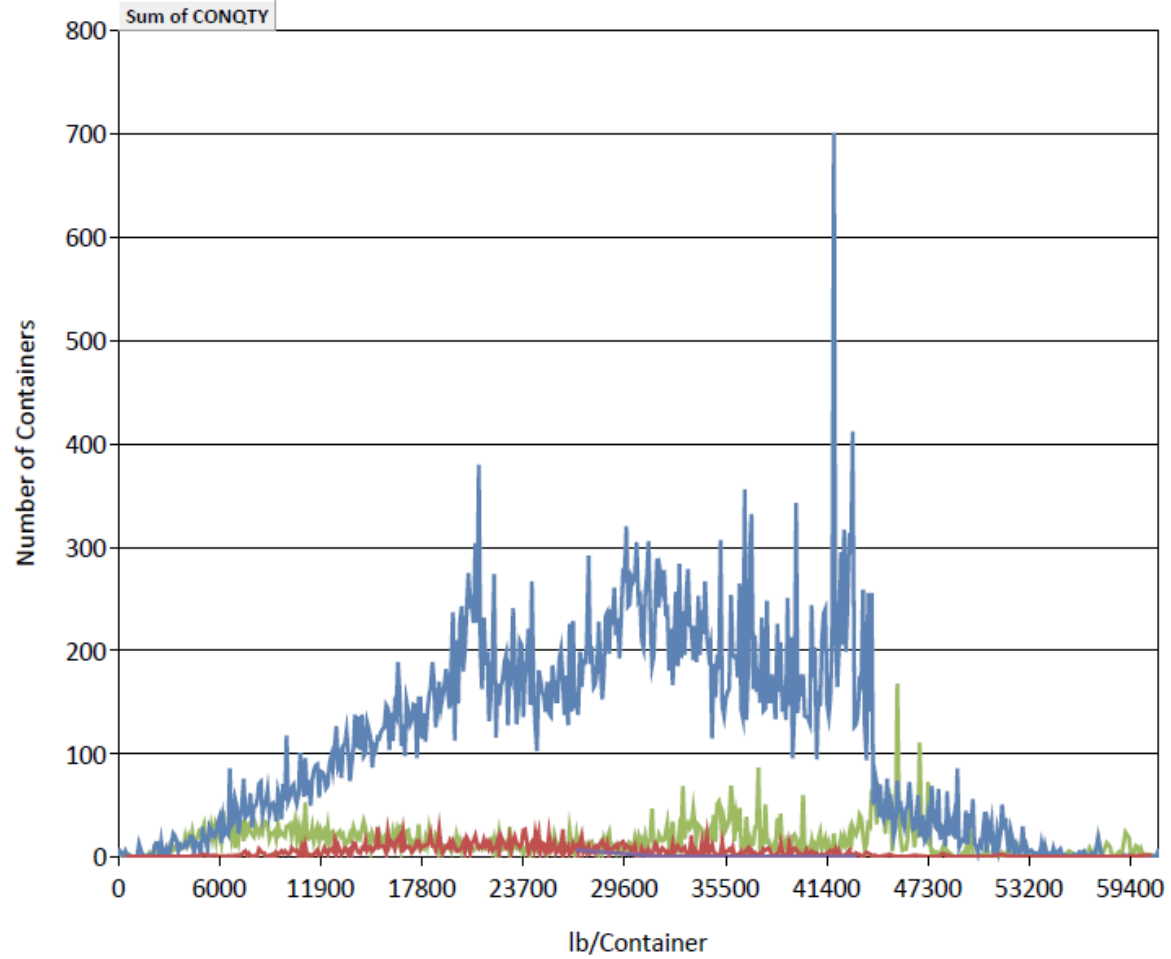

(b)

Figure 13: Container weight distribution for (a) "construction" ceramic goods, and (b) "consumer" ceramic goods 


\subsection{Granite}

Any naturally formed rock material has the potential to contain varying amounts of naturally occurring radiation. Natural radioactive elements like uranium, radium, and thorium can be present in a wide number of minerals that appear as crystals in granite from around the world. It is not unusual for materials such as granite to have some amount of radioactivity. Depending on the composition of the molten rock from which they formed, some pieces of granite can exhibit more radioactivity than others. Table 12 supplies typical activity concentration ranges for isotopes commonly found in granite (National Council on Radiation Protection and Measurements 1987), although values can greatly deviate from this range depending on the specific type of granite and specific locations within a slab of granite.

Table 12: Activity Concentrations of Radioisotopes Commonly Found in Granite

\begin{tabular}{cc}
\hline Radioisotope & Activity Concentration (pCi/g) \\
\hline U-238 & $0.34-3.4$ \\
Th-230 \& Th-232 & $0.54-3.2$ \\
K-40 & $\sim 2.7$ \\
\hline
\end{tabular}

To analyze the shipment of ceramic materials, we collected information pertaining to four HS codes that are referenced for granite shipments: 251611, 251612, 680223, and 680293. The number of containers shipped in 2006 was 59,427. Approximately $96 \%$ of containers filled with granite were 20 -feet long, $4 \%$ were 40 -feet long, and just 20 containers were 45-feet long. The weight distribution of granite-filled containers that were shipped to the US in 2006 is shown in Figure 14. The majority of containers are in the $37,000-47,000-\mathrm{lb}$ range, with a tail up to approximately $63,000 \mathrm{lb}$ for 20 -ft containers. The large oscillations in the weight distribution are due to how the original database is assembled. A single record in the database can contain information for more than one container (the 2006 database used in this report had up to 2000 containers in a single record). The weight information was then averaged over the number of containers in the record, and rounded to the nearest $100 \mathrm{lb}$. The combination of averaging over the record and rounding led to the large number of spikes in the data. The best method to smooth out these oscillations would be to use a larger bin structure for weight (i.e., instead of rounding to the nearest $100 \mathrm{lb} /$ container, round to the nearest $500 \mathrm{lb} /$ container).

We also investigated the foreign port distribution for granite-filled containers. The results are shown in Figure 15 and Figure 16 for 20- and 40-ft containers, respectively. Twenty-foot containers, the primary container used in shipping granite, were shipped from a larger variety of foreign ports, across all global regions. The port of Freeport (Bahamas) appears to ship the largest number of 20-ft (and as a group, 20and 40-ft) containers to the US. This can be misleading as Freeport is not necessarily the originating port. Freeport is in a free-trade zone (operated by the Grand Bahama Port Authority), and this port actually handles containers from other international ports that are ultimately destined for the eastern seaboard of the US. Other countries that ship a large number of 20-ft granite-filled containers include Brazil, and China. This makes sense as Brazil and East Asia are major origination points of granite slabs that are imported to the US for home/building construction purposes. It is interesting to note that 40 -ft containers 
PNNL-21088

are primarily shipped by Chinese ports and Busan (South Korea), and that the weight carried by these containers is within the same range as 20 -ft containers.

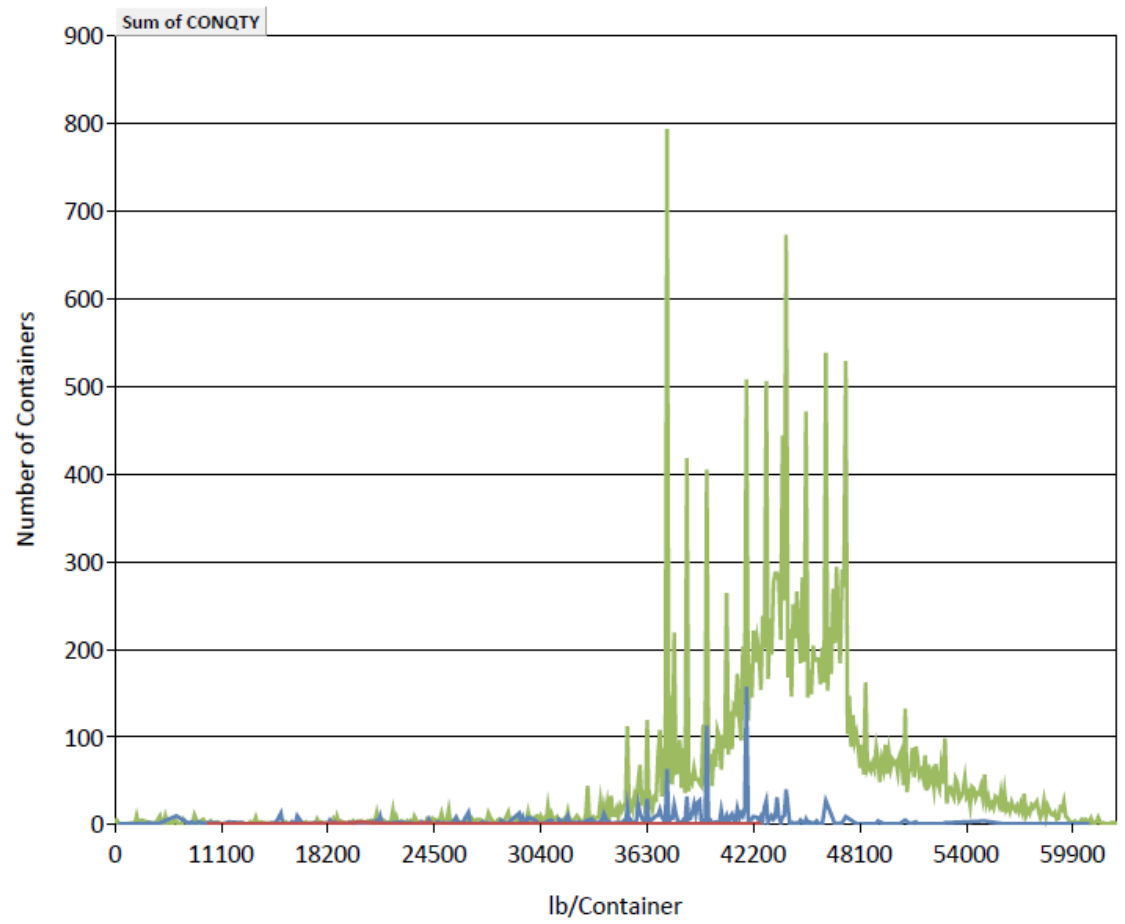

Figure 14: Container weight distribution for granite materials 
PNNL-21088

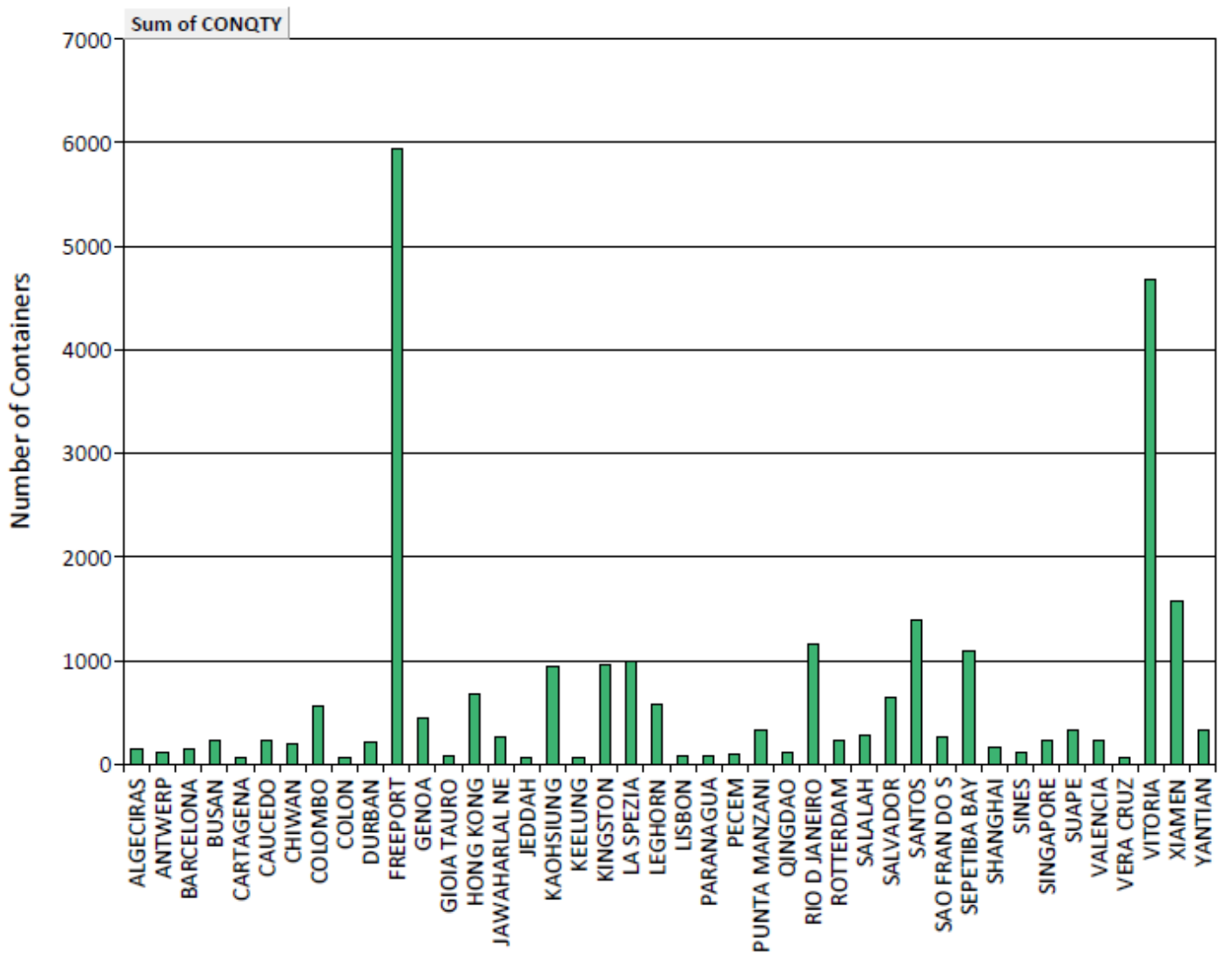

Foreign Port

Figure 15: Foreign port distribution of granite materials shipped in 20-ft containers. Only ports that shipped more than 50 containers in 2006 are shown. 


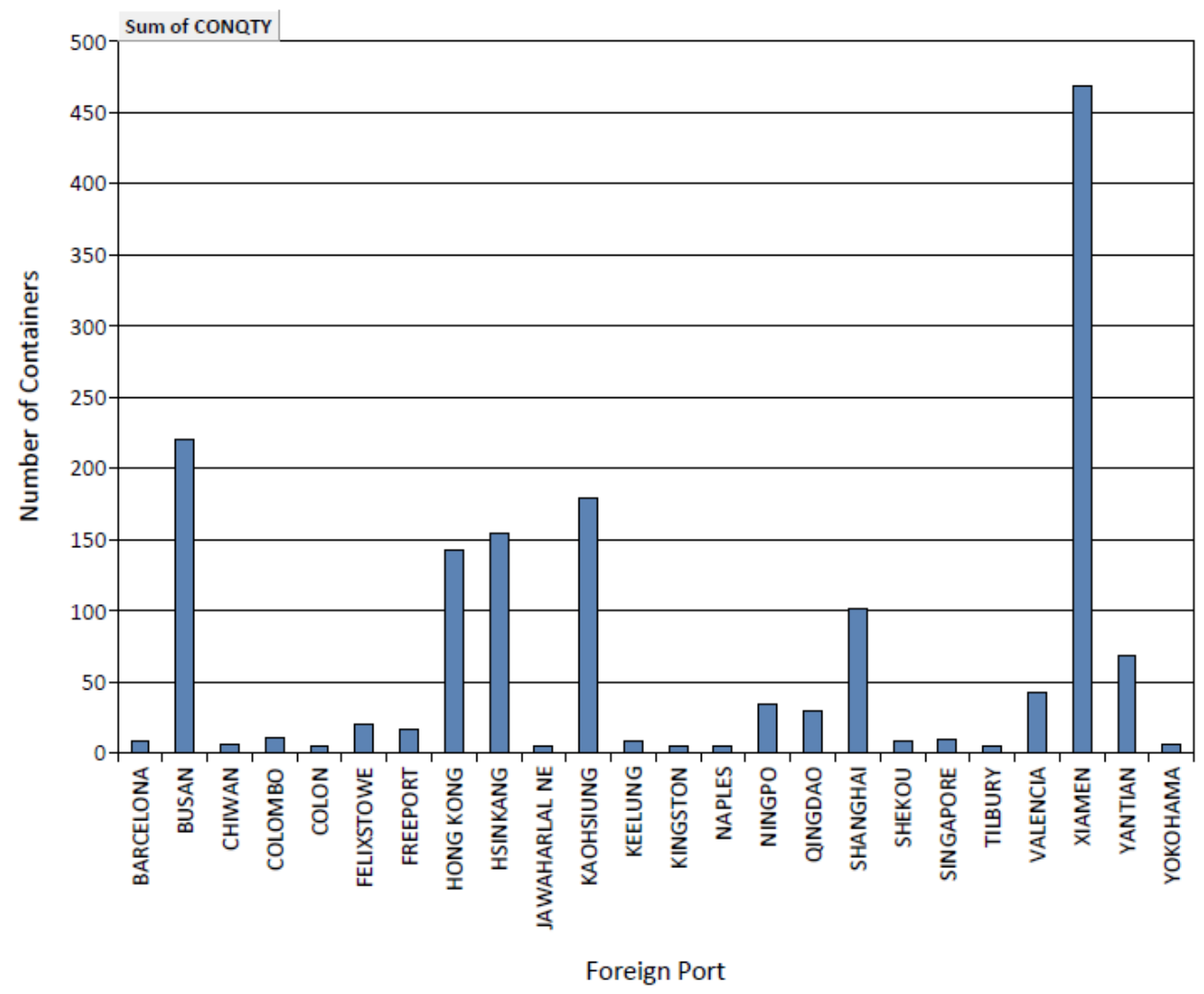

Figure 16: Foreign port distribution of granite materials shipped in 40-ft containers. Only ports that shipped upwards of five containers in 2006 are shown.

\subsection{Radiological Materials}

It is important to recognize the places from which the US may receive overseas shipments of radiological materials (HS Code 2844), even though these may not be naturally-occurring nor represent a false-alarm challenge as NORM can. These materials consist of natural, enriched, and depleted uranium, plutonium, thorium, and other radioisotopes. Residues, alloys, and mixtures are included in this category. In addition, highly radioactive spent-fuel elements of nuclear reactors are also included as part of this 4-digit HS code. In 2006, 565 containers of such materials were shipped.

Approximately $70 \%$ of these containers filled with radioactive materials were 20 -feet long, $30 \%$ were 40 feet long, and just 3 containers were 45-feet long. Seventy-six percentof the containers were labeled with HS Code 284440, which presents radioisotopes other than uranium, plutonium, or thorium. The average weight in these shipping containers was approximately 30,000 lb, and it is assumed that a significant fraction of this weight can be attributed to shielding for radiation protection. As Figure 17 reveals, a majority of the containers come through European (and Russia's Asian) ports, with Antwerp, Liverpool and St. Petersburg being the largest shippers of radioactive materials to the US. 
PNNL-21088

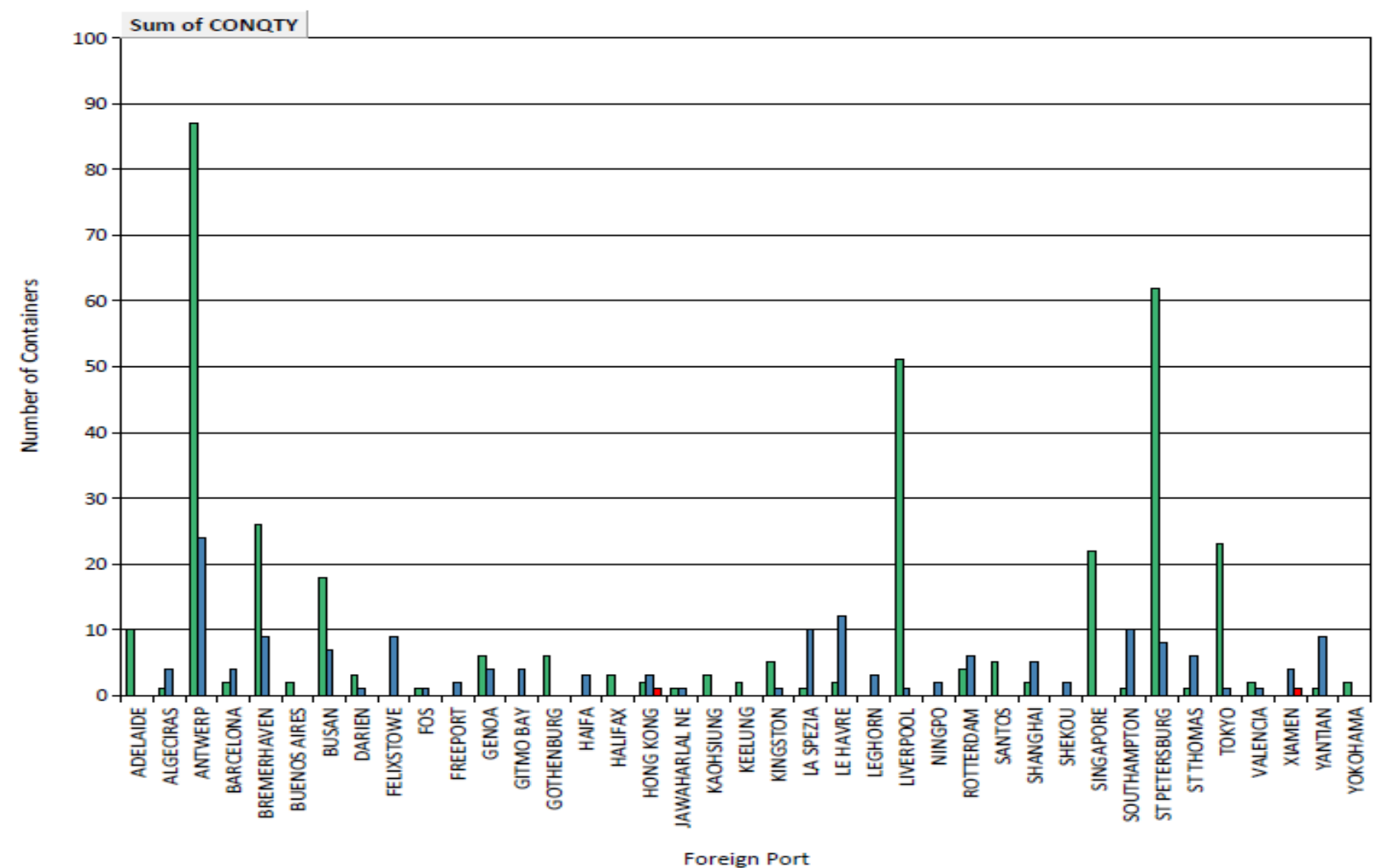

Figure 17: Foreign port distribution for containers with radiological materials (including spent fuel)

\subsubsection{Uranium Ore}

Another commodity of particular interest is uranium ore, which has its own separate HS code (261210). In 2006, 161 20-ft containers were shipped to the US, with an average weight of 47,900 lb/container. Figure 18 illustrates that most of these containers came from Singapore, with an additional 19 containers originating from Australian ports. It should be noted that only two US ports received uranium ore in 2006: Philadelphia and New Orleans. Further, only seven cargo ship voyages carried the containers. 
PNNL-21088

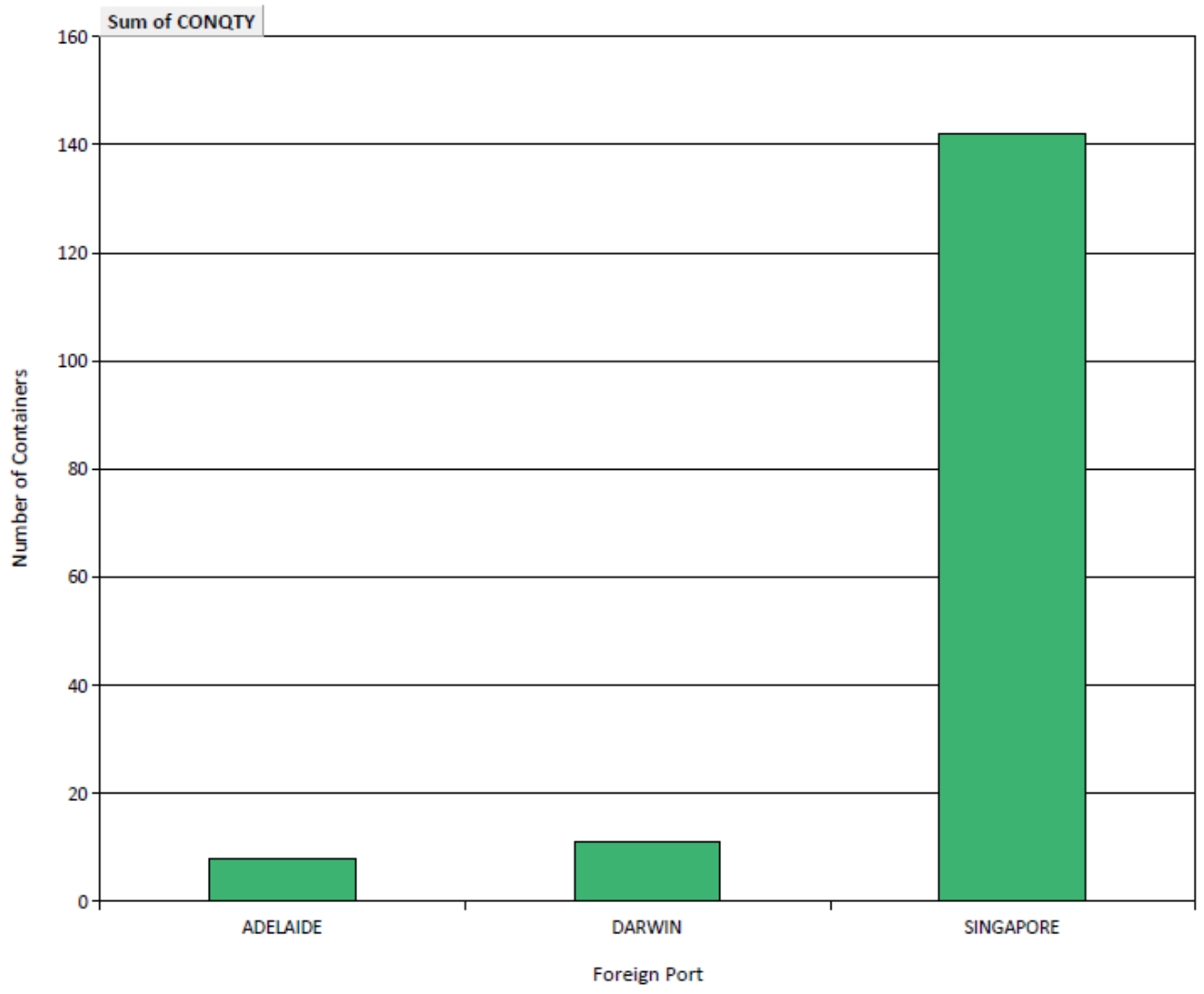

Figure 18: Foreign port distribution of containers with uranium ore 
PNNL-21088

\subsection{Summary and Conclusions}

Each container size has a unique weight distribution for all commodities. In general, bulkier commodities such as furniture, clothing, fruits and vegetables are shipped in 40 -ft containers, while dense items such as rock products, bulk metals, and beverages are shipped in 20 - $\mathrm{ft}$ containers. The majority of containers shipped to the United States are $40-\mathrm{ft}$ containers ( 70\%), about $25 \%$ are $20-\mathrm{ft}$, and about $4 \%$ are $45-\mathrm{ft}$ containers. A small fraction $(<1 \%)$ of containers are of other, specialized sizes, and very few ports actually ship these uniquely-sized containers. Given that 45-ft containers comprise 1 of out every 27 containers shipped to the US, and bearing in mind the foreign ports from which they are shipped, they should not be ignored in screening. Further testing and analysis of radiation measurements for national security with this size container is warranted.

A great deal of information can be obtained from the PIERS database, in particular enabling the analysis of shipping through specific international ports. Analyzing this data affords us an excellent tool for understanding shipping and developing a better understanding of the risks associated with potential cargoborne nuclear and radiological threats within the Second Line of Defense (SLD) and Radiation Portal Monitor Project (RPMP) framework. This report analyzed Singapore as an example port. Of all the international ports, Singapore shipped the sixth-largest volume of containers to the US in 2006. In general, Singapore shipped more vegetable products, clothing, electronics (mostly in the form of televisions and computer parts), plastic and rubber products than a typical foreign port. In 2006, Singapore was also the main port through which uranium ore was shipped to the US. Additionally, Singapore shipped less than the average amount of stone and glass materials, base metals, and toys. Singapore also shipped a slightly larger percentage (approximately 4\%) than average of 45 -ft containers.

While a large number of NORMs are shipped in IMCCs, only a few specific commodities are shipped with enough frequency to present potential issues in screening IMCCs at ports. The majority of containers with NORM will hold fertilizers, granite, or ceramic materials (either general ceramic or porcelain). Fertilizers were generally shipping in either 20 - or $40-\mathrm{ft}$ containers with equal frequency. While granite is mostly shipped in 20-ft containers, ceramic materials can be shipped in either 20- or 40-ft containers. The size of container depended on the specific use of the ceramic or porcelain material. General construction ceramics (such as floor and roof tiles) tend to be shipped in 20-ft containers. Consumer products made from ceramic materials (e.g., tableware, sinks, and toilets) are generally shipped in 40 -ft containers. This notable divergence is due in large part to the differential packaging of the ceramic commodities. Consumer products are usually shipped packed with significant quantities of Styrofoam ${ }^{\mathrm{TM}}$ or other packing material to protect the product from breakage, reducing its overall density, whereas construction ceramic materials are commonly shipped with much less protective material, many times consisting of only a cardboard or wood box, changing its effective density very little. Granite is almost always shipped in a 20 -ft container, owing to its very high density. Uranium ore, sent exclusively in 20 -ft containers, is primarily shipped from Singapore. Other radioactive materials are mostly shipped in $20-\mathrm{ft}$ containers and originate from European ports.

In future studies with the PIERS databases, analysis would be improved by the use of more of the entry fields than the set available for this report. Unfortunately, the omission of several key fields in the dataset prevented the proper analysis of commodities that were listed with "unknown" or "less than container" sizes (representing commodities that used a partial container with multiple commodities). Had there been a greater number of data entries, it might have been possible to infer the container sizes for these 
commodities. The data analyzed and conclusions drawn in this report are based on shipping information from 2006 (and only for the database entries in which the container size was known, accounting for 70\% of the total amount of commodities shipped to the US). In view of the dynamic changes that can occur within international shipping, there is value in performing a similar analysis with a more recent database, in order to better assess year-to-year and port-to-port variations in support of SLD and RPMP objectives. By analyzing multiple years worth of commodity information, improved results and conclusions about shipments from overseas ports can be drawn. 
PNNL-21088

\subsection{References}

Descalle, MA, D Manatt, and D Slaugther. 2006. Analysis of Recent Manifests for Goods Imported through US Ports. Report No. UCRL-TR-225708, Lawrence Livermore National Laboratory, Livermore, CA.

Foreign Trade On-Line Corporation. 1999. Foreign Trade On-line. Accessed on September 8, 2011 at http://www.foreign-trade.com/ (last updated 2011).

National Council on Radiation Protection and Measurements. 1987. Radiation Exposure of the U.S.

Population from Consumer Products and Miscellaneous Sources. Report No. 95, NCRP, Bethesda, MD.

Schumacher Cargo Logistics. 2011. Cargo Shipping Container Sizes. Accessed on October 21, 2011 at http://www.schumachercargo.com/shipping-container-sizes.html (last updated 2011). 
PNNL-21088

\section{Appendix A: List of All International Ports and Number of Containers Shipped to the United States}

This appendix lists the international shipping ports and the number of containers shipped from each to the

US in 2006. Containers sized 20, 40, and $45 \mathrm{ft}$ are listed separately. Other containers sizes (e.g., $48 \mathrm{ft}$, $53 \mathrm{ft}$, etc.) are listed in a combined Other category. 
PNNL-21088

\begin{tabular}{|c|c|c|c|c|c|c|c|c|}
\hline Foreign Port & $\begin{array}{c}20-\mathrm{ft} \\
\text { Containers }\end{array}$ & $\begin{array}{l}\text { Percent } \\
\text { of Total }\end{array}$ & $\begin{array}{c}40-\mathrm{ft} \\
\text { Containers }\end{array}$ & $\begin{array}{l}\text { Percent } \\
\text { of Total }\end{array}$ & $\begin{array}{c}45-\mathrm{ft} \\
\text { Containers }\end{array}$ & $\begin{array}{l}\text { Percent } \\
\text { of Total }\end{array}$ & Other & $\begin{array}{l}\text { Percent } \\
\text { of Total }\end{array}$ \\
\hline AABENRAA & 9 & 0.0005 & 88 & 0.0017 & & 0.0000 & & 0.000 \\
\hline AALESUND & & 0.0000 & 10 & 0.0002 & 2 & 0.0008 & & 0.000 \\
\hline AARHUS & 37 & 0.0020 & 15 & 0.0003 & & 0.0000 & & 0.000 \\
\hline ABIDJAN & 1104 & 0.0595 & 242 & 0.0047 & & 0.0000 & & 0.000 \\
\hline ACAJUTLA & 905 & 0.0488 & 2959 & 0.0579 & 446 & 0.1703 & & 0.000 \\
\hline ADELAIDE & 253 & 0.0136 & 38 & 0.0007 & & 0.0000 & & 0.000 \\
\hline AGANA & 605 & 0.0326 & 1241 & 0.0243 & 285 & 0.1088 & & 0.000 \\
\hline ALEXANDRIA & 661 & 0.0356 & 2135 & 0.0418 & 4 & 0.0015 & 1 & 0.006 \\
\hline ALGECIRAS & 18,750 & 1.0108 & 22,051 & 0.4317 & 92 & 0.0351 & & 0.000 \\
\hline ALGIERS & & 0.0000 & 1 & 0.0000 & & 0.0000 & & 0.000 \\
\hline ALICANTE & 31 & 0.0017 & 2 & 0.0000 & & 0.0000 & & 0.000 \\
\hline ALTAMIRA & 1 & 0.0001 & & 0.0000 & & 0.0000 & & 0.000 \\
\hline AMSTERDAM & 115 & 0.0062 & 204 & 0.0040 & & 0.0000 & & 0.000 \\
\hline ANCONA & 9 & 0.0005 & 44 & 0.0009 & & 0.0000 & & 0.000 \\
\hline ANDROS ISL & 55 & 0.0030 & 1 & 0.0000 & & 0.0000 & & 0.000 \\
\hline ANTALYA & 3 & 0.0002 & 1 & 0.0000 & & 0.0000 & & 0.000 \\
\hline ANTOFAGASTA & 12 & 0.0006 & 3 & 0.0001 & & 0.0000 & & 0.000 \\
\hline ANTWERP & 52,231 & 2.8157 & 103,003 & 2.0165 & 187 & 0.0714 & 1 & 0.006 \\
\hline APIA & 89 & 0.0048 & 21 & 0.0004 & & 0.0000 & & 0.000 \\
\hline ARAWAK CAY & 4 & 0.0002 & 5 & 0.0001 & & 0.0000 & & 0.000 \\
\hline ARGENTIA & 2 & 0.0001 & 186 & 0.0036 & & 0.0000 & & 0.000 \\
\hline ARICA & 70 & 0.0038 & 84 & 0.0016 & & 0.0000 & & 0.000 \\
\hline ASCENSION & & 0.0000 & 50 & 0.0010 & & 0.0000 & & 0.000 \\
\hline ASHDOD & 256 & 0.0138 & 1170 & 0.0229 & & 0.0000 & & 0.000 \\
\hline AUCKLAND & 10,908 & 0.5880 & 6757 & 0.1323 & & 0.0000 & & 0.000 \\
\hline BAHAMAS & & 0.0000 & 4 & 0.0001 & & 0.0000 & & 0.000 \\
\hline BAHRAIN & 14 & 0.0008 & 4 & 0.0001 & & 0.0000 & & 0.000 \\
\hline BALBOA & 7968 & 0.4295 & 22,035 & 0.4314 & 566 & 0.2161 & & 0.000 \\
\hline BANDAR ABBAS & 16 & 0.0009 & 8 & 0.0002 & & 0.0000 & & 0.000 \\
\hline BANDJARMASIN & & 0.0000 & 1 & 0.0000 & & 0.0000 & & 0.000 \\
\hline BANGKOK & 89 & 0.0048 & 265 & 0.0052 & 1 & 0.0004 & & 0.000 \\
\hline BARAHONA & 1 & 0.0001 & & 0.0000 & & 0.0000 & & 0.000 \\
\hline BARCELONA & 14,077 & 0.7589 & 16,016 & 0.3135 & 9 & 0.0034 & & 0.000 \\
\hline
\end{tabular}


PNNL-21088

\begin{tabular}{|c|c|c|c|c|c|c|c|c|}
\hline Foreign Port & $\begin{array}{c}20-\mathrm{ft} \\
\text { Containers }\end{array}$ & $\begin{array}{l}\text { Percent } \\
\text { of Total }\end{array}$ & $\begin{array}{c}40-\mathrm{ft} \\
\text { Containers }\end{array}$ & $\begin{array}{l}\text { Percent } \\
\text { of Total }\end{array}$ & $\begin{array}{c}45-\mathrm{ft} \\
\text { Containers }\end{array}$ & $\begin{array}{l}\text { Percent } \\
\text { of Total }\end{array}$ & Other & $\begin{array}{l}\text { Percent } \\
\text { of Total }\end{array}$ \\
\hline BARRANQUILLA & 1706 & 0.0920 & 1490 & 0.0292 & 27 & 0.0103 & & 0.000 \\
\hline BASSETERRE & 41 & 0.0022 & 20 & 0.0004 & & 0.0000 & & 0.000 \\
\hline BEIHAI & 28 & 0.0015 & 53 & 0.0010 & & 0.0000 & & 0.000 \\
\hline BEIJIAO & & 0.0000 & 3 & 0.0001 & & 0.0000 & & 0.000 \\
\hline BEIRA & & 0.0000 & 1 & 0.0000 & & 0.0000 & & 0.000 \\
\hline BEIRUT & & 0.0000 & 3 & 0.0001 & & 0.0000 & & 0.000 \\
\hline BELAWAN DELI & 30 & 0.0016 & 84 & 0.0016 & & 0.0000 & & 0.000 \\
\hline BELEM & 3 & 0.0002 & 6 & 0.0001 & & 0.0000 & & 0.000 \\
\hline BELFAST & & 0.0000 & 9 & 0.0002 & & 0.0000 & & 0.000 \\
\hline BELIZE CITY & & 0.0000 & 24 & 0.0005 & & 0.0000 & & 0.000 \\
\hline BERMUDA & & 0.0000 & 259 & 0.0051 & & 0.0000 & & 0.000 \\
\hline BILBAO & 33 & 0.0018 & 109 & 0.0021 & & 0.0000 & & 0.000 \\
\hline BIN QASIM & 1 & 0.0001 & 3 & 0.0001 & & 0.0000 & & 0.000 \\
\hline BINTULU & & 0.0000 & 16 & 0.0003 & & 0.0000 & & 0.000 \\
\hline BOCA CHICA & 90 & 0.0049 & 114 & 0.0022 & 1 & 0.0004 & & 0.000 \\
\hline BOMBAY & 3998 & 0.2155 & 2203 & 0.0431 & & 0.0000 & & 0.000 \\
\hline BONAIRE & 24 & 0.0013 & 8 & 0.0002 & & 0.0000 & & 0.000 \\
\hline BRAKE & & 0.0000 & 9 & 0.0002 & & 0.0000 & & 0.000 \\
\hline BREMEN & 15 & 0.0008 & 268 & 0.0052 & & 0.0000 & & 0.000 \\
\hline BREMERHAVEN & 44,844 & 2.4175 & 154,928 & 3.0330 & 2043 & 0.7799 & 4 & 0.023 \\
\hline BRIDGETOWN & 536 & 0.0289 & 96 & 0.0019 & & 0.0000 & & 0.000 \\
\hline BRISBANE & 2131 & 0.1149 & 1212 & 0.0237 & & 0.0000 & & 0.000 \\
\hline BRISTOL & & 0.0000 & 1 & 0.0000 & & 0.0000 & & 0.000 \\
\hline BUENAVENTURA & 242 & 0.0130 & 233 & 0.0046 & & 0.0000 & & 0.000 \\
\hline BUENOS AIRES & 12,259 & 0.6609 & 15,870 & 0.3107 & & 0.0000 & & 0.000 \\
\hline BUKHTA SEVERN & & 0.0000 & 18 & 0.0004 & & 0.0000 & & 0.000 \\
\hline BUKPYUNG & 1 & 0.0001 & & 0.0000 & & 0.0000 & & 0.000 \\
\hline BURGAS & & 0.0000 & 2 & 0.0000 & & 0.0000 & & 0.000 \\
\hline BUSAN & 143,284 & 7.7242 & 348,586 & 6.8242 & 4292 & 1.6384 & & 0.000 \\
\hline CADIZ & 4 & 0.0002 & 11 & 0.0002 & & 0.0000 & & 0.000 \\
\hline CAGAYAN & 1 & 0.0001 & & 0.0000 & & 0.0000 & & 0.000 \\
\hline CAGLIARI & 989 & 0.0533 & 732 & 0.0143 & 2 & 0.0008 & & 0.000 \\
\hline CAICOS ISL & 20 & 0.0011 & & 0.0000 & & 0.0000 & & 0.000 \\
\hline
\end{tabular}


PNNL-21088

\begin{tabular}{|c|c|c|c|c|c|c|c|c|}
\hline Foreign Port & $\begin{array}{c}20-\mathrm{ft} \\
\text { Containers }\end{array}$ & $\begin{array}{l}\text { Percent } \\
\text { of Total }\end{array}$ & $\begin{array}{c}40-\mathrm{ft} \\
\text { Containers }\end{array}$ & $\begin{array}{l}\text { Percent } \\
\text { of Total }\end{array}$ & $\begin{array}{c}45-\mathrm{ft} \\
\text { Containers }\end{array}$ & $\begin{array}{l}\text { Percent } \\
\text { of Total }\end{array}$ & Other & $\begin{array}{l}\text { Percent } \\
\text { of Total }\end{array}$ \\
\hline CALAIS & 150 & 0.0081 & & 0.0000 & & 0.0000 & & 0.000 \\
\hline CALCUTTA & 2 & 0.0001 & 2 & 0.0000 & 1 & 0.0004 & & 0.000 \\
\hline CALDERA & 144 & 0.0078 & 4655 & 0.0911 & & 0.0000 & & 0.000 \\
\hline CALLAO & 2849 & 0.1536 & 2328 & 0.0456 & 2 & 0.0008 & & 0.000 \\
\hline CAP HAITIEN & 12 & 0.0006 & & 0.0000 & & 0.0000 & & 0.000 \\
\hline CAPE TOWN & 2913 & 0.1570 & 3603 & 0.0705 & & 0.0000 & & 0.000 \\
\hline CARTAGENA & 11,203 & 0.6039 & 9815 & 0.1921 & 9 & 0.0034 & & 0.000 \\
\hline CASABLANCA & & 0.0000 & 1 & 0.0000 & & 0.0000 & & 0.000 \\
\hline CASTRIES & 1 & 0.0001 & & 0.0000 & & 0.0000 & & 0.000 \\
\hline CAT CAYS & & 0.0000 & 1 & 0.0000 & & 0.0000 & & 0.000 \\
\hline CATANIA & 9 & 0.0005 & & 0.0000 & & 0.0000 & & 0.000 \\
\hline CAUCEDO & 3100 & 0.1671 & 3235 & 0.0633 & & 0.0000 & & 0.000 \\
\hline CEBU & 1 & 0.0001 & 140 & 0.0027 & & 0.0000 & & 0.000 \\
\hline CHANG SHA & 6 & 0.0003 & 10 & 0.0002 & & 0.0000 & & 0.000 \\
\hline CHENNAI & 97 & 0.0052 & 4 & 0.0001 & & 0.0000 & & 0.000 \\
\hline CHERIBON & 2 & 0.0001 & & 0.0000 & & 0.0000 & & 0.000 \\
\hline CHILE & & 0.0000 & 26 & 0.0005 & & 0.0000 & & 0.000 \\
\hline CHIN WANG TAO & 1 & 0.0001 & 1 & 0.0000 & & 0.0000 & & 0.000 \\
\hline CHINA P & 11 & 0.0006 & 30 & 0.0006 & & 0.0000 & & 0.000 \\
\hline CHITTAGONG & 37 & 0.0020 & 93 & 0.0018 & & 0.0000 & & 0.000 \\
\hline CHIWAN & 13,271 & 0.7154 & 76,538 & 1.4984 & 4742 & 1.8102 & 1139 & 6.668 \\
\hline CHOFU & 11 & 0.0006 & 1 & 0.0000 & & 0.0000 & & 0.000 \\
\hline CHRISTCHURCH & & 0.0000 & 1 & 0.0000 & & 0.0000 & & 0.000 \\
\hline CHRISTIANSTED & 1664 & 0.0897 & 1137 & 0.0223 & 2 & 0.0008 & 8 & 0.047 \\
\hline COCHIN & 345 & 0.0186 & 7 & 0.0001 & 1 & 0.0004 & & 0.000 \\
\hline COLOMBO & 24,704 & 1.3317 & 20,122 & 0.3939 & 624 & 0.2382 & & 0.000 \\
\hline COLON & 24,999 & 1.3477 & 45,675 & 0.8942 & 632 & 0.2413 & & 0.000 \\
\hline CONAKRY & 4 & 0.0002 & 3 & 0.0001 & & 0.0000 & & 0.000 \\
\hline CONSTANZA & 33 & 0.0018 & 202 & 0.0040 & & 0.0000 & & 0.000 \\
\hline COQUIMBO & 29 & 0.0016 & 434 & 0.0085 & & 0.0000 & & 0.000 \\
\hline CORINTO & 247 & 0.0133 & 468 & 0.0092 & & 0.0000 & & 0.000 \\
\hline CORONEL & 6 & 0.0003 & 1016 & 0.0199 & & 0.0000 & & 0.000 \\
\hline CRISTOBAL & 17 & 0.0009 & & 0.0000 & & 0.0000 & & 0.000 \\
\hline
\end{tabular}


PNNL-21088

\begin{tabular}{|c|c|c|c|c|c|c|c|c|}
\hline Foreign Port & $\begin{array}{c}20-\mathrm{ft} \\
\text { Containers }\end{array}$ & $\begin{array}{l}\text { Percent } \\
\text { of Total }\end{array}$ & $\begin{array}{c}40-\mathrm{ft} \\
\text { Containers }\end{array}$ & $\begin{array}{l}\text { Percent } \\
\text { of Total }\end{array}$ & $\begin{array}{c}45-\mathrm{ft} \\
\text { Containers }\end{array}$ & $\begin{array}{l}\text { Percent } \\
\text { of Total }\end{array}$ & Other & $\begin{array}{l}\text { Percent } \\
\text { of Total }\end{array}$ \\
\hline CURACAO & 2 & 0.0001 & & 0.0000 & & 0.0000 & & 0.000 \\
\hline DA NANG & 13 & 0.0007 & 32 & 0.0006 & & 0.0000 & & 0.000 \\
\hline DADRI & & 0.0000 & 1 & 0.0000 & & 0.0000 & & 0.000 \\
\hline DAKAR & 6 & 0.0003 & 15 & 0.0003 & & 0.0000 & & 0.000 \\
\hline DAMIETTA & 924 & 0.0498 & 3430 & 0.0671 & & 0.0000 & & 0.000 \\
\hline DAMMAN & 442 & 0.0238 & 156 & 0.0031 & & 0.0000 & & 0.000 \\
\hline DAR ES SALAAM & 1 & 0.0001 & & 0.0000 & & 0.0000 & & 0.000 \\
\hline DARIEN & 9994 & 0.5388 & 19,896 & 0.3895 & 282 & 0.1076 & & 0.000 \\
\hline DARWIN & 71 & 0.0038 & & 0.0000 & & 0.0000 & & 0.000 \\
\hline DAVAO & & 0.0000 & 15 & 0.0003 & & 0.0000 & & 0.000 \\
\hline DJIBOUTI & 29 & 0.0016 & 75 & 0.0015 & 5 & 0.0019 & 2 & 0.012 \\
\hline DOMINICAN REP & 1 & 0.0001 & & 0.0000 & & 0.0000 & & 0.000 \\
\hline DOUALA & 128 & 0.0069 & 25 & 0.0005 & & 0.0000 & & 0.000 \\
\hline DOVER & 16 & 0.0009 & 30 & 0.0006 & & 0.0000 & & 0.000 \\
\hline DUBAI & 228 & 0.0123 & 95 & 0.0019 & & 0.0000 & & 0.000 \\
\hline DUBLIN & & 0.0000 & 3 & 0.0001 & & 0.0000 & & 0.000 \\
\hline DUNKIRK & 117 & 0.0063 & 433 & 0.0085 & & 0.0000 & & 0.000 \\
\hline DURBAN & 7699 & 0.4150 & 9494 & 0.1859 & & 0.0000 & & 0.000 \\
\hline EL BLUFF & & 0.0000 & 37 & 0.0007 & & 0.0000 & & 0.000 \\
\hline EL DEKHEILA & & 0.0000 & 1 & 0.0000 & & 0.0000 & & 0.000 \\
\hline EL FERROL & & 0.0000 & 18 & 0.0004 & & 0.0000 & & 0.000 \\
\hline ENSENADA & 371 & 0.0200 & 1885 & 0.0369 & 12 & 0.0046 & & 0.000 \\
\hline ESMARALDAS & 1 & 0.0001 & & 0.0000 & & 0.0000 & & 0.000 \\
\hline FANGCHENG & 6 & 0.0003 & 5 & 0.0001 & & 0.0000 & & 0.000 \\
\hline FARIDABAD & 9 & 0.0005 & 20 & 0.0004 & & 0.0000 & 1 & 0.006 \\
\hline FELIXSTOWE & 7478 & 0.4031 & 21,218 & 0.4154 & 1255 & 0.4791 & & 0.000 \\
\hline FOGO & & 0.0000 & 1 & 0.0000 & & 0.0000 & & 0.000 \\
\hline FORTALEZA & 334 & 0.0180 & 350 & 0.0069 & & 0.0000 & & 0.000 \\
\hline FOS & 3766 & 0.2030 & 8786 & 0.1720 & & 0.0000 & & 0.000 \\
\hline FOSHAN & & 0.0000 & 6 & 0.0001 & & 0.0000 & & 0.000 \\
\hline FREDRIKSTAD & & 0.0000 & 1 & 0.0000 & & 0.0000 & & 0.000 \\
\hline FREEPORT & 55,450 & 2.9892 & 62,541 & 1.2243 & 79 & 0.0302 & & 0.000 \\
\hline FREMANTLE & 5 & 0.0003 & & 0.0000 & & 0.0000 & & 0.000 \\
\hline
\end{tabular}


PNNL-21088

\begin{tabular}{|c|c|c|c|c|c|c|c|c|}
\hline Foreign Port & $\begin{array}{c}20-\mathrm{ft} \\
\text { Containers }\end{array}$ & $\begin{array}{l}\text { Percent } \\
\text { of Total }\end{array}$ & $\begin{array}{c}\text { 40-ft } \\
\text { Containers }\end{array}$ & $\begin{array}{l}\text { Percent } \\
\text { of Total }\end{array}$ & $\begin{array}{c}45-\mathrm{ft} \\
\text { Containers }\end{array}$ & $\begin{array}{l}\text { Percent } \\
\text { of Total }\end{array}$ & Other & $\begin{array}{l}\text { Percent } \\
\text { of Total }\end{array}$ \\
\hline FRONTERA & 1 & 0.0001 & & 0.0000 & & 0.0000 & & 0.000 \\
\hline FT DE FRANCE & 28 & 0.0015 & 15 & 0.0003 & & 0.0000 & & 0.000 \\
\hline FUZHOU & 1279 & 0.0689 & 2280 & 0.0446 & 58 & 0.0221 & & 0.000 \\
\hline GDANSK & 164 & 0.0088 & 1 & 0.0000 & & 0.0000 & & 0.000 \\
\hline GDYNIA & 4 & 0.0002 & 9 & 0.0002 & & 0.0000 & & 0.000 \\
\hline GEMLIK & 404 & 0.0218 & 1064 & 0.0208 & & 0.0000 & & 0.000 \\
\hline GENOA & 19,120 & 1.0307 & 21,772 & 0.4262 & & 0.0000 & & 0.000 \\
\hline GEORGETOWN & 202 & 0.0109 & 215 & 0.0042 & & 0.0000 & & 0.000 \\
\hline GIOIA TAURO & 16,055 & 0.8655 & 26,485 & 0.5185 & 231 & 0.0882 & & 0.000 \\
\hline GITMO BAY & 24 & 0.0013 & 215 & 0.0042 & & 0.0000 & & 0.000 \\
\hline GLADSTONE & & 0.0000 & 2 & 0.0000 & & 0.0000 & & 0.000 \\
\hline GOLD RVR & 1 & 0.0001 & & 0.0000 & & 0.0000 & & 0.000 \\
\hline GOTHENBURG & 1168 & 0.0630 & 5561 & 0.1089 & & 0.0000 & & 0.000 \\
\hline GOVERNORS HBR & & 0.0000 & 1 & 0.0000 & & 0.0000 & & 0.000 \\
\hline GRAND TURK & 35 & 0.0019 & 1 & 0.0000 & & 0.0000 & & 0.000 \\
\hline GRANGEMOUTH & 1 & 0.0001 & & 0.0000 & & 0.0000 & & 0.000 \\
\hline GUANGDONG & 33 & 0.0018 & 183 & 0.0036 & & 0.0000 & & 0.000 \\
\hline GUANGZHOU & 89 & 0.0048 & 233 & 0.0046 & & 0.0000 & & 0.000 \\
\hline GUANTA & 8 & 0.0004 & 15 & 0.0003 & & 0.0000 & & 0.000 \\
\hline GUARANAO & 11 & 0.0006 & & 0.0000 & & 0.0000 & & 0.000 \\
\hline GUAYAQUIL & 1007 & 0.0543 & 24,341 & 0.4765 & 10 & 0.0038 & & 0.000 \\
\hline GULF OF MEX & 11 & 0.0006 & & 0.0000 & & 0.0000 & & 0.000 \\
\hline HAIFA & 9369 & 0.5051 & 27,512 & 0.5386 & 13 & 0.0050 & & 0.000 \\
\hline HAIKOU & 2 & 0.0001 & 16 & 0.0003 & & 0.0000 & & 0.000 \\
\hline HAINA & 293 & 0.0158 & 1009 & 0.0198 & 219 & 0.0836 & & 0.000 \\
\hline HAIPHONG & 16 & 0.0009 & 22 & 0.0004 & & 0.0000 & & 0.000 \\
\hline HAKATA & & 0.0000 & 85 & 0.0017 & & 0.0000 & & 0.000 \\
\hline HAKODATE & 11 & 0.0006 & & 0.0000 & & 0.0000 & & 0.000 \\
\hline HALDIA & 3 & 0.0002 & & 0.0000 & & 0.0000 & & 0.000 \\
\hline HALIFAX & 2891 & 0.1558 & 9793 & 0.1917 & 50 & 0.0191 & & 0.000 \\
\hline HAMBURG & 10,318 & 0.5562 & 26,339 & 0.5156 & 52 & 0.0198 & & 0.000 \\
\hline HAMILTON & 364 & 0.0196 & & 0.0000 & 8 & 0.0031 & 4 & 0.023 \\
\hline HANKOW & 34 & 0.0018 & 30 & 0.0006 & & 0.0000 & & 0.000 \\
\hline
\end{tabular}


PNNL-21088

\begin{tabular}{|c|c|c|c|c|c|c|c|c|}
\hline Foreign Port & $\begin{array}{c}20-\mathrm{ft} \\
\text { Containers }\end{array}$ & $\begin{array}{l}\text { Percent } \\
\text { of Total }\end{array}$ & $\begin{array}{c}\text { 40-ft } \\
\text { Containers }\end{array}$ & $\begin{array}{l}\text { Percent } \\
\text { of Total }\end{array}$ & $\begin{array}{c}45-\mathrm{ft} \\
\text { Containers }\end{array}$ & $\begin{array}{l}\text { Percent } \\
\text { of Total }\end{array}$ & Other & $\begin{array}{l}\text { Percent } \\
\text { of Total }\end{array}$ \\
\hline HARBURG & & 0.0000 & 5 & 0.0001 & & 0.0000 & & 0.000 \\
\hline HELGUVIK & 5 & 0.0003 & 105 & 0.0021 & & 0.0000 & & 0.000 \\
\hline HELSINGBORG & & 0.0000 & 2 & 0.0000 & & 0.0000 & & 0.000 \\
\hline HELSINKI & 3 & 0.0002 & & 0.0000 & & 0.0000 & & 0.000 \\
\hline $\mathrm{HO} \mathrm{CHI} \mathrm{MINH}$ & 31 & 0.0017 & 260 & 0.0051 & 41 & 0.0157 & 14 & 0.082 \\
\hline HONDAGUA & 1 & 0.0001 & 2 & 0.0000 & & 0.0000 & & 0.000 \\
\hline HONG KONG & 94,618 & 5.1007 & 417,513 & 8.1735 & 33,541 & 12.8035 & 54 & 0.316 \\
\hline HSINKANG & 29,998 & 1.6171 & 64,137 & 1.2556 & 916 & 0.3497 & 1 & 0.006 \\
\hline HUANGPU & 165 & 0.0089 & 1641 & 0.0321 & & 0.0000 & & 0.000 \\
\hline ILLYICHEVSK & 38 & 0.0020 & 22 & 0.0004 & & 0.0000 & & 0.000 \\
\hline IMBITUBA & 980 & 0.0528 & 226 & 0.0044 & & 0.0000 & & 0.000 \\
\hline INDIA & 2 & 0.0001 & 2 & 0.0000 & & 0.0000 & & 0.000 \\
\hline IQUITOS & 2 & 0.0001 & 14 & 0.0003 & & 0.0000 & & 0.000 \\
\hline ISTANBUL & 634 & 0.0342 & 2185 & 0.0428 & & 0.0000 & & 0.000 \\
\hline ITAGUAI & 37 & 0.0020 & 5 & 0.0001 & & 0.0000 & & 0.000 \\
\hline ITAJAI & 7828 & 0.4220 & 13,911 & 0.2723 & & 0.0000 & & 0.000 \\
\hline IZMIR & 4842 & 0.2610 & 5795 & 0.1134 & 13 & 0.0050 & & 0.000 \\
\hline JAKARTA & 7 & 0.0004 & 45 & 0.0009 & 2 & 0.0008 & & 0.000 \\
\hline JAWAHARLAL NE & 28,480 & 1.5353 & 32,162 & 0.6296 & 111 & 0.0424 & & 0.000 \\
\hline JEBEL ALI & 11,457 & 0.6176 & 3830 & 0.0750 & 65 & 0.0248 & & 0.000 \\
\hline JEDDAH & 981 & 0.0529 & 1971 & 0.0386 & 9 & 0.0034 & & 0.000 \\
\hline JIANGMEN & 1 & 0.0001 & 34 & 0.0007 & & 0.0000 & & 0.000 \\
\hline JIANGYIN & 246 & 0.0133 & 39 & 0.0008 & & 0.0000 & & 0.000 \\
\hline JIUZHOU & 5 & 0.0003 & 35 & 0.0007 & & 0.0000 & & 0.000 \\
\hline JOHORE BAHRU & 64 & 0.0035 & 322 & 0.0063 & 1 & 0.0004 & & 0.000 \\
\hline KAARSTO & 19 & 0.0010 & & 0.0000 & & 0.0000 & & 0.000 \\
\hline KANDLA & 29 & 0.0016 & & 0.0000 & & 0.0000 & & 0.000 \\
\hline KAOHSIUNG & 128,149 & 6.9083 & 317,897 & 6.2234 & 16,344 & 6.2390 & & 0.000 \\
\hline KARACHI & 64 & 0.0035 & 150 & 0.0029 & & 0.0000 & & 0.000 \\
\hline KARATSU & 1 & 0.0001 & & 0.0000 & & 0.0000 & & 0.000 \\
\hline KEELUNG & 4381 & 0.2362 & 15,622 & 0.3058 & 852 & 0.3252 & & 0.000 \\
\hline KIMBE & 1 & 0.0001 & & 0.0000 & & 0.0000 & & 0.000 \\
\hline KINGSTON & 25,240 & 1.3606 & 43,533 & 0.8522 & 306 & 0.1168 & & 0.000 \\
\hline
\end{tabular}


PNNL-21088

\begin{tabular}{|c|c|c|c|c|c|c|c|c|}
\hline Foreign Port & $\begin{array}{c}20-\mathrm{ft} \\
\text { Containers }\end{array}$ & $\begin{array}{l}\text { Percent } \\
\text { of Total }\end{array}$ & $\begin{array}{c}\text { 40-ft } \\
\text { Containers }\end{array}$ & $\begin{array}{l}\text { Percent } \\
\text { of Total }\end{array}$ & $\begin{array}{c}45-\mathrm{ft} \\
\text { Containers }\end{array}$ & $\begin{array}{l}\text { Percent } \\
\text { of Total }\end{array}$ & Other & $\begin{array}{l}\text { Percent } \\
\text { of Total }\end{array}$ \\
\hline KOBE & 22,857 & 1.2322 & 34,198 & 0.6695 & 173 & 0.0660 & & 0.000 \\
\hline KOPER & 2 & 0.0001 & 28 & 0.0005 & & 0.0000 & & 0.000 \\
\hline KOTA KINABALU & & 0.0000 & 12 & 0.0002 & & 0.0000 & & 0.000 \\
\hline KRISTIANSAND & & 0.0000 & 5 & 0.0001 & & 0.0000 & & 0.000 \\
\hline KUCHING & 4 & 0.0002 & & 0.0000 & & 0.0000 & & 0.000 \\
\hline KUMPORT & 1 & 0.0001 & & 0.0000 & & 0.0000 & & 0.000 \\
\hline KUWAIT & 638 & 0.0344 & & 0.0000 & & 0.0000 & & 0.000 \\
\hline KWANGYANG & 10,815 & 0.5830 & 46,142 & 0.9033 & 652 & 0.2489 & & 0.000 \\
\hline KWINANA & & 0.0000 & 2 & 0.0000 & & 0.0000 & & 0.000 \\
\hline LA GUAIRA & 463 & 0.0250 & 347 & 0.0068 & & 0.0000 & & 0.000 \\
\hline LA ROMANA & & 0.0000 & 15 & 0.0003 & & 0.0000 & & 0.000 \\
\hline LA SPEZIA & 35,785 & 1.9291 & 38,039 & 0.7447 & 39 & 0.0149 & & 0.000 \\
\hline LAE & 1 & 0.0001 & & 0.0000 & & 0.0000 & & 0.000 \\
\hline LAEM CHABANG & 28,489 & 1.5358 & 34,447 & 0.6744 & 3611 & 1.3784 & & 0.000 \\
\hline LAGOS & & 0.0000 & 6 & 0.0001 & & 0.0000 & & 0.000 \\
\hline LATAKIA & & 0.0000 & 1 & 0.0000 & & 0.0000 & & 0.000 \\
\hline LAZARO CARDEN & 50 & 0.0027 & 448 & 0.0088 & & 0.0000 & & 0.000 \\
\hline LE HAVRE & 13945 & 0.7518 & 34,099 & 0.6675 & 44 & 0.0168 & & 0.000 \\
\hline LE VERDON & 1 & 0.0001 & & 0.0000 & & 0.0000 & & 0.000 \\
\hline LEGHORN & 17,134 & 0.9237 & 18,789 & 0.3678 & & 0.0000 & & 0.000 \\
\hline LEIXOES & 21 & 0.0011 & 15 & 0.0003 & & 0.0000 & & 0.000 \\
\hline LIANYUNGANG & 125 & 0.0067 & 294 & 0.0058 & & 0.0000 & & 0.000 \\
\hline LIMASSOL & 1 & 0.0001 & 2 & 0.0000 & & 0.0000 & & 0.000 \\
\hline LIMON & & 0.0000 & 1 & 0.0000 & & 0.0000 & & 0.000 \\
\hline LINDEN & 2 & 0.0001 & & 0.0000 & & 0.0000 & & 0.000 \\
\hline LIRQUEN & 14 & 0.0008 & 656 & 0.0128 & & 0.0000 & & 0.000 \\
\hline LISBON & 2442 & 0.1316 & 5366 & 0.1050 & & 0.0000 & & 0.000 \\
\hline LIVERPOOL & 4867 & 0.2624 & 14,569 & 0.2852 & & 0.0000 & & 0.000 \\
\hline LOBITO & 71 & 0.0038 & & 0.0000 & & 0.0000 & & 0.000 \\
\hline LUANDA & 1 & 0.0001 & 1 & 0.0000 & & 0.0000 & & 0.000 \\
\hline LUBA & 29 & 0.0016 & & 0.0000 & & 0.0000 & & 0.000 \\
\hline MADRAS & 117 & 0.0063 & 37 & 0.0007 & & 0.0000 & & 0.000 \\
\hline MADRID & & 0.0000 & 3 & 0.0001 & & 0.0000 & & 0.000 \\
\hline
\end{tabular}


PNNL-21088

\begin{tabular}{|c|c|c|c|c|c|c|c|c|}
\hline Foreign Port & $\begin{array}{c}20-\mathrm{ft} \\
\text { Containers }\end{array}$ & $\begin{array}{l}\text { Percent } \\
\text { of Total }\end{array}$ & $\begin{array}{c}\text { 40-ft } \\
\text { Containers }\end{array}$ & $\begin{array}{l}\text { Percent } \\
\text { of Total }\end{array}$ & $\begin{array}{c}45-\mathrm{ft} \\
\text { Containers }\end{array}$ & $\begin{array}{l}\text { Percent } \\
\text { of Total }\end{array}$ & Other & $\begin{array}{l}\text { Percent } \\
\text { of Total }\end{array}$ \\
\hline MALABO & 7 & 0.0004 & 1 & 0.0000 & & 0.0000 & & 0.000 \\
\hline MALAGA & 66 & 0.0036 & 43 & 0.0008 & 2 & 0.0008 & & 0.000 \\
\hline MALAYSIA & 14 & 0.0008 & 84 & 0.0016 & & 0.0000 & & 0.000 \\
\hline MANAUS & 2 & 0.0001 & 1 & 0.0000 & & 0.0000 & & 0.000 \\
\hline MANILA & 59 & 0.0032 & 237 & 0.0046 & 2 & 0.0008 & & 0.000 \\
\hline MANZANILLO & 7808 & 0.4209 & 23,285 & 0.4558 & & 0.0000 & & 0.000 \\
\hline MARACAIBO & & 0.0000 & & 0.0000 & 1 & 0.0004 & & 0.000 \\
\hline MARSAXLOKK & 1517 & 0.0818 & 652 & 0.0128 & & 0.0000 & & 0.000 \\
\hline MARSEILLE & 181 & 0.0098 & 903 & 0.0177 & & 0.0000 & & 0.000 \\
\hline MELBOURNE & 21,047 & 1.1346 & 7645 & 0.1497 & & 0.0000 & & 0.000 \\
\hline MERCIN & & 0.0000 & 1 & 0.0000 & & 0.0000 & & 0.000 \\
\hline MERSIN & 126 & 0.0068 & 920 & 0.0180 & & 0.0000 & & 0.000 \\
\hline MOIN & 69 & 0.0037 & 5953 & 0.1165 & 43 & 0.0164 & & 0.000 \\
\hline MOJI & & 0.0000 & 3 & 0.0001 & & 0.0000 & & 0.000 \\
\hline MOMBASA & 48 & 0.0026 & & 0.0000 & & 0.0000 & & 0.000 \\
\hline MONFALCONE & 13 & 0.0007 & 2 & 0.0000 & & 0.0000 & & 0.000 \\
\hline MONROVIA & 880 & 0.0474 & & 0.0000 & & 0.0000 & & 0.000 \\
\hline MONTEVIDEO & 463 & 0.0250 & 3713 & 0.0727 & & 0.0000 & & 0.000 \\
\hline MONTOIR & & 0.0000 & 1 & 0.0000 & & 0.0000 & & 0.000 \\
\hline MONTREAL & 98 & 0.0053 & 115 & 0.0023 & & 0.0000 & & 0.000 \\
\hline MORMUGAO & 2 & 0.0001 & & 0.0000 & & 0.0000 & & 0.000 \\
\hline MUARA & 1 & 0.0001 & & 0.0000 & & 0.0000 & & 0.000 \\
\hline MUMBAI & 35 & 0.0019 & 50 & 0.0010 & & 0.0000 & & 0.000 \\
\hline MUNDRA & 3768 & 0.2031 & 4178 & 0.0818 & 44 & 0.0168 & & 0.000 \\
\hline NAGOYA & 14,329 & 0.7725 & 59,875 & 1.1722 & 51 & 0.0195 & 2 & 0.012 \\
\hline NAHA & 25 & 0.0013 & 246 & 0.0048 & 1 & 0.0004 & & 0.000 \\
\hline NAKANOSEKI & 18 & 0.0010 & 1 & 0.0000 & & 0.0000 & & 0.000 \\
\hline NAN HAI & 1 & 0.0001 & 6 & 0.0001 & & 0.0000 & & 0.000 \\
\hline NAN SHA & 249 & 0.0134 & 2937 & 0.0575 & 5 & 0.0019 & & 0.000 \\
\hline NANJING & 16 & 0.0009 & 127 & 0.0025 & 3 & 0.0011 & & 0.000 \\
\hline NANTUNG & 64 & 0.0035 & 93 & 0.0018 & 60 & 0.0229 & & 0.000 \\
\hline NAPIER & 1015 & 0.0547 & 539 & 0.0106 & & 0.0000 & & 0.000 \\
\hline NAPLES & 3246 & 0.1750 & 13,043 & 0.2553 & & 0.0000 & & 0.000 \\
\hline
\end{tabular}


PNNL-21088

\begin{tabular}{|c|c|c|c|c|c|c|c|c|}
\hline Foreign Port & $\begin{array}{c}20-\mathrm{ft} \\
\text { Containers }\end{array}$ & $\begin{array}{l}\text { Percent } \\
\text { of Total }\end{array}$ & $\begin{array}{c}\text { 40-ft } \\
\text { Containers }\end{array}$ & $\begin{array}{l}\text { Percent } \\
\text { of Total }\end{array}$ & $\begin{array}{c}45-\mathrm{ft} \\
\text { Containers }\end{array}$ & $\begin{array}{l}\text { Percent } \\
\text { of Total }\end{array}$ & Other & $\begin{array}{l}\text { Percent } \\
\text { of Total }\end{array}$ \\
\hline NASSAU & 812 & 0.0438 & 1022 & 0.0200 & 31 & 0.0118 & & 0.000 \\
\hline NEW DELHI & 3 & 0.0002 & & 0.0000 & & 0.0000 & & 0.000 \\
\hline $\begin{array}{l}\text { NEW } \\
\text { MANGALORE }\end{array}$ & 33 & 0.0018 & & 0.0000 & & 0.0000 & & 0.000 \\
\hline NEW PLYMOUTH & 633 & 0.0341 & 169 & 0.0033 & & 0.0000 & & 0.000 \\
\hline NEW WESTMINST & 16 & 0.0009 & & 0.0000 & & 0.0000 & & 0.000 \\
\hline NHAVA SHEVA & 48 & 0.0026 & 32 & 0.0006 & & 0.0000 & & 0.000 \\
\hline NINGPO & 35,895 & 1.9350 & 164,551 & 3.2214 & 5562 & 2.1232 & & 0.000 \\
\hline NJARDVIK & 10 & 0.0005 & 379 & 0.0074 & & 0.0000 & & 0.000 \\
\hline NOUMEA & 216 & 0.0116 & 1 & 0.0000 & & 0.0000 & & 0.000 \\
\hline ODDA & 1 & 0.0001 & & 0.0000 & & 0.0000 & & 0.000 \\
\hline ONOMICHI & 1 & 0.0001 & & 0.0000 & & 0.0000 & & 0.000 \\
\hline OPORTO & 9 & 0.0005 & 3 & 0.0001 & & 0.0000 & & 0.000 \\
\hline ORANJESTAD & 29 & 0.0016 & 52 & 0.0010 & & 0.0000 & & 0.000 \\
\hline OSAKA & 6941 & 0.3742 & 13,692 & 0.2680 & & 0.0000 & & 0.000 \\
\hline PAGO PAGO & 7574 & 0.4083 & 194 & 0.0038 & & 0.0000 & & 0.000 \\
\hline PAITA & 21 & 0.0011 & 1180 & 0.0231 & & 0.0000 & & 0.000 \\
\hline PALERMO & 115 & 0.0062 & 99 & 0.0019 & & 0.0000 & & 0.000 \\
\hline PALUA & 9 & 0.0005 & & 0.0000 & & 0.0000 & & 0.000 \\
\hline PANAMA CITY & 7 & 0.0004 & 202 & 0.0040 & & 0.0000 & & 0.000 \\
\hline PANDJANG & 14 & 0.0008 & 33 & 0.0006 & 1 & 0.0004 & & 0.000 \\
\hline PAPEETE & 215 & 0.0116 & 39 & 0.0008 & & 0.0000 & & 0.000 \\
\hline PAPUA & 1 & 0.0001 & & 0.0000 & & 0.0000 & & 0.000 \\
\hline PARADIP & & 0.0000 & 1 & 0.0000 & & 0.0000 & & 0.000 \\
\hline PARAMARIBO & 115 & 0.0062 & 11 & 0.0002 & & 0.0000 & & 0.000 \\
\hline PARANAGUA & 3574 & 0.1927 & 7038 & 0.1378 & 2 & 0.0008 & & 0.000 \\
\hline PARANAM & 268 & 0.0144 & & 0.0000 & & 0.0000 & & 0.000 \\
\hline PARNAIBA & & 0.0000 & 1 & 0.0000 & & 0.0000 & & 0.000 \\
\hline PASIR GUDANG & 2 & 0.0001 & 27 & 0.0005 & & 0.0000 & & 0.000 \\
\hline PECEM & 1946 & 0.1049 & 1280 & 0.0251 & & 0.0000 & & 0.000 \\
\hline PENANG & 89 & 0.0048 & 355 & 0.0069 & & 0.0000 & & 0.000 \\
\hline PHILIPSBURG & 17 & 0.0009 & 18 & 0.0004 & & 0.0000 & & 0.000 \\
\hline PIPAVAV & 63 & 0.0034 & 57 & 0.0011 & & 0.0000 & & 0.000 \\
\hline
\end{tabular}


PNNL-21088

\begin{tabular}{|c|c|c|c|c|c|c|c|c|}
\hline Foreign Port & $\begin{array}{c}20-\mathrm{ft} \\
\text { Containers }\end{array}$ & $\begin{array}{l}\text { Percent } \\
\text { of Total }\end{array}$ & $\begin{array}{c}\text { 40-ft } \\
\text { Containers }\end{array}$ & $\begin{array}{l}\text { Percent } \\
\text { of Total }\end{array}$ & $\begin{array}{c}45-\mathrm{ft} \\
\text { Containers }\end{array}$ & $\begin{array}{l}\text { Percent } \\
\text { of Total }\end{array}$ & Other & $\begin{array}{l}\text { Percent } \\
\text { of Total }\end{array}$ \\
\hline PIRAEUS & 463 & 0.0250 & 2966 & 0.0581 & & 0.0000 & & 0.000 \\
\hline PLYMOUTH & 9 & 0.0005 & 2 & 0.0000 & & 0.0000 & & 0.000 \\
\hline PNT A PIERRE & 1 & 0.0001 & 8 & 0.0002 & & 0.0000 & & 0.000 \\
\hline PNT A PITRE & 14 & 0.0008 & 209 & 0.0041 & & 0.0000 & & 0.000 \\
\hline PNT LISAS & 269 & 0.0145 & 239 & 0.0047 & & 0.0000 & & 0.000 \\
\hline PNT NOIRE & 2 & 0.0001 & 4 & 0.0001 & & 0.0000 & & 0.000 \\
\hline PORTLAND & & 0.0000 & 10 & 0.0002 & & 0.0000 & & 0.000 \\
\hline PORTSMOUTH & 20 & 0.0011 & 12 & 0.0002 & & 0.0000 & & 0.000 \\
\hline POTI & 2 & 0.0001 & & 0.0000 & & 0.0000 & & 0.000 \\
\hline PROGRESO & 62 & 0.0033 & 12,940 & 0.2533 & & 0.0000 & & 0.000 \\
\hline PROVIDENCIALE & 303 & 0.0163 & 43 & 0.0008 & 1 & 0.0004 & & 0.000 \\
\hline PT AU PRINCE & 78 & 0.0042 & 416 & 0.0081 & 1747 & 0.6669 & 5 & 0.029 \\
\hline PT CHALMERS & 5152 & 0.2777 & 1423 & 0.0279 & & 0.0000 & & 0.000 \\
\hline PT COURBET & 1 & 0.0001 & & 0.0000 & & 0.0000 & & 0.000 \\
\hline PT ELIZABETH & 1015 & 0.0547 & 1611 & 0.0315 & & 0.0000 & & 0.000 \\
\hline PT GENTIL & 4 & 0.0002 & & 0.0000 & & 0.0000 & & 0.000 \\
\hline PT HARCOURT & 29 & 0.0016 & 2 & 0.0000 & & 0.0000 & & 0.000 \\
\hline PT KELANG & 2788 & 0.1503 & 12,047 & 0.2358 & 90 & 0.0344 & & 0.000 \\
\hline PT LIMON & 749 & 0.0404 & 29,692 & 0.5813 & 2828 & 1.0795 & 81 & 0.474 \\
\hline PT LOUIS & 16 & 0.0009 & 19 & 0.0004 & & 0.0000 & & 0.000 \\
\hline PT OF SPAIN & 347 & 0.0187 & 606 & 0.0119 & & 0.0000 & & 0.000 \\
\hline PT PURCELL & & 0.0000 & 2 & 0.0000 & & 0.0000 & & 0.000 \\
\hline PT QASIM & 665 & 0.0358 & 890 & 0.0174 & & 0.0000 & & 0.000 \\
\hline PT RHOADES & 120 & 0.0065 & & 0.0000 & & 0.0000 & & 0.000 \\
\hline PT SAID & 1562 & 0.0842 & 1375 & 0.0269 & 1 & 0.0004 & & 0.000 \\
\hline PTO BARRIOS & 391 & 0.0211 & 11,956 & 0.2341 & 257 & 0.0981 & & 0.000 \\
\hline PTO BOLIVAR & & 0.0000 & 115 & 0.0023 & & 0.0000 & & 0.000 \\
\hline PTO CABELLO & 2793 & 0.1506 & 7854 & 0.1538 & 66 & 0.0252 & & 0.000 \\
\hline PTO CABEZAS & 2 & 0.0001 & & 0.0000 & & 0.0000 & & 0.000 \\
\hline PTO CASTILLA & & 0.0000 & 17,294 & 0.3386 & & 0.0000 & & 0.000 \\
\hline PTO CORTES & 2105 & 0.1135 & 15,440 & 0.3023 & 17,545 & 6.6974 & 518 & 3.033 \\
\hline PTO PLATA & 382 & 0.0206 & 2171 & 0.0425 & 1079 & 0.4119 & & 0.000 \\
\hline PULUM BUKUM & & 0.0000 & 1 & 0.0000 & & 0.0000 & & 0.000 \\
\hline
\end{tabular}


PNNL-21088

\begin{tabular}{|c|c|c|c|c|c|c|c|c|}
\hline Foreign Port & $\begin{array}{c}20-\mathrm{ft} \\
\text { Containers }\end{array}$ & $\begin{array}{l}\text { Percent } \\
\text { of Total }\end{array}$ & $\begin{array}{c}\text { 40-ft } \\
\text { Containers }\end{array}$ & $\begin{array}{l}\text { Percent } \\
\text { of Total }\end{array}$ & $\begin{array}{c}45-\mathrm{ft} \\
\text { Containers }\end{array}$ & $\begin{array}{l}\text { Percent } \\
\text { of Total }\end{array}$ & Other & $\begin{array}{l}\text { Percent } \\
\text { of Total }\end{array}$ \\
\hline PUNTA ARENAS & 4 & 0.0002 & 1 & 0.0000 & & 0.0000 & & 0.000 \\
\hline PUNTA MANZANI & 16,594 & 0.8946 & 34,130 & 0.6682 & 713 & 0.2722 & & 0.000 \\
\hline QINGDAO & 47,773 & 2.5754 & 103,273 & 2.0217 & 3906 & 1.4910 & 231 & 1.352 \\
\hline QUETZAL & 1669 & 0.0900 & 4130 & 0.0809 & 226 & 0.0863 & & 0.000 \\
\hline QUEZALTENANGO & 237 & 0.0128 & 658 & 0.0129 & & 0.0000 & & 0.000 \\
\hline QUI NHON & 2 & 0.0001 & 9 & 0.0002 & & 0.0000 & & 0.000 \\
\hline RAMA & & 0.0000 & 1 & 0.0000 & & 0.0000 & & 0.000 \\
\hline RANGOON & 1 & 0.0001 & 1 & 0.0000 & & 0.0000 & & 0.000 \\
\hline RECIFE & 4 & 0.0002 & 50 & 0.0010 & & 0.0000 & & 0.000 \\
\hline REYKJAVIK & 239 & 0.0129 & 1290 & 0.0253 & 1 & 0.0004 & & 0.000 \\
\hline RICHARDS BAY & 6 & 0.0003 & & 0.0000 & & 0.0000 & & 0.000 \\
\hline RIO D JANEIRO & 10,609 & 0.5719 & 2196 & 0.0430 & & 0.0000 & & 0.000 \\
\hline RIO GRD DO SU & 4248 & 0.2290 & 9355 & 0.1831 & & 0.0000 & & 0.000 \\
\hline ROADTOWN & 1 & 0.0001 & & 0.0000 & & 0.0000 & & 0.000 \\
\hline RONGQI & & 0.0000 & 5 & 0.0001 & & 0.0000 & & 0.000 \\
\hline ROSARITO & 2 & 0.0001 & & 0.0000 & & 0.0000 & & 0.000 \\
\hline ROSEAU & 40 & 0.0022 & 5 & 0.0001 & & 0.0000 & & 0.000 \\
\hline ROSTOCK & & 0.0000 & 1 & 0.0000 & & 0.0000 & & 0.000 \\
\hline ROTTERDAM & 38,443 & 2.0724 & 123,913 & 2.4258 & 6549 & 2.4999 & & 0.000 \\
\hline$S$ PEDRO D MAC & & 0.0000 & 1 & 0.0000 & & 0.0000 & & 0.000 \\
\hline SAIGON & 145 & 0.0078 & 1412 & 0.0276 & 10 & 0.0038 & & 0.000 \\
\hline SAIPAN & & 0.0000 & 1 & 0.0000 & & 0.0000 & & 0.000 \\
\hline SALALAH & 12,127 & 0.6537 & 30,459 & 0.5963 & 639 & 0.2439 & & 0.000 \\
\hline SALVADOR & 3352 & 0.1807 & 7489 & 0.1466 & & 0.0000 & & 0.000 \\
\hline SAMARINDA & & 0.0000 & 8 & 0.0002 & & 0.0000 & & 0.000 \\
\hline SAN ANDRES & & 0.0000 & 50 & 0.0010 & & 0.0000 & & 0.000 \\
\hline SAN ANTONIO & 5590 & 0.3013 & 13,033 & 0.2551 & & 0.0000 & & 0.000 \\
\hline SAN CRISTOBAL & & 0.0000 & 1 & 0.0000 & & 0.0000 & & 0.000 \\
\hline SAN JOSE & & 0.0000 & 1 & 0.0000 & & 0.0000 & & 0.000 \\
\hline SAN JUAN & 8207 & 0.4424 & 28,206 & 0.5522 & 16,443 & 6.2767 & 12507 & 73.222 \\
\hline SAN PEDRO & & 0.0000 & 168 & 0.0033 & & 0.0000 & & 0.000 \\
\hline SAN PEDRO SUL & 4 & 0.0002 & 5 & 0.0001 & & 0.0000 & & 0.000 \\
\hline SAN VICENTE & 503 & 0.0271 & 11,398 & 0.2231 & 1 & 0.0004 & & 0.000 \\
\hline
\end{tabular}


PNNL-21088

\begin{tabular}{|c|c|c|c|c|c|c|c|c|}
\hline Foreign Port & $\begin{array}{c}20-\mathrm{ft} \\
\text { Containers }\end{array}$ & $\begin{array}{l}\text { Percent } \\
\text { of Total }\end{array}$ & $\begin{array}{c}\text { 40-ft } \\
\text { Containers }\end{array}$ & $\begin{array}{l}\text { Percent } \\
\text { of Total }\end{array}$ & $\begin{array}{c}45-\mathrm{ft} \\
\text { Containers }\end{array}$ & $\begin{array}{l}\text { Percent } \\
\text { of Total }\end{array}$ & Other & $\begin{array}{l}\text { Percent } \\
\text { of Total }\end{array}$ \\
\hline SANDY PNT & 45 & 0.0024 & 102 & 0.0020 & & 0.0000 & & 0.000 \\
\hline SANTA MARTA & 6 & 0.0003 & 7069 & 0.1384 & & 0.0000 & & 0.000 \\
\hline SANTIAGO & 8 & 0.0004 & 110 & 0.0022 & & 0.0000 & & 0.000 \\
\hline SANTOS & 48,775 & 2.6294 & 35,853 & 0.7019 & 1 & 0.0004 & & 0.000 \\
\hline SAO FRAN DO S & 12,752 & 0.6874 & 11,847 & 0.2319 & & 0.0000 & & 0.000 \\
\hline SEMARANG & 36 & 0.0019 & 399 & 0.0078 & 2 & 0.0008 & & 0.000 \\
\hline SENDAI & 435 & 0.0235 & 5674 & 0.1111 & & 0.0000 & & 0.000 \\
\hline SEPETIBA BAY & 6709 & 0.3617 & 3508 & 0.0687 & & 0.0000 & & 0.000 \\
\hline SHANGHAI & 159,507 & 8.5987 & 594,462 & 11.6376 & 26,933 & 10.2811 & 173 & 1.013 \\
\hline SHANTOU & 2 & 0.0001 & 27 & 0.0005 & & 0.0000 & & 0.000 \\
\hline SHEKOU & 6996 & 0.3771 & 75,028 & 1.4688 & 4429 & 1.6907 & & 0.000 \\
\hline SHELBURNE & 1 & 0.0001 & 15 & 0.0003 & & 0.0000 & & 0.000 \\
\hline SHENZHEN & 1 & 0.0001 & & 0.0000 & & 0.0000 & & 0.000 \\
\hline SHIMIZU & 912 & 0.0492 & 10,457 & 0.2047 & 1 & 0.0004 & & 0.000 \\
\hline SHUAIBA & 3 & 0.0002 & 3 & 0.0001 & & 0.0000 & & 0.000 \\
\hline SIALKOT & 1 & 0.0001 & 2 & 0.0000 & & 0.0000 & & 0.000 \\
\hline SIHANOUKVILLE & 20 & 0.0011 & 38 & 0.0007 & 7 & 0.0027 & & 0.000 \\
\hline SINES & 1572 & 0.0847 & 2970 & 0.0581 & & 0.0000 & & 0.000 \\
\hline SINGAPORE & 71,095 & 3.8326 & 146,296 & 2.8640 & 9108 & 3.4768 & & 0.000 \\
\hline SLITE & & 0.0000 & 1 & 0.0000 & & 0.0000 & & 0.000 \\
\hline SONGKHLA & 32 & 0.0017 & 58 & 0.0011 & & 0.0000 & & 0.000 \\
\hline SOUTHAMPTON & 3439 & 0.1854 & 8453 & 0.1655 & 68 & 0.0260 & & 0.000 \\
\hline SOYO & 35 & 0.0019 & & 0.0000 & & 0.0000 & & 0.000 \\
\hline ST CROIX & 1 & 0.0001 & 4 & 0.0001 & & 0.0000 & 1 & 0.006 \\
\hline ST GEORGE & 22 & 0.0012 & 3 & 0.0001 & & 0.0000 & & 0.000 \\
\hline ST JOHN & 1282 & 0.0691 & 7290 & 0.1427 & 2 & 0.0008 & & 0.000 \\
\hline ST JOHNS & 64 & 0.0035 & 9 & 0.0002 & & 0.0000 & & 0.000 \\
\hline ST LUCIA & 34 & 0.0018 & 16 & 0.0003 & & 0.0000 & & 0.000 \\
\hline ST MAARTEN & 75 & 0.0040 & 46 & 0.0009 & 1 & 0.0004 & & 0.000 \\
\hline ST NICOLAS & 53 & 0.0029 & 7 & 0.0001 & & 0.0000 & & 0.000 \\
\hline ST PETERSBURG & 68 & 0.0037 & 40 & 0.0008 & & 0.0000 & & 0.000 \\
\hline ST PIERRE & & 0.0000 & 2 & 0.0000 & & 0.0000 & & 0.000 \\
\hline ST THOMAS & 399 & 0.0215 & 1034 & 0.0202 & 30 & 0.0115 & 30 & 0.176 \\
\hline
\end{tabular}


PNNL-21088

\begin{tabular}{|c|c|c|c|c|c|c|c|c|}
\hline Foreign Port & $\begin{array}{c}20-\mathrm{ft} \\
\text { Containers }\end{array}$ & $\begin{array}{l}\text { Percent } \\
\text { of Total }\end{array}$ & $\begin{array}{c}\text { 40-ft } \\
\text { Containers }\end{array}$ & $\begin{array}{l}\text { Percent } \\
\text { of Total }\end{array}$ & $\begin{array}{c}45-\mathrm{ft} \\
\text { Containers }\end{array}$ & $\begin{array}{l}\text { Percent } \\
\text { of Total }\end{array}$ & Other & $\begin{array}{l}\text { Percent } \\
\text { of Total }\end{array}$ \\
\hline STO DOMINGO & 749 & 0.0404 & 2181 & 0.0427 & 1462 & 0.5581 & 2 & 0.012 \\
\hline STO TOMAS & 2488 & 0.1341 & 9414 & 0.1843 & 5613 & 2.1426 & 219 & 1.282 \\
\hline STOCKHOLM & 5 & 0.0003 & 7 & 0.0001 & & 0.0000 & & 0.000 \\
\hline SUAPE & 2208 & 0.1190 & 4124 & 0.0807 & & 0.0000 & & 0.000 \\
\hline SUPE & 1 & 0.0001 & & 0.0000 & & 0.0000 & & 0.000 \\
\hline SURABAYA & 172 & 0.0093 & 427 & 0.0084 & & 0.0000 & & 0.000 \\
\hline SUVA & 4299 & 0.2318 & 179 & 0.0035 & & 0.0000 & & 0.000 \\
\hline SWEDEN & 11 & 0.0006 & & 0.0000 & & 0.0000 & & 0.000 \\
\hline SYDNEY & 5891 & 0.3176 & 2910 & 0.0570 & & 0.0000 & & 0.000 \\
\hline SZCZECIN & 1 & 0.0001 & & 0.0000 & & 0.0000 & & 0.000 \\
\hline T J PANDAN & 2 & 0.0001 & & 0.0000 & & 0.0000 & & 0.000 \\
\hline T J PELEPAS & 7857 & 0.4236 & 22,501 & 0.4405 & 556 & 0.2122 & & 0.000 \\
\hline T J PRIOK & 350 & 0.0189 & 463 & 0.0091 & 3 & 0.0011 & & 0.000 \\
\hline TAICHUNG & 3 & 0.0002 & 27 & 0.0005 & & 0.0000 & & 0.000 \\
\hline TAIPEI & & 0.0000 & 1 & 0.0000 & & 0.0000 & & 0.000 \\
\hline TAIWAN & & 0.0000 & 1 & 0.0000 & & 0.0000 & & 0.000 \\
\hline TAKORADI & 46 & 0.0025 & 528 & 0.0103 & & 0.0000 & & 0.000 \\
\hline TALCAHUANO & & 0.0000 & 1 & 0.0000 & & 0.0000 & & 0.000 \\
\hline TAMPICO & 3701 & 0.1995 & 6015 & 0.1178 & & 0.0000 & & 0.000 \\
\hline TANJONG & 11 & 0.0006 & 8 & 0.0002 & & 0.0000 & & 0.000 \\
\hline TARANTO & 425 & 0.0229 & 329 & 0.0064 & & 0.0000 & & 0.000 \\
\hline TAURANGA & 15,569 & 0.8393 & 7513 & 0.1471 & & 0.0000 & & 0.000 \\
\hline TEGUCIGALPA & & 0.0000 & 1 & 0.0000 & & 0.0000 & & 0.000 \\
\hline TEMA & 32 & 0.0017 & 253 & 0.0050 & & 0.0000 & & 0.000 \\
\hline TERCEIRA ISL & 15 & 0.0008 & 36 & 0.0007 & 1 & 0.0004 & & 0.000 \\
\hline THAMESPORT & 3102 & 0.1672 & 6600 & 0.1292 & 25 & 0.0095 & 1 & 0.006 \\
\hline THESSALONIKI & 1 & 0.0001 & 57 & 0.0011 & & 0.0000 & & 0.000 \\
\hline TIANJIN & 3688 & 0.1988 & 5579 & 0.1092 & 107 & 0.0408 & & 0.000 \\
\hline TIJUANA & & 0.0000 & 1 & 0.0000 & & 0.0000 & & 0.000 \\
\hline TILBURY & 676 & 0.0364 & 914 & 0.0179 & 16 & 0.0061 & & 0.000 \\
\hline TIMARU & 1269 & 0.0684 & 897 & 0.0176 & & 0.0000 & & 0.000 \\
\hline TINIAN & & 0.0000 & 1 & 0.0000 & & 0.0000 & & 0.000 \\
\hline TOAMASINA & & 0.0000 & 1 & 0.0000 & & 0.0000 & & 0.000 \\
\hline
\end{tabular}


PNNL-21088

\begin{tabular}{|c|c|c|c|c|c|c|c|c|}
\hline Foreign Port & $\begin{array}{c}20-\mathrm{ft} \\
\text { Containers }\end{array}$ & $\begin{array}{l}\text { Percent } \\
\text { of Total }\end{array}$ & $\begin{array}{c}40-\mathrm{ft} \\
\text { Containers }\end{array}$ & $\begin{array}{l}\text { Percent } \\
\text { of Total }\end{array}$ & $\begin{array}{c}45-\mathrm{ft} \\
\text { Containers }\end{array}$ & $\begin{array}{l}\text { Percent } \\
\text { of Total }\end{array}$ & Other & $\begin{array}{l}\text { Percent } \\
\text { of Total }\end{array}$ \\
\hline TOKYO & 26,682 & 1.4384 & 84,271 & 1.6497 & 555 & 0.2119 & & 0.000 \\
\hline TORONTO & & 0.0000 & 53 & 0.0010 & & 0.0000 & & 0.000 \\
\hline TRAPANI & 1 & 0.0001 & & 0.0000 & & 0.0000 & & 0.000 \\
\hline TRENTO & 9 & 0.0005 & 20 & 0.0004 & & 0.0000 & & 0.000 \\
\hline TRIESTE & 10 & 0.0005 & 5 & 0.0001 & & 0.0000 & & 0.000 \\
\hline TUBARAO & 2 & 0.0001 & & 0.0000 & & 0.0000 & & 0.000 \\
\hline TUNIS & & 0.0000 & 2 & 0.0000 & & 0.0000 & & 0.000 \\
\hline TURBO & & 0.0000 & 239 & 0.0047 & & 0.0000 & & 0.000 \\
\hline TURKEY & 1 & 0.0001 & 15 & 0.0003 & & 0.0000 & & 0.000 \\
\hline TUTICORIN & 503 & 0.0271 & 338 & 0.0066 & & 0.0000 & & 0.000 \\
\hline UDDEVALLA & 2 & 0.0001 & 7 & 0.0001 & & 0.0000 & & 0.000 \\
\hline VALENCIA & 32,985 & 1.7782 & 20,080 & 0.3931 & 25 & 0.0095 & & 0.000 \\
\hline VALLETTA & 20 & 0.0011 & 12 & 0.0002 & & 0.0000 & & 0.000 \\
\hline VALPARAISO & 497 & 0.0268 & 1707 & 0.0334 & & 0.0000 & & 0.000 \\
\hline VANCOUVER & 264 & 0.0142 & 924 & 0.0181 & & 0.0000 & & 0.000 \\
\hline VANUATU & 56 & 0.0030 & & 0.0000 & & 0.0000 & & 0.000 \\
\hline VARNA & 2 & 0.0001 & 18 & 0.0004 & & 0.0000 & & 0.000 \\
\hline VENICE & 8 & 0.0004 & 21 & 0.0004 & & 0.0000 & & 0.000 \\
\hline VERA CRUZ & 4173 & 0.2250 & 4266 & 0.0835 & 1 & 0.0004 & & 0.000 \\
\hline VIEUX FORT & 8 & 0.0004 & 6 & 0.0001 & & 0.0000 & & 0.000 \\
\hline VIGO & 1 & 0.0001 & 1 & 0.0000 & & 0.0000 & & 0.000 \\
\hline VIIPURI & 1 & 0.0001 & 4 & 0.0001 & & 0.0000 & & 0.000 \\
\hline VISHAKHAPATNA & 7 & 0.0004 & & 0.0000 & & 0.0000 & & 0.000 \\
\hline VITORIA & 10,642 & 0.5737 & 301 & 0.0059 & & 0.0000 & & 0.000 \\
\hline WILLEMSTAD & 15 & 0.0008 & 2 & 0.0000 & & 0.0000 & & 0.000 \\
\hline WUHU & & 0.0000 & 2 & 0.0000 & & 0.0000 & & 0.000 \\
\hline XIAMEN & 14,644 & 0.7894 & 86,427 & 1.6920 & 6115 & 2.3343 & 42 & 0.246 \\
\hline YANGZHOU & 5 & 0.0003 & 19 & 0.0004 & & 0.0000 & & 0.000 \\
\hline YANTAI & 112 & 0.0060 & 452 & 0.0088 & & 0.0000 & & 0.000 \\
\hline YANTIAN & 69,585 & 3.7512 & 778,866 & 15.2476 & 75,824 & 28.9441 & 2040 & 11.943 \\
\hline YOKKAICHI & 34 & 0.0018 & & 0.0000 & & 0.0000 & & 0.000 \\
\hline YOKOHAMA & 13,991 & 0.7542 & 42,993 & 0.8417 & 187 & 0.0714 & & 0.000 \\
\hline YOSU & 16 & 0.0009 & & 0.0000 & & 0.0000 & & 0.000 \\
\hline
\end{tabular}


PNNL-21088

\begin{tabular}{|c|c|c|c|c|c|c|c|c|}
\hline Foreign Port & $\begin{array}{c}20-\mathrm{ft} \\
\text { Containers }\end{array}$ & $\begin{array}{l}\text { Percent } \\
\text { of Total }\end{array}$ & $\begin{array}{c}40-\mathrm{ft} \\
\text { Containers }\end{array}$ & $\begin{array}{l}\text { Percent } \\
\text { of Total }\end{array}$ & $\begin{array}{c}45-\mathrm{ft} \\
\text { Containers }\end{array}$ & $\begin{array}{l}\text { Percent } \\
\text { of Total }\end{array}$ & Other & $\begin{array}{l}\text { Percent } \\
\text { of Total }\end{array}$ \\
\hline YUCATAN & 2 & 0.0001 & 44 & 0.0009 & & 0.0000 & & 0.000 \\
\hline ZEEBRUGGE & 2 & 0.0001 & 21 & 0.0004 & 21 & 0.0080 & & 0.000 \\
\hline ZHANGJIAGANG & 127 & 0.0068 & 80 & 0.0016 & & 0.0000 & & 0.000 \\
\hline ZHONGSHAN & 12 & 0.0006 & 120 & 0.0023 & & 0.0000 & & 0.000 \\
\hline ZHUHAI & 1 & 0.0001 & 9 & 0.0002 & & 0.0000 & & 0.000 \\
\hline
\end{tabular}


PNNL-21088

\section{Appendix B: List of Shipping Container Distribution Based on 2-Digit Harmonized System Commodity Codes}

This appendix contains the list of the 2-digit harmonized system commodity codes and their associated number of containers shipped to the US in 2006. Containers sized 20, 40, and $45 \mathrm{ft}$ are listed separately. Other containers sizes (e.g., $48 \mathrm{ft}, 53 \mathrm{ft}$, etc.) are listed in a combined Other category. Included is a brief description for each 2-digit commodity code. 
PNNL-21088

\begin{tabular}{|c|c|c|c|c|c|}
\hline HS Code & Description & $\begin{array}{c}20-\mathrm{ft} \\
\text { Containers }\end{array}$ & $\begin{array}{c}40-\mathrm{ft} \\
\text { Containers }\end{array}$ & $\begin{array}{c}45-\mathrm{ft} \\
\text { Containers }\end{array}$ & Other \\
\hline 0 & Household Goods & 49,895 & 199,852 & 12,032 & 1546 \\
\hline 1 & Live Animals & 13 & 104 & 74 & 0 \\
\hline 2 & Meat \& Edible Meat Offal & 25,379 & 15,986 & 36 & 0 \\
\hline 3 & Fish \& Crustaceans & 7994 & 77,222 & 25 & 0 \\
\hline 4 & Dairy, Eggs, Honey \& Edible Products & 11,271 & 9276 & 86 & 19 \\
\hline 5 & Products of Animal Origin & 867 & 2239 & 47 & 0 \\
\hline 6 & Live Trees \& Other Plants & 401 & 5719 & 138 & 0 \\
\hline 7 & Edible Vegetables & 7965 & 37,402 & 147 & 7 \\
\hline 8 & Edible Fruits \& Nuts, Peel of Citrus/Melons & 14,100 & 136,467 & 54 & 0 \\
\hline 9 & Coffee, Tea, Mate \& Spices & 58,653 & 17,140 & 60 & 6 \\
\hline 10 & Cereals & 19,659 & 2228 & 470 & 5 \\
\hline 11 & Milling Industry Products & 5207 & 8536 & 4 & 0 \\
\hline 12 & $\begin{array}{l}\text { Oil Seeds, Miscellaneous Grains, Medicinal } \\
\text { Plants \& Straw }\end{array}$ & 8653 & 9075 & 45 & 1 \\
\hline 13 & Lac, Gum, Resins, etc. & 5923 & 1488 & 1 & 0 \\
\hline 14 & Vegetable Pailting Materials & 158 & 968 & 24 & 0 \\
\hline 15 & Animal or Vegetable Fats, Oils \& Waxes & 7400 & 8308 & 21 & 0 \\
\hline 16 & $\begin{array}{l}\text { Edible Preparations of Meat, Fish Crustaceans, } \\
\text { etc. }\end{array}$ & 19,455 & 6769 & 18 & 1 \\
\hline 17 & Sugars \& Sugar Confectionery & 9486 & 11,262 & 309 & 29 \\
\hline 18 & Cocoa \& Cocoa Preparations & 8056 & 11,245 & 10 & 3 \\
\hline 19 & Preparations of Cereal, Flour, Starch, or Milk & 3878 & 28,856 & 344 & 232 \\
\hline 20 & Preparations of Vegetables, Fruits, Nuts, etc. & 71,182 & 30,497 & 303 & 9 \\
\hline 21 & Miscellaneous Edible Preparations & 13,184 & 21,418 & 1362 & 303 \\
\hline 22 & Beverages, Spirits \& Vinegar & 53,850 & 155,516 & 991 & 114 \\
\hline 23 & Residues from Food Industries \& Animal Feed & 3329 & 3551 & 21 & 13 \\
\hline 24 & Tobacco \& Manufactured Tobacco Substitues & 304 & 11,690 & 392 & 94 \\
\hline 25 & Salt, Sulphur, Earth \& Stone, Lime \& Cement & 62,985 & 9039 & 68 & 3 \\
\hline 26 & Ores Slag \& Ash & 5258 & 689 & 5 & 0 \\
\hline 27 & $\begin{array}{l}\text { Mineral Fuels, Oils, Waxes \& Bituminous } \\
\text { Substitutes }\end{array}$ & 6115 & 6386 & 65 & 2 \\
\hline
\end{tabular}


PNNL-21088

\begin{tabular}{|c|c|c|c|c|c|}
\hline HS Code & Description & $\begin{array}{c}\text { 20-ft } \\
\text { Containers }\end{array}$ & $\begin{array}{l}\text { 40-ft } \\
\text { Containers }\end{array}$ & $\begin{array}{l}\text { 45-ft } \\
\text { Containers }\end{array}$ & Other \\
\hline 28 & $\begin{array}{l}\text { Inorganic Chemicals, Organic/Inorganic } \\
\text { Compounds of Precious Metals, Isotopes }\end{array}$ & 49,603 & 21,757 & 61 & 4 \\
\hline 29 & Organic Chemicals & 63,957 & 24,759 & 39 & 22 \\
\hline 30 & Pharmaceutical Products & 1087 & 9206 & 2961 & 635 \\
\hline 31 & Fertilizers & 3082 & 2681 & 0 & 0 \\
\hline 32 & $\begin{array}{l}\text { Tanning or Dyeing Extracts, Dyes, Pigments, } \\
\text { Paints \& Varnishes, Putty \& Inks }\end{array}$ & 9497 & 8944 & 68 & 10 \\
\hline 33 & $\begin{array}{l}\text { Oils \& Resinoids, Perfumery, Cosmetic or Toilet } \\
\text { Preparations }\end{array}$ & 5316 & 13,167 & 1016 & 429 \\
\hline 34 & $\begin{array}{l}\text { Soaps, Waxes, Scouring Products, Candles, } \\
\text { Modeling Pastes, Dental Waxes }\end{array}$ & 4781 & 12,547 & 338 & 13 \\
\hline 35 & $\begin{array}{l}\text { Albuminoidal Substitutes, Starches, Glues, } \\
\text { Enzymes }\end{array}$ & 6028 & 6245 & 52 & 1 \\
\hline 36 & Explosives, Matches, Pyrotechnic Products & 195 & 8044 & 11 & 2 \\
\hline 37 & Photographic or Cinematographic Goods & 973 & 7535 & 12 & 1 \\
\hline 38 & Miscellaneous Chemical Products & 18,515 & 13,521 & 604 & 109 \\
\hline 39 & Plastics \& Articles Thereof & 93,919 & 233,330 & 7143 & 1132 \\
\hline 40 & Rubbers \& Articles Thereof & 34,343 & 222,514 & 6805 & 1045 \\
\hline 41 & Raw Hides, Skins \& Leather & 1029 & 2240 & 62 & 3 \\
\hline 42 & $\begin{array}{l}\text { Articles or Leather, Saddlery \& Harness, Travel } \\
\text { Goods, Handbags, Articles of Gut }\end{array}$ & 9991 & 80,695 & 7676 & 36 \\
\hline 43 & Furskins \& Artificial Fur & 65 & 505 & 29 & 0 \\
\hline 44 & Wood \& Articles of Wood, Wood Charcoal & 37,405 & 241,219 & 4850 & 995 \\
\hline 45 & Cork \& Articles of Cork & 180 & 1510 & 13 & 0 \\
\hline 46 & $\begin{array}{l}\text { Manufactures of Straw, Esparto, or Other } \\
\text { Plaiting Materials, Basketware \& Wickerwork }\end{array}$ & 2717 & 19,492 & 1758 & 35 \\
\hline 47 & Pulp of Wood, Waste \& Scrap of Paper & 2226 & 5387 & 49 & 161 \\
\hline 48 & Paper \& Paperboard, Articles of Paper Pulp & 72,959 & 110,147 & 3171 & 192 \\
\hline 49 & $\begin{array}{l}\text { Printed Books, Newspapers, Pictures, } \\
\text { Manuscripts, Typescripts \& Plans }\end{array}$ & 5287 & 13,780 & 335 & 16 \\
\hline 50 & Silk, Including Yarns \& Woven Fabrics Thereof & 42 & 79 & 4 & 0 \\
\hline 51 & $\begin{array}{l}\text { Wool \& Fine or Coarse Animal Hair, Including } \\
\text { Yarns \& Woven Fabrics Thereof }\end{array}$ & 482 & 1031 & 26 & 0 \\
\hline 52 & Cotton, including Yarns \& Woven Fabrics & 6062 & 34,300 & 1395 & 112 \\
\hline
\end{tabular}


PNNL-21088

\begin{tabular}{|c|c|c|c|c|c|}
\hline HS Code & Description & $\begin{array}{c}20-\mathrm{ft} \\
\text { Containers }\end{array}$ & $\begin{array}{c}40-\mathrm{ft} \\
\text { Containers }\end{array}$ & $\begin{array}{c}45-\mathrm{ft} \\
\text { Containers }\end{array}$ & Other \\
\hline & Thereof & & & & \\
\hline 53 & $\begin{array}{l}\text { Vegetable Textile Fibers NESOI, Yarns \& Woven } \\
\text { etc. }\end{array}$ & 1269 & 3958 & 16 & 0 \\
\hline 54 & $\begin{array}{l}\text { Man-Made Filaments, Including Yarns \& Woven } \\
\text { etc. }\end{array}$ & 2667 & 17,837 & 340 & 0 \\
\hline 55 & Man-Made Staple Fibers, Including Yarns etc. & 491 & 19,326 & 42 & 0 \\
\hline 56 & $\begin{array}{l}\text { Wadding, Felt \& Nonwovens, Special Yarns, } \\
\text { Twine, Cordage, Ropes, Cables \& Articles }\end{array}$ & 1251 & 14,019 & 377 & 2 \\
\hline 57 & Carpets \& Other Textile Floor Coverings & 3182 & 14,939 & 609 & 0 \\
\hline 58 & Special Woven Fabrics, Tufted Textiles, Lace & 708 & 3321 & 534 & 0 \\
\hline 59 & $\begin{array}{l}\text { Impregnated, Coated, Covered, or Laminated } \\
\text { Textile Products, Textile Products for Industrial } \\
\text { Use }\end{array}$ & 2206 & 5632 & 47 & 2 \\
\hline 60 & Knitted or Crocheted Fabrics & 569 & 2950 & 209 & 0 \\
\hline 61 & $\begin{array}{l}\text { Articles of Apparel \& Clothing Accessories - } \\
\text { Knitted or Crocheted }\end{array}$ & 9790 & 49,978 & 9260 & 60 \\
\hline 62 & $\begin{array}{l}\text { Articles of Apparel \& Clothing Accessories - Not } \\
\text { Knitted or Crocheted }\end{array}$ & 28,517 & 137,033 & 33,458 & 1265 \\
\hline 63 & $\begin{array}{l}\text { Made-Up Textile Articles NESOI, Needlecraft } \\
\text { Set, Worn Clothing, Rags }\end{array}$ & 10,288 & 78,110 & 5109 & 43 \\
\hline 64 & Footwear, Gaiters \& the Like & 11,521 & 83,181 & 16,303 & 451 \\
\hline 65 & Headgear \& Other Parts & 1735 & 7357 & 695 & 1 \\
\hline 66 & $\begin{array}{l}\text { Umbrellas, Sun Umbrellas, Walking-Sticks, } \\
\text { Whips, Riding-Crops \& Parts }\end{array}$ & 1053 & 3431 & 144 & 0 \\
\hline 67 & $\begin{array}{l}\text { Prepared Feathers, Human Hair \& Articles } \\
\text { Thereof, Artificial Flowers }\end{array}$ & 799 & 14347 & 1857 & 1 \\
\hline 68 & $\begin{array}{l}\text { Articles of Stone, Plaster, Cement, Asbestos, } \\
\text { Mica, or Similar Materials }\end{array}$ & 73,199 & 12,457 & 173 & 5 \\
\hline 69 & Ceramic Products & 143,535 & 81,997 & 3138 & 12 \\
\hline 70 & Glass \& Glassware & 21,191 & 60,693 & 1645 & 66 \\
\hline 71 & $\begin{array}{l}\text { Pearls, Stones, Precious Metals, Imitation } \\
\text { Jewelery, Coins }\end{array}$ & 540 & 1832 & 247 & 8 \\
\hline 72 & Iron \& Steel & 50,033 & 19,320 & 361 & 21 \\
\hline 73 & Articles of Iron or Steel & 162,247 & 161,258 & 11,397 & 235 \\
\hline 74 & Copper \& Articles Thereof & 8723 & 11461 & 203 & 109 \\
\hline
\end{tabular}


PNNL-21088

\begin{tabular}{|c|c|c|c|c|c|}
\hline HS Code & Description & $\begin{array}{l}20-\mathrm{ft} \\
\text { Containers }\end{array}$ & $\begin{array}{c}40-\mathrm{ft} \\
\text { Containers }\end{array}$ & $\begin{array}{l}45-\mathrm{ft} \\
\text { Containers }\end{array}$ & Other \\
\hline 75 & Nickel \& Articles Thereof & 1370 & 250 & 5 & 0 \\
\hline 76 & Aluminum \& Articles Thereof & 24,911 & 38,678 & 3021 & 909 \\
\hline 77 & Not Applicable & & & & \\
\hline 78 & Lead \& Articles Thereof & 1663 & 76 & 0 & 0 \\
\hline 79 & Zinc \& Articles Thereof & 811 & 596 & 16 & 0 \\
\hline 80 & Tin \& Articles Thereof & 1707 & 2034 & 119 & 2 \\
\hline 81 & Base Metals NESOI, Cermets, Articles, etc. & 6447 & 3558 & 661 & 207 \\
\hline 82 & Tools, Spoons \& Forks of Base Metal & 15,628 & 36,107 & 1582 & 12 \\
\hline 83 & Miscellaneous Articles of Base Metal & 25,762 & 42,969 & 1365 & 23 \\
\hline 84 & $\begin{array}{l}\text { Nuclear Reactors, Boilers, Machinery \& } \\
\text { Mechanical Appliances, Computers }\end{array}$ & 111,030 & 425,957 & 10,876 & 518 \\
\hline 85 & $\begin{array}{l}\text { Electrical Machinery \& Equipment \& Parts, } \\
\text { Telecommunications Equipment, Sound } \\
\text { Recorders, Televisions }\end{array}$ & 63,933 & 375,454 & 11,519 & 596 \\
\hline 86 & $\begin{array}{l}\text { Railway or Tramway Locomotives, Rolling Stock, } \\
\text { Track Fixtures \& Fittings, Signals }\end{array}$ & 8436 & 6741 & 2679 & 1027 \\
\hline 87 & $\begin{array}{l}\text { Vehicles Other Than Railway or Tramway } \\
\text { Rolling Stock }\end{array}$ & 71,218 & 282,245 & 9583 & 936 \\
\hline 88 & Aircraft, Spacecraft \& Parts Thereof & 570 & 2118 & 97 & 2 \\
\hline 89 & Ships, Boats \& Floating Structures & 741 & 2130 & 25 & 0 \\
\hline 90 & $\begin{array}{l}\text { Optical, Photographic, Cinematographic, } \\
\text { Measuring, Checking, Precision, Medical or } \\
\text { Surgical Instruements \& Accessories }\end{array}$ & 10,437 & 50,093 & 4898 & 1573 \\
\hline 91 & Clocks, Watches \& Parts Thereof & 684 & 4905 & 566 & 5 \\
\hline 92 & Musical Instruements, Parts \& Accessories & 1566 & 8786 & 478 & 1 \\
\hline 93 & Arms \& Ammunition, Parts \& Accessories & 1068 & 1109 & 8 & 1 \\
\hline 94 & $\begin{array}{l}\text { Furniture, Bedding, Cushions, Lamps \& Lighting } \\
\text { Fittings NESOI, Illuminated Signs, Nameplates \& } \\
\text { the Like, Prefabricated Buildings }\end{array}$ & 31,576 & 816,169 & 38,074 & 174 \\
\hline 95 & $\begin{array}{l}\text { Toys, Games \& Sports Equipment, Parts \& } \\
\text { Accessories }\end{array}$ & 25,360 & 255,781 & 33,013 & 1322 \\
\hline 96 & Miscellaneous Manufactured Articles & 3682 & 20,819 & 1325 & 142 \\
\hline 97 & Works of Art, Collectors' Pieces, Antiques & 766 & 4113 & 268 & 1 \\
\hline
\end{tabular}


PNNL-21088

\section{Appendix C: List of Shipping Container Distribution Based on 2-Digit Harmonized System Commodity Codes for IMCCs from Singapore}

This appendix includes the list of the 2-digit Harmonized System commodity codes and their associated number of containers shipped from Singapore to the US in 2006. Containers sized 20, 40, and $45 \mathrm{ft}$ are listed separately. Incorporated is a brief description for each 2-digit commodity code. 
PNNL-21088

\begin{tabular}{|c|c|c|c|c|}
\hline HS Code & Description & $\begin{array}{c}20-\mathrm{ft} \\
\text { Containers }\end{array}$ & $\begin{array}{c}40-\mathrm{ft} \\
\text { Containers }\end{array}$ & $\begin{array}{c}45-\mathrm{ft} \\
\text { Containers }\end{array}$ \\
\hline 0 & Household Goods & 1513 & 6981 & 475 \\
\hline 1 & Live Animals & 0 & 0 & 0 \\
\hline 2 & Meat \& Edible Meat Offal & 232 & 222 & 0 \\
\hline 3 & Fish \& Crustaceans & 637 & 7146 & 0 \\
\hline 4 & Dairy, Eggs, Honey \& Edible Products & 243 & 11 & 0 \\
\hline 5 & Products of Animal Origin & 2 & 11 & 0 \\
\hline 6 & Live Trees \& Other Plants & 16 & 294 & 21 \\
\hline 7 & Edible Vegetables & 97 & 104 & 0 \\
\hline 8 & Edible Fruits \& Nuts, Peel of Citrus/Melons & 1036 & 404 & 3 \\
\hline 9 & Coffee, Tea, Mate \& Spices & 5081 & 384 & 1 \\
\hline 10 & Cereals & 3048 & 9 & 0 \\
\hline 11 & Milling Industry Products & 84 & 22 & 0 \\
\hline 12 & Oil Seeds, Miscellaneous Grains, Medicinal Plants \& Straw & 131 & 195 & 0 \\
\hline 13 & Lac, Gum, Resins, etc. & 107 & 29 & 0 \\
\hline 14 & Vegetable Pailting Materials & 12 & 32 & 1 \\
\hline 15 & Animal or Vegetable Fats, Oils \& Waxes & 589 & 169 & 0 \\
\hline 16 & Edible Preparations of Meat, Fish Crustaceans, etc. & 1273 & 384 & 0 \\
\hline 17 & Sugars \& Sugar Confectionery & 65 & 52 & 0 \\
\hline 18 & Cocoa \& Cocoa Preparations & 736 & 259 & 0 \\
\hline 19 & Preparations of Cereal, Flour, Starch, or Milk & 74 & 598 & 0 \\
\hline 20 & Preparations of Vegetables, Fruits, Nuts, etc. & 3602 & 390 & 0 \\
\hline 21 & Miscellaneous Edible Preparations & 731 & 339 & 3 \\
\hline 22 & Beverages, Spirits \& Vinegar & 209 & 217 & 0 \\
\hline 23 & Residues from Food Industries \& Animal Feed & 61 & 398 & 0 \\
\hline 24 & Tobacco \& Manufactured Tobacco Substitues & 5 & 103 & 0 \\
\hline 25 & Salt, Sulphur, Earth \& Stone, Lime \& Cement & 1890 & 44 & 0 \\
\hline 26 & Ores Slag \& Ash & 196 & 0 & 0 \\
\hline
\end{tabular}


PNNL-21088

\begin{tabular}{|c|c|c|c|c|}
\hline HS Code & Description & $\begin{array}{c}20-\mathrm{ft} \\
\text { Containers }\end{array}$ & $\begin{array}{c}40-\mathrm{ft} \\
\text { Containers }\end{array}$ & $\begin{array}{c}45-\mathrm{ft} \\
\text { Containers }\end{array}$ \\
\hline 27 & Mineral Fuels, Oils, Waxes \& Bituminous Substitutes & 193 & 23 & 0 \\
\hline 28 & $\begin{array}{l}\text { Inorganic Chemicals, Organic/Inorganic Compounds of } \\
\text { Precious Metals, Isotopes }\end{array}$ & 722 & 158 & 0 \\
\hline 29 & Organic Chemicals & 1251 & 311 & 0 \\
\hline 30 & Pharmaceutical Products & 52 & 68 & 3 \\
\hline 31 & Fertilizers & 6 & 9 & 0 \\
\hline 32 & $\begin{array}{l}\text { Tanning or Dyeing Extracts, Dyes, Pigments, Paints \& } \\
\text { Varnishes, Putty \& Inks }\end{array}$ & 67 & 92 & 3 \\
\hline 33 & $\begin{array}{l}\text { Oils \& Resinoids, Perfumery, Cosmetic or Toilet } \\
\text { Preparations }\end{array}$ & 181 & 138 & 0 \\
\hline 34 & $\begin{array}{l}\text { Soaps, Waxes, Scouring Products, Candles, Modeling } \\
\text { Pastes, Dental Waxes }\end{array}$ & 124 & 243 & 6 \\
\hline 35 & Albuminoidal Substitutes, Starches, Glues, Enzymes & 42 & 24 & 0 \\
\hline 36 & Explosives, Matches, Pyrotechnic Products & 2 & 13 & 0 \\
\hline 37 & Photographic or Cinematographic Goods & 13 & 164 & 0 \\
\hline 38 & Miscellaneous Chemical Products & 373 & 368 & 0 \\
\hline 39 & Plastics \& Articles Thereof & 6675 & 3070 & 182 \\
\hline 40 & Rubbers \& Articles Thereof & 5148 & 7395 & 1832 \\
\hline 41 & Raw Hides, Skins \& Leather & 15 & 14 & 1 \\
\hline 42 & $\begin{array}{l}\text { Articles or Leather, Saddlery \& Harness, Travel Goods, } \\
\text { Handbags, Articles of Gut }\end{array}$ & 358 & 666 & 29 \\
\hline 43 & Furskins \& Artificial Fur & 11 & 13 & 0 \\
\hline 44 & Wood \& Articles of Wood, Wood Charcoal & 1476 & 3411 & 161 \\
\hline 45 & Cork \& Articles of Cork & 1 & 1 & 0 \\
\hline 46 & $\begin{array}{l}\text { Manufactures of Straw, Esparto, or Other Plaiting } \\
\text { Materials, Basketware \& Wickerwork }\end{array}$ & 68 & 382 & 28 \\
\hline 47 & Pulp of Wood, Waste $\&$ Scrap of Paper & 6 & 129 & 0 \\
\hline 48 & Paper \& Paperboard, Articles of Paper Pulp & 618 & 4044 & 8 \\
\hline
\end{tabular}


PNNL-21088

\begin{tabular}{|l|l|} 
HS Code & \multicolumn{1}{c|}{ Description } \\
\hline 49 & $\begin{array}{l}\text { Printed Books, Newspapers, Pictures, Manuscripts, } \\
\text { Typescripts \& Plans }\end{array}$ \\
\hline
\end{tabular}

50 Silk, Including Yarns \& Woven Fabrics Thereof

51

Wool \& Fine or Coarse Animal Hair, Including Yarns \& Woven Fabrics Thereof

52 Cotton, including Yarns \& Woven Fabrics Thereof

\section{3}

54 Man-Made Filaments, Including Yarns \& Woven etc.

55

56

57

58 Special Woven Fabrics, Tufted Textiles, Lace

59

$60 \quad$ Knitted or Crocheted Fabrics

61 Articles of Apparel \& Clothing Accessories - Knitted or Crocheted

62

Articles of Apparel \& Clothing Accessories - Not Knitted or Crocheted

\section{3}

Made-Up Textile Articles NESOI, Needlecraft Set, Worn Clothing, Rags

64

65

Footwear, Gaiters \& the Like

Headgear \& Other Parts

Umbrellas, Sun Umbrellas, Walking-Sticks, Whips, RidingCrops \& Parts

\begin{tabular}{|r|r|}
\hline $\begin{array}{c}\text { 20-ft } \\
\text { Containers }\end{array}$ & $\begin{array}{c}\text { 40-ft } \\
\text { Containers }\end{array}$ \\
\hline 388 & 277 \\
\hline
\end{tabular}

45-ft Containers

3

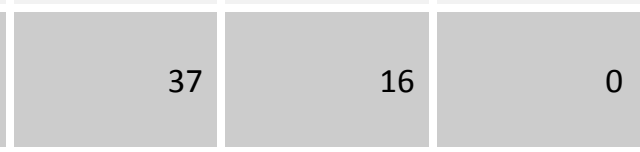

314

2040

37

\begin{tabular}{r|r|r|}
\hline 83 & 255 & 0 \\
\hline 117 & 753 & 12 \\
\hline 7 & 213 & 0 \\
\hline
\end{tabular}

76

234

5

219

695

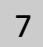

34

96

3

\begin{tabular}{|c|c|c|}
\hline 30 & 199 & 0 \\
\hline 40 & 253 & 16 \\
\hline 1416 & 5640 & 918 \\
\hline
\end{tabular}

4126

18,060

1698

\begin{tabular}{|r|r|r|}
\hline 638 & 3637 & 44 \\
\hline 761 & 2260 & 317 \\
\hline 112 & 166 & 20 \\
\hline
\end{tabular}

3

46

0 
PNNL-21088

\begin{tabular}{|c|c|c|c|c|}
\hline HS Code & Description & $\begin{array}{c}20-\mathrm{ft} \\
\text { Containers }\end{array}$ & $\begin{array}{c}40-\mathrm{ft} \\
\text { Containers }\end{array}$ & $\begin{array}{c}45-\mathrm{ft} \\
\text { Containers }\end{array}$ \\
\hline 67 & $\begin{array}{l}\text { Prepared Feathers, Human Hair \& Articles Thereof, } \\
\text { Artificial Flowers }\end{array}$ & 46 & 92 & 1 \\
\hline 68 & $\begin{array}{l}\text { Articles of Stone, Plaster, Cement, Asbestos, Mica, or } \\
\text { Similar Materials }\end{array}$ & 2869 & 36 & 0 \\
\hline 69 & Ceramic Products & 1972 & 2854 & 39 \\
\hline 70 & Glass \& Glassware & 165 & 814 & 19 \\
\hline 71 & Pearls, Stones, Precious Metals, Imitation Jewelery, Coins & 5 & 5 & 0 \\
\hline 72 & Iron \& Steel & 626 & 99 & 1 \\
\hline 73 & Articles of Iron or Steel & 3971 & 1636 & 68 \\
\hline 74 & Copper \& Articles Thereof & 21 & 35 & 1 \\
\hline 75 & Nickel \& Articles Thereof & 57 & 0 & 0 \\
\hline 76 & Aluminum \& Articles Thereof & 1584 & 360 & 101 \\
\hline 77 & Not Applicable & & & \\
\hline 78 & Lead \& Articles Thereof & 0 & 0 & 0 \\
\hline 79 & Zinc \& Articles Thereof & 8 & 0 & 0 \\
\hline 80 & Tin \& Articles Thereof & 25 & 5 & 0 \\
\hline 81 & Base Metals NESOI, Cermets, Articles, etc. & 132 & 3 & 0 \\
\hline 82 & Tools, Spoons \& Forks of Base Metal & 391 & 221 & 0 \\
\hline 83 & Miscellaneous Articles of Base Metal & 1096 & 1463 & 16 \\
\hline 84 & $\begin{array}{l}\text { Nuclear Reactors, Boilers, Machinery \& Mechanical } \\
\text { Appliances, Computers }\end{array}$ & 3861 & 7820 & 21 \\
\hline 85 & $\begin{array}{l}\text { Electrical Machinery \& Equipment \& Parts, } \\
\text { Telecommunications Equipment, Sound Recorders, } \\
\text { Televisions }\end{array}$ & 3738 & 27,375 & 834 \\
\hline 86 & $\begin{array}{l}\text { Railway or Tramway Locomotives, Rolling Stock, Track } \\
\text { Fixtures \& Fittings, Signals }\end{array}$ & 149 & 103 & 2 \\
\hline 87 & Vehicles Other Than Railway or Tramway Rolling Stock & 1208 & 2748 & 9 \\
\hline 88 & Aircraft, Spacecraft \& Parts Thereof & 12 & 34 & 0 \\
\hline
\end{tabular}


PNNL-21088

\begin{tabular}{|c|c|c|c|c|}
\hline HS Code & Description & $\begin{array}{c}\text { 20-ft } \\
\text { Containers }\end{array}$ & $\begin{array}{c}\text { 40-ft } \\
\text { Containers }\end{array}$ & $\begin{array}{c}\text { 45-ft } \\
\text { Containers }\end{array}$ \\
\hline 89 & Ships, Boats \& Floating Structures & 19 & 46 & 1 \\
\hline 90 & $\begin{array}{l}\text { Optical, Photographic, Cinematographic, Measuring, } \\
\text { Checking, Precision, Medical or Surgical Instruements \& } \\
\text { Accessories }\end{array}$ & 222 & 1672 & 460 \\
\hline 91 & Clocks, Watches \& Parts Thereof & 1 & 19 & 0 \\
\hline 92 & Musical Instruements, Parts \& Accessories & 79 & 944 & 56 \\
\hline 93 & Arms \& Ammunition, Parts \& Accessories & 0 & 1 & 0 \\
\hline 94 & $\begin{array}{l}\text { Furniture, Bedding, Cushions, Lamps \& Lighting Fittings } \\
\text { NESOI, Illuminated Signs, Nameplates \& the Like, } \\
\text { Prefabricated Buildings }\end{array}$ & 808 & 20,893 & 1511 \\
\hline 95 & Toys, Games \& Sports Equipment, Parts \& Accessories & 320 & 1910 & 129 \\
\hline 96 & Miscellaneous Manufactured Articles & 194 & 494 & 0 \\
\hline 97 & Works of Art, Collectors' Pieces, Antiques & 16 & 208 & 1 \\
\hline
\end{tabular}


PNNL-21088

\section{Appendix D: List of Ceramic Materials Shipped to the United States}

This appendix includes the list of the 4- and 6-digit Harmonized System commodity codes and their associated number of containers for ceramic commodities shipped to the US in 2006. Containers sized 20, 40, and $45 \mathrm{ft}$ are listed separately. Incorporated is a brief description for each commodity code. 
PNNL-21088

\begin{tabular}{|c|c|c|c|c|}
\hline HS Code & Description & $\begin{array}{l}20-\mathrm{ft} \\
\text { Containers }\end{array}$ & $\begin{array}{c}40-\mathrm{ft} \\
\text { Containers }\end{array}$ & $\begin{array}{l}45-\mathrm{ft} \\
\text { Containers }\end{array}$ \\
\hline 690100 & $\begin{array}{l}\text { Bricks, blocks, tiles and other ceramic goods of siliceous } \\
\text { fossil meals (for example, kieselguhr, tripolite or } \\
\text { diatomite) or of similar siliceous earths }\end{array}$ & & 33 & \\
\hline 6902 & $\begin{array}{l}\text { Refractory bricks \& other refr ceramic const art nesoi (not } \\
\text { elsewhere specified or included) }\end{array}$ & & 1 & \\
\hline 690210 & $\begin{array}{l}\text { Refractory bricks, blocks, tiles, Containing by weight, } \\
\text { singly or together, more than } 50 \text { percent of the elements } \\
\text { magnesium, calcium, or chromium, expressed as } \mathrm{MgO} \text {, } \\
\mathrm{CaO} \text { or } \mathrm{Cr} 2 \mathrm{O} 3\end{array}$ & 242 & 28 & \\
\hline 690220 & $\begin{array}{l}\text { Refractory bricks, blocks, tiles Containing by weight more } \\
\text { than } 50 \text { percent of alumina (Al2O3), of silica ( } \mathrm{SiO} 2 \text { ) or of a } \\
\text { mixture or compound of these products }\end{array}$ & 31 & 5 & \\
\hline 690290 & Other Refractory bricks, blocks, tiles & 2468 & 354 & 1 \\
\hline 6903 & Refractory ceramic goods, retorts, tubes etc nesoi & 2 & 1 & \\
\hline 690310 & $\begin{array}{l}\text { Refractory ceramic goods, Containing by weight more } \\
\text { than } 50 \text { percent of graphite or other forms of carbon or of } \\
\text { a mixture of these products }\end{array}$ & 12 & 4 & \\
\hline 690320 & $\begin{array}{l}\text { Refractory ceramic goods, Containing by weight more } \\
\text { than } 50 \text { percent of alumina (Al2O3) or of a mixture or } \\
\text { compound of alumina and of silica ( } \mathrm{SiO} 2 \text { ) }\end{array}$ & 105 & 11 & \\
\hline 690390 & $\begin{array}{l}\text { Other refractory ceramic goods, Containing by weight } \\
\text { more than } 50 \text { percent of alumina ( } \mathrm{Al} 2 \mathrm{O} 3 \text { ) or of a mixture } \\
\text { or compound of alumina and of silica ( } \mathrm{SiO2} \text { ) }\end{array}$ & 1194 & 299 & 8 \\
\hline 690410 & Ceramic Building bricks & 32 & 24 & \\
\hline 690490 & $\begin{array}{l}\text { Ceramic Flooring Blocks, Support or Filler Tiles and the } \\
\text { Like }\end{array}$ & 24 & & \\
\hline 6905 & Roofing tiles, chimney pots, cowls, chimney liners etc & & 1 & \\
\hline 690510 & Ceramic Roofing tiles & 1510 & 688 & \\
\hline 690600 & Ceramic pipes, conduits, guttering and pipe fittings & 3 & & \\
\hline 690790 & Unglazed Ceramic Flags flagstone tile & 46,818 & 1466 & 12 \\
\hline 6908 & Glazed ceramic flags \& paving, hearth tiles, etc & 1 & & \\
\hline 690810 & Glazed Ceramic Tiles, Cubes and Similar Articles & 561 & 171 & 27 \\
\hline 690890 & Glazed Ceramic Flags flagstone tile & 21,556 & 566 & \\
\hline 6909 & Ceramic lab etc wares, aggregate tubs etc $\&$ packing art & 2 & 2 & \\
\hline
\end{tabular}


PNNL-21088

\begin{tabular}{|c|c|c|c|c|}
\hline HS Code & Description & $\begin{array}{c}\text { 20-ft } \\
\text { Containers }\end{array}$ & $\begin{array}{c}40-\mathrm{ft} \\
\text { Containers }\end{array}$ & $\begin{array}{l}\text { 45-ft } \\
\text { Containers }\end{array}$ \\
\hline 690911 & $\begin{array}{l}\text { Ceramic wares for laboratory, chemical or other technical } \\
\text { uses, Of porcelain or china }\end{array}$ & 20 & 1 & \\
\hline 690919 & $\begin{array}{l}\text { Other Ceramic wares for laboratory, chemical or other } \\
\text { technical uses }\end{array}$ & 15 & 17 & \\
\hline 691010 & $\begin{array}{l}\text { Ceramic sinks, washbasins, washbasin pedestals, baths, } \\
\text { similar sanitary fixtures, Of porcelain or china }\end{array}$ & 9 & 610 & \\
\hline 691090 & Other sanitary fixtures & 1133 & 23,592 & 355 \\
\hline 6911 & Ceramic tableware etc. of porcelain or china & 1 & & \\
\hline 691110 & Tableware and kitchenware, of porcelain or china & 495 & 1136 & 31 \\
\hline 691190 & $\begin{array}{l}\text { Other Household Articles and Toilet Articles, of porcelain } \\
\text { or china }\end{array}$ & 2 & 48 & 2 \\
\hline 6912 & Ceramic tableware, kitchenware etc, earthenware etc & & 2 & 2 \\
\hline 691200 & $\begin{array}{l}\text { Ceramic tableware, kitchenware, other household articles } \\
\text { and toilet articles, other than of porcelain or china: } \\
\text { Tableware and kitchenware }\end{array}$ & 1947 & 16,313 & 881 \\
\hline 6913 & Statuettes and other ornamental ceramic articles & 51 & 418 & 65 \\
\hline 691310 & $\begin{array}{l}\text { Statuettes and other ornamental ceramic articles, Of } \\
\text { porcelain or china }\end{array}$ & 175 & 1323 & 134 \\
\hline 691390 & Other Statuettes and other ornamental ceramic articles & 310 & 4248 & 462 \\
\hline 6914 & Ceramic articles nesoi & 31 & & \\
\hline 691410 & Other ceramic articles, Of porcelain or china & 1390 & 4073 & 298 \\
\hline 691490 & Other ceramic articles & 3910 & 14,427 & 701 \\
\hline
\end{tabular}




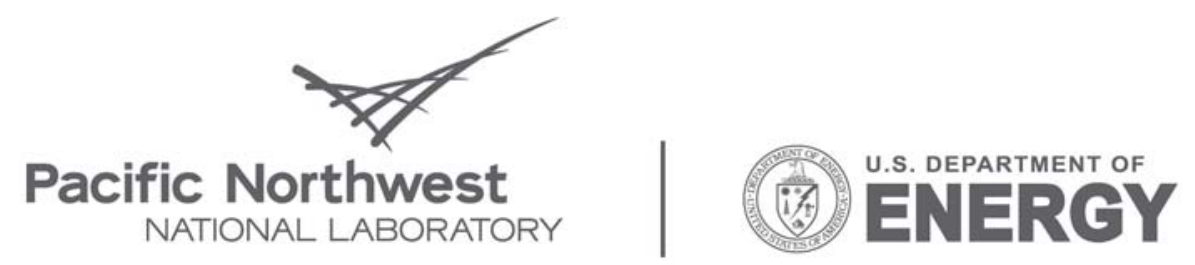

Proudly Operated by Battelle Since 1965

902 Battelle Boulevard

P.O. Box 999

Richland, WA 99352

1-888-375-PNNL (7665)

www.pnl.gov 